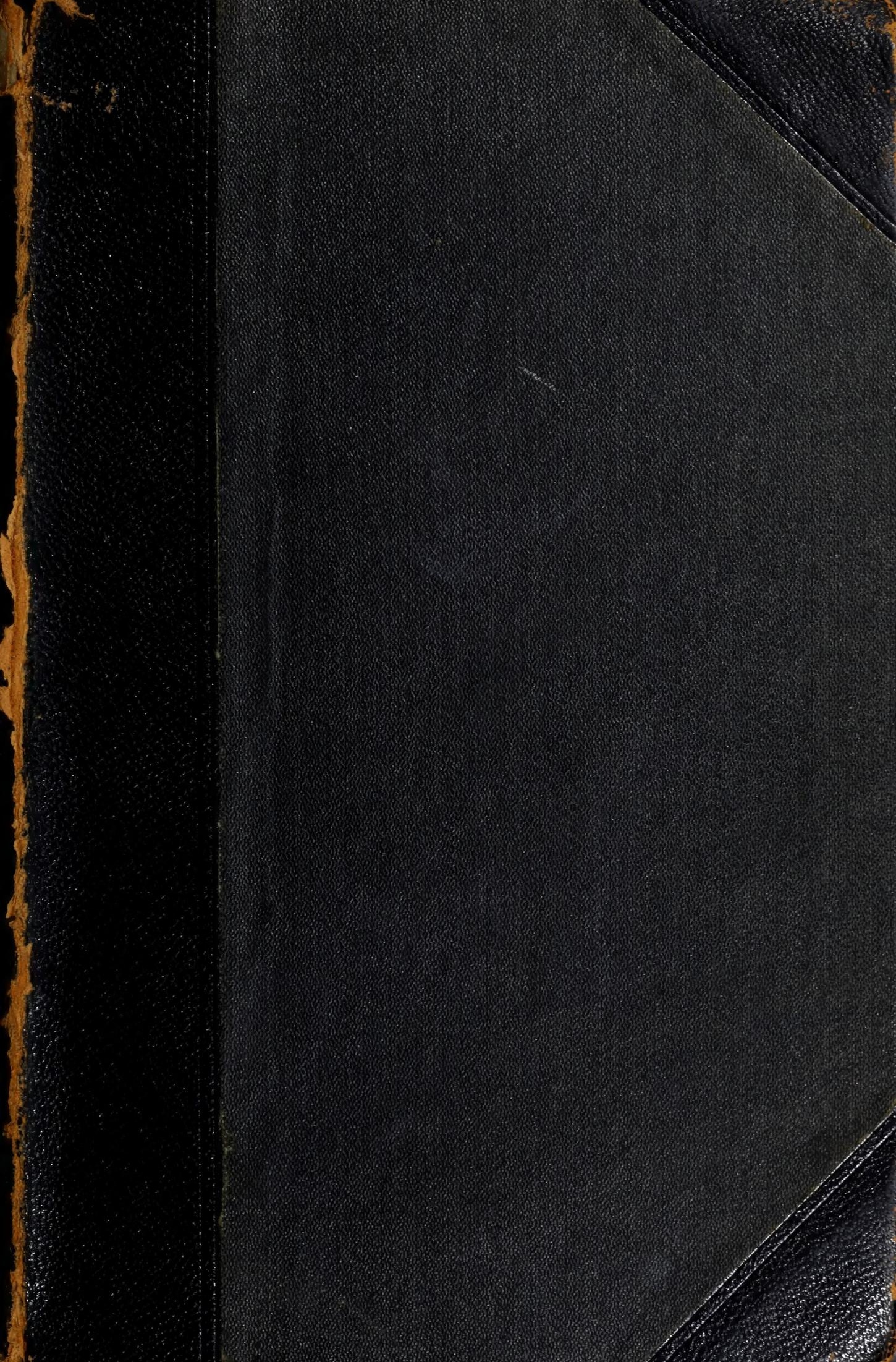





\section{Historic, archived document}

Do not assume content reflects current scientific knowledge, policies, or practices. 


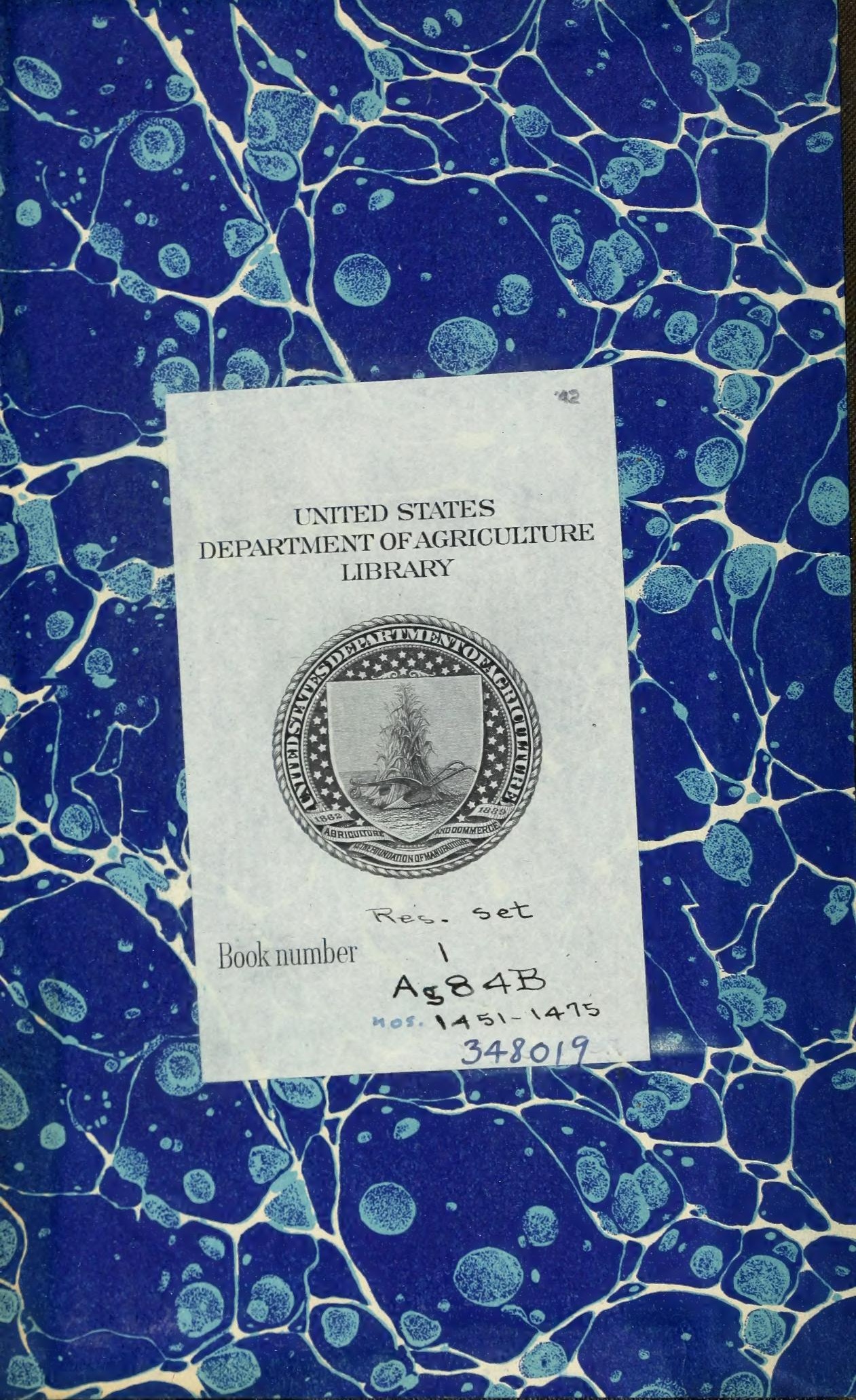




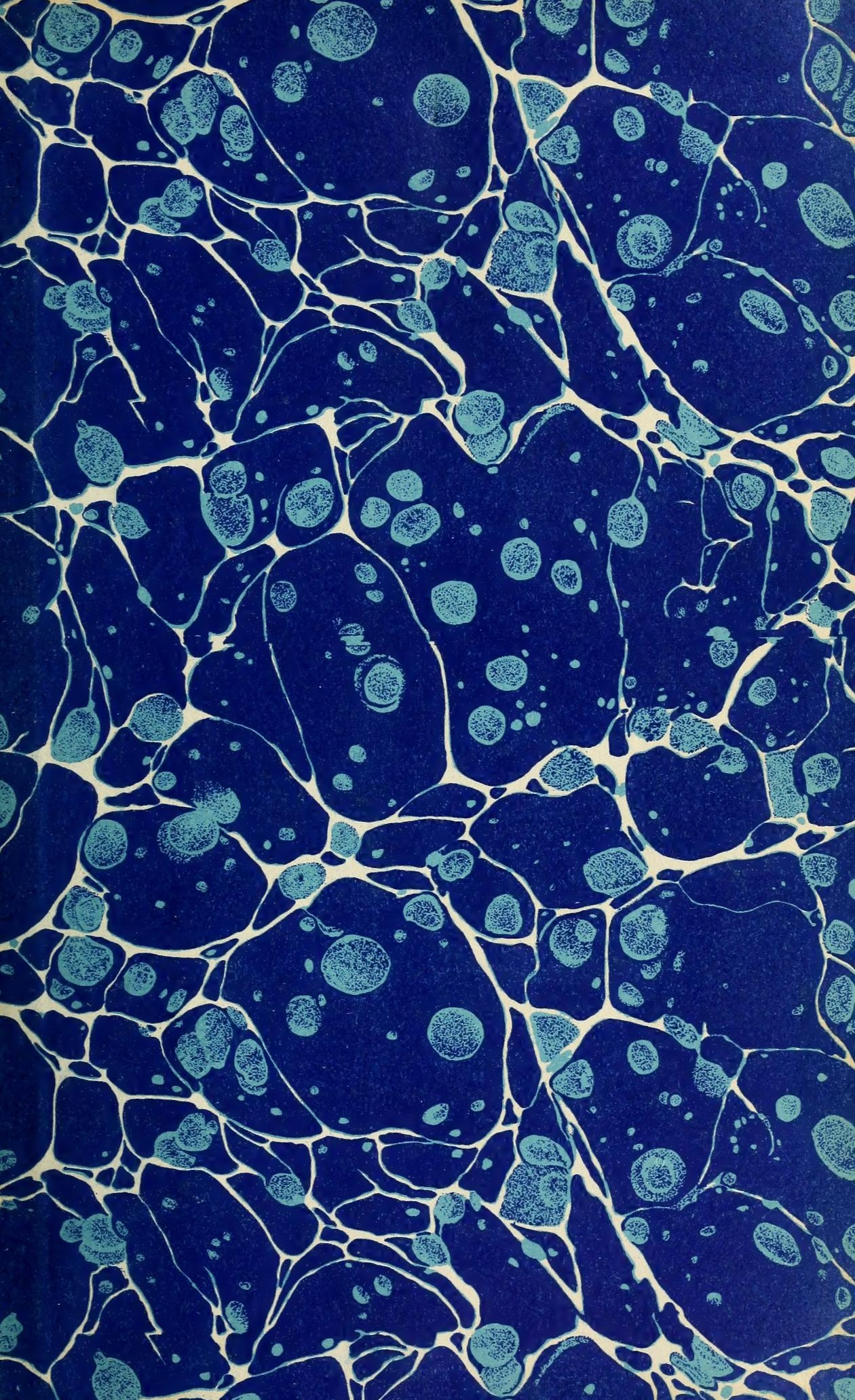







\section{UNITED STATES DEPARTMENT OF AGRICULTURE}

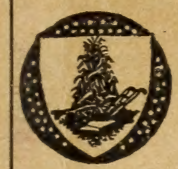

In Cooperation with the University of Wisconsin and the Wisconsin Department of Agriculture

\section{DEPARTMENT BULLETIN №. 1451}

Washington, D. C.

$\nabla$

December, 1926

METHODS OF ERADICATING THE COMMON BARBERRY (BERBERIS VULGARIS L.)

By

NOEL F. THOMPSON, Associale Pathologist, Ofice of Cereal Crops and Diseases, Burean of Plant Industry, and W. W. ROBBINS, Associate Professor of Botany, University of California, Collaborator, and formerly Botanist, Office of Cereal

Crops and Diseases, Burean of Plant lndustry

\section{CONTENTS}

Pago

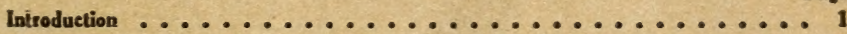

The Common Barberry Plant ................... 2

Mechanical Methode of Eradication ................... 5

Chemical Methods of Eradiention ..................... 10

General Summary ........................ 43

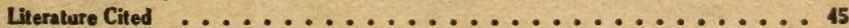





\section{UNITED STATES DEPARTMENT OF AGRICULTURE}

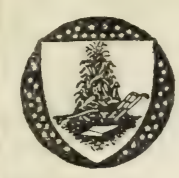

In Cooperation with the

University of Wisconsin and the Wisconsin Department

of Agriculture

DEPARTMENT BULLETIN NNo. 1451

Washington, D. C.

December, 1926

\section{METHODS OF ERADICATING THE COMMON BARBERRY (BERBERIS VULGARIS L.)}

By Noen F. Thompson, Associate Pathologist, Office of Cereal Crops and Diseases, Bureau of Plant Industry, and W. W. RoBbins, Associate Professor of Botany, University of California, Collaborator, and formerly Botanist, Office of Cereal Crops and Diseases, Bureau of Plant Industry

\section{CONTENTS}

\begin{tabular}{r|cc} 
Page & Page \\
1 & Chemical methods of eradication- & \\
$\mathbf{2}$ & Continued. & \\
5 & Extent and location of experi- & \\
8 & ments & Chemicals used. \\
9 & Summary of chemicals studied.- & $\mathbf{4 1}$ \\
10 & General summary & 43 \\
11 & Literature cited. &
\end{tabular}

\section{INTRODUCTION}

The common barberry (Berberis vulgaris L.) has been very extensively planted in the United States. It is not native to America but was introduced mainly from Europe. Lind $(9)^{1}$ adduces considerable evidence that the bush came originally from the middle and western Asiatic mountains and still is found growing wild in the Himalayas. He states that the plant is mentioned in Hindu and Babylonian writings as early as $650 \mathrm{~B}$. C. It apparently was introduced into Europe about the seventh century by the Arabians after having been planted in Egypt and the Barbary States. It is possible that the name of the bush was derived from that of the latter country.

In Europe the barberry was extensively planted because of its medicinal properties. Later it came into use as a hedge plant, partly, no doubt, because of its sharp, persistent thorns. The juice of the berries has also found favor for making beverages and jellies.

The barberry evidently was brought to America by some of the very early settlers and was planted extensively in the New England States. Many later importations have been made, and because of the activity of nurserymen as well as of settlers in different parts of

1 Serial numbers in italic in parentheses refer to "Literature cited," page 45 . $4197-26-1$ 
the country it has been very generally distributed throughout the United States. Throughout the southern New England States and in New York and Pennsylvania especially it has become extensively naturalized and is found growing wild very generally. In the States bordering on the Great Lakes, wherever waste land was found, its naturalization was proceeding rapidly until checked by the barberryeradication campaign begun in 1918. In the Great Plains area it had not secured a strong foothold but nevertheless was planted extensively. In the Southern States it was not planted to any great extent. The optimum development of individual plants appears to have been reached in the States of the Great Lakes region in limestone or sandy soil. Had its spread not been checked in most of this area, it is difficult to imagine to what extent it might hare developed.

The part that the barberry plays in the life history of the black stem rust of grains and grasses is too well known to need repeating here. That the barberry is the principal if not the only local source of stem rust in the spring in the northern part of the United States is well known. Its eradication, especially in the northern graingrowing areas, had often been suggested, but it was not until 1918 that concerted action was possible. Acting on the suggestion of the United States Department of Agriculture, 13 of the North-Central States joined in a campaign to eradicate the common barberry and all other varieties known to harbor the rust. The campaign was organized under the direction of the United States Department of Agriculture, and a leader was placed in charge of the work in each State. Field men were employed to find and destroy the bushes. At first it was not thought necessary to keep very careful records of the exact locations of all bushes which were dug or otherwise removed, but the fallacy of this belief was evident when some of these locations were inspected the second year and an appalling number of sprouts was found. More careful digging was required, and an exact record of all locations was kept. The check for sprouts also was made a regular part of the work, but still large numbers of sprouts occurred, and even two or three diggings failed to eliminate all of them. It soon became apparent that not only must the work be done more thoroughly but that more certain means of killing barberry bushes must be devised. This was especially true in areas of escaped bushes.

In response to this demand the United States Department of Agriculture in 1921 started an intensive study of the common barberry with the object of ascertaining how the bush could be killed with a minimum of expense. The practical results of this study have been recorded in two circulars $(15,16)$ of the department. In the present bulletin is presented a discussion of results of digging barberries, together with details of all chemicals studied in the effort to find satisfactory chemical methods of eradication.

\section{THE COMMON BARBERRY PLANT}

The common barberry bush (pl. 1) usually is composed of a number of stalks which arise from below the surface of the ground and grow to a height of 6 to 10 feet with few, if any, large branches except near the ground line. There may be 20 to 30 of these shoots 
in a mature bush, and their upright, unbranched growth with erect, rigid tips is very characteristic. There are, however, many short, slender lateral branches. The leares are simple and have bristletoothed edges. This is one character which serres to distinguish the common barberry from the Japanese barberry, in which the leares have smooth edges. The leares normally grow in small groups or rosettes upon short spurs in the axils of stiff thorns, These thorns represent the leares of the elongated shoots. The lower leares on any shoot are usually typical, but the blades of the leaves are reduced in the later ones until only the stiff ribs are left as thorns. The number of points to a thorn is typically three, though there may be seven or more on the first ones produced and only one on those produced near the tip of the branch. They are arranged spirally on the branch, and the short, leafy spurs develop in their axils.

In the second and subsequent years the flowers and fruit may develop from these short spurs. The flowers are yellow and are arranged in racemes of 10 to 20 flowers each. The berries are bright red when ripe and contain two large seeds. They are very persistent, frequently remaining attached through the winter and even after the new leaves have developed in the spring. (Pl. 2.)

The bark of the barberry also is characteristic. On older shoots it is gray and stringy. An even more striking character for distinguishing barberries from other shrubs is the canary-yellow color of the inner bark and wood. This yellow color is present in the roots as well as in the shoots and serves to distinguish the roots of the barberry from other roots when the bush is being dug.

As the common barberry is an introduced ornamental shrub, it is most commonly found in ornamental plantings. It also occasionally has been used as a hedge plant or in the garden, where it is cultivated for the berries, which are edible. The bush grows readily from seed, consequently escaped bushes may be found in the vicinity of plantings. Such bushes thrive in the northern part of the United States along fence rows and in natural pastures and open wood lots. In the deep shade of thick woods it does not thrive, but in open places in well-drained soil, especially in soil that is alkaline in its reaction, it reaches its greatest development.

Most barberry bushes produce an abundance of fruit, and each berry normally contains two seeds. The berries are very persistent and, as has been said, may remain attached to the bush all winter. They do not seem to be the favorite food of any bird, and when other food is readily available they are scarcely touched by birds. During the winter, however, when other food becomes scarce, and especially during the early spring migration, many birds eat the berries of the barberry for the fleshy part of the fruit. The seeds seldom are destroyed by birds and may be regurgitated or may pass unharmed through the digestive tract. More than a dozen species of birds are known to eat the berries, and undoubtedly many others do so as occasion offers. Through this means barberry seeds may be distributed several miles from the parent bush (fig. 1 and pl. 3, B). Many seeds so distributed undoubtedly develop into mature bushes. which in turn may produce seed.

Cattle also take an active part in the distribution of the barberry. It is not generally relished by cattle, but occasionally an animal 
develops a liking for the leaves of the bush. Cattle also will browse on the ripe berries, and the seeds are deposited uninjured in the manure. (Pl. 3, A.) Many pastures have been found badly infested with barberry. In most of such cases adjoining pastures or wood lots contained but few barberry bushes.

These two agencies, birds and cattle, are the chief natural means of distributing escaped barberries in the United States, the birds serving to distribute the seed over an extensive area and the cattle intensively over more limited areas. Water, wind, and other natural agencies also serve to distribute the plant, but to a much more limited extent. Man also may distribute the bush unintentionally by carrying the seeds in mud sticking to shoes or in the use of the fruit for decorations.

Once the barberry has become established it is found to be very difficult to eradicate. This is because of the readiness with which

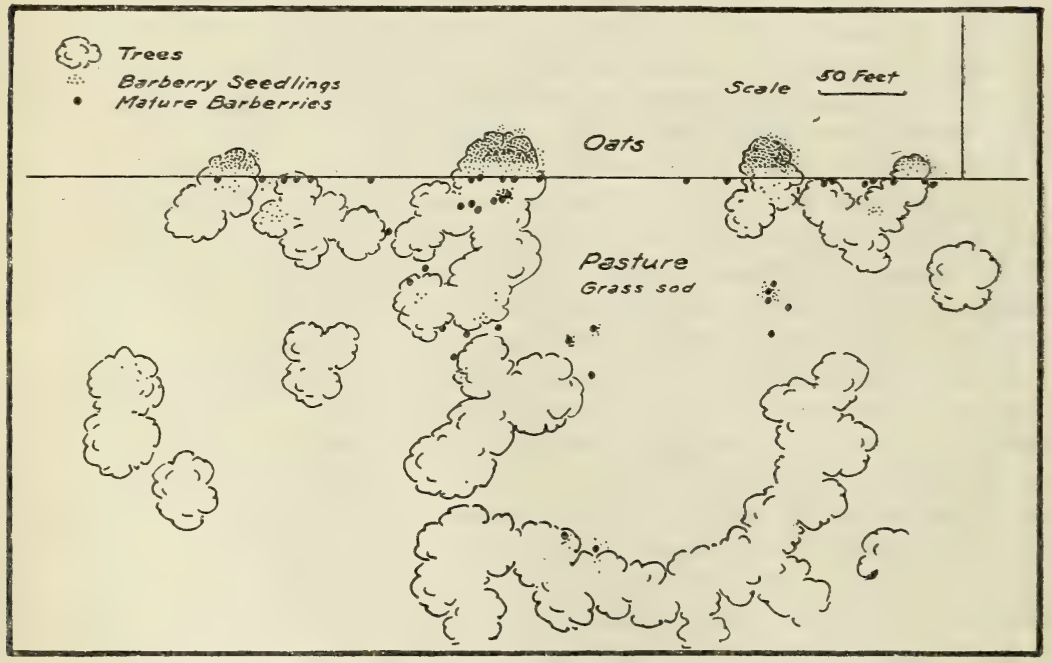

FIG. 1.-Distribution of barberry seedlings grown from seeds scattered by birds

sprouts develop from any of the underground portions of the bush. Small fragments of either the roots or rhizomes may grow and produce bushes. This makes a barberry very easy to propagate, but very difficult to kill.

In order to give a clear picture of the barberry and the difficulties involved in its eradication it is necessary to describe the development of a bush. A single shoot is sent up from the germinating seed. Ordinarily in the second or third year, but sometimes not until after four or five years, other shoots arise from near the base of this primary shoot either just above or below the surface of the ground (pl. 6, A). The primary shoot seldom grows to a great length and usually is slender and drooping, but the secondary shoots are large and erect. In this way the bush develops for several years. Meanwhile the root system has been developing. Immediately around the base of the crown is a thick mass of fine fibrous roots. Large lateral roots also develop (pl. 4, A). These parallel the surface of the 


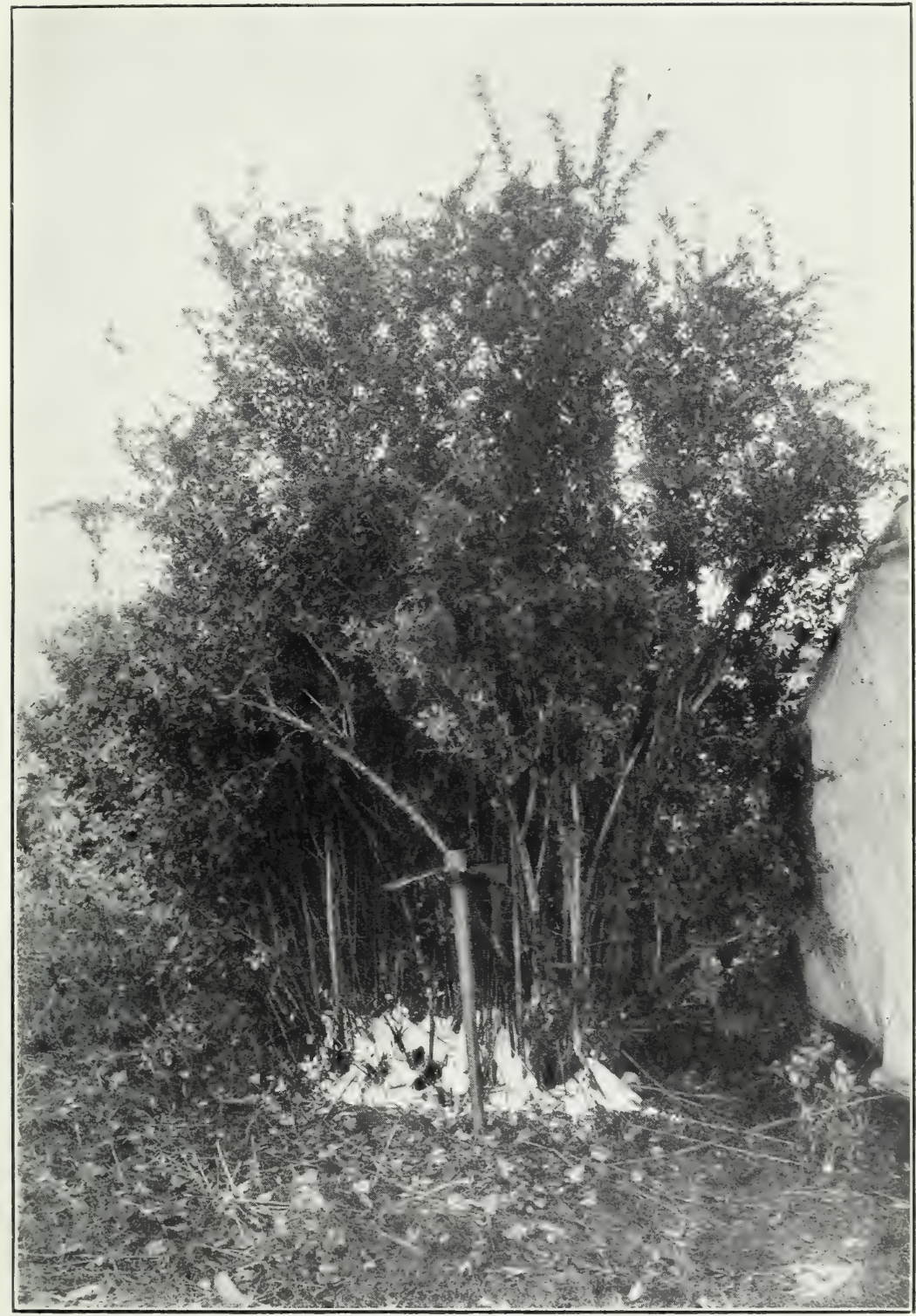

A Common Barberry Bush (Berberis Vulgaris L.) TREATEd WITH SALT 


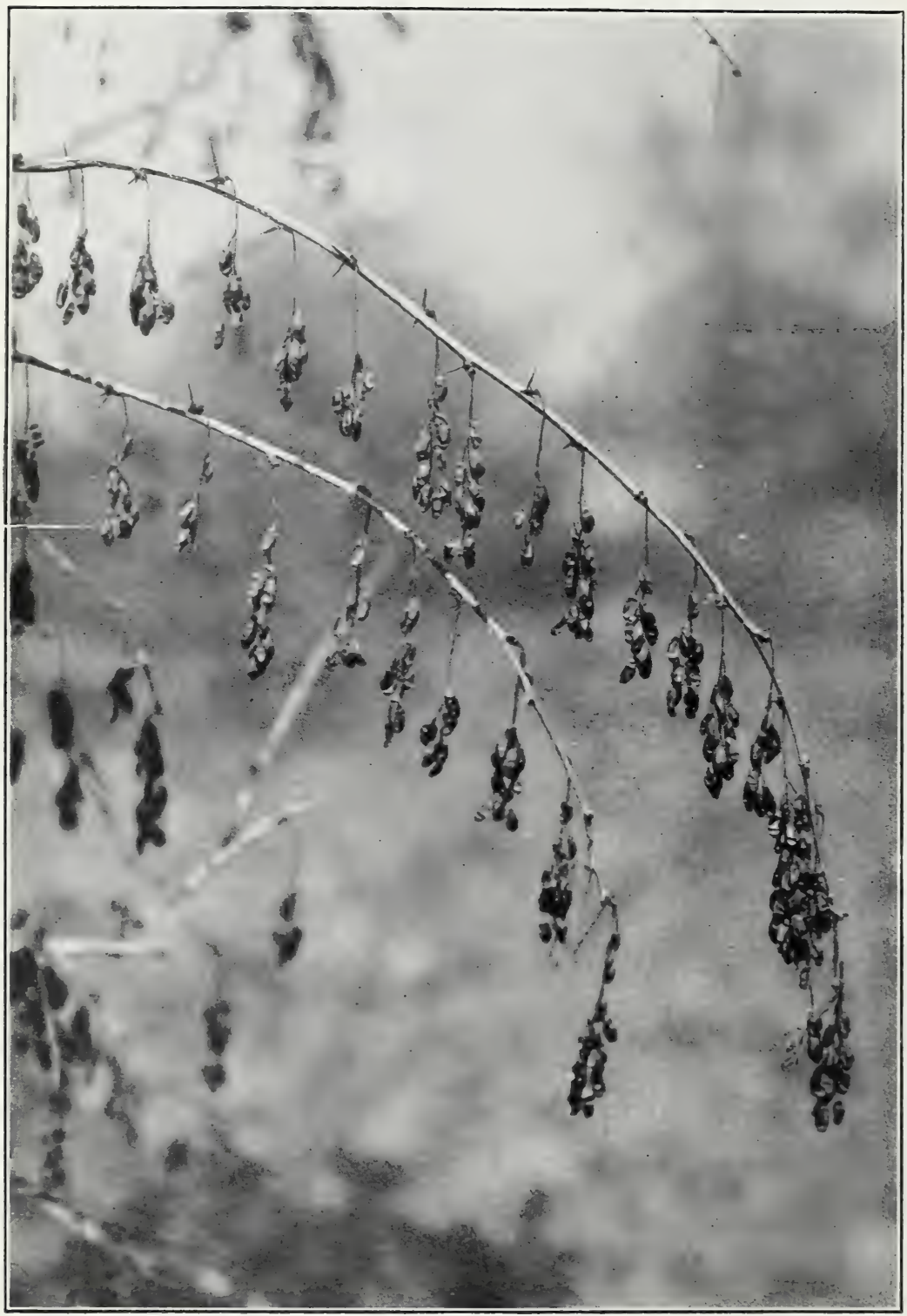

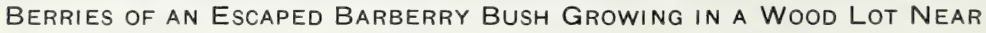
GURNEE, ILL.

On April 12, 1924, when this photograph was taken, large quantities of the previous year's berries still were attached to the bushes in the vicinity 

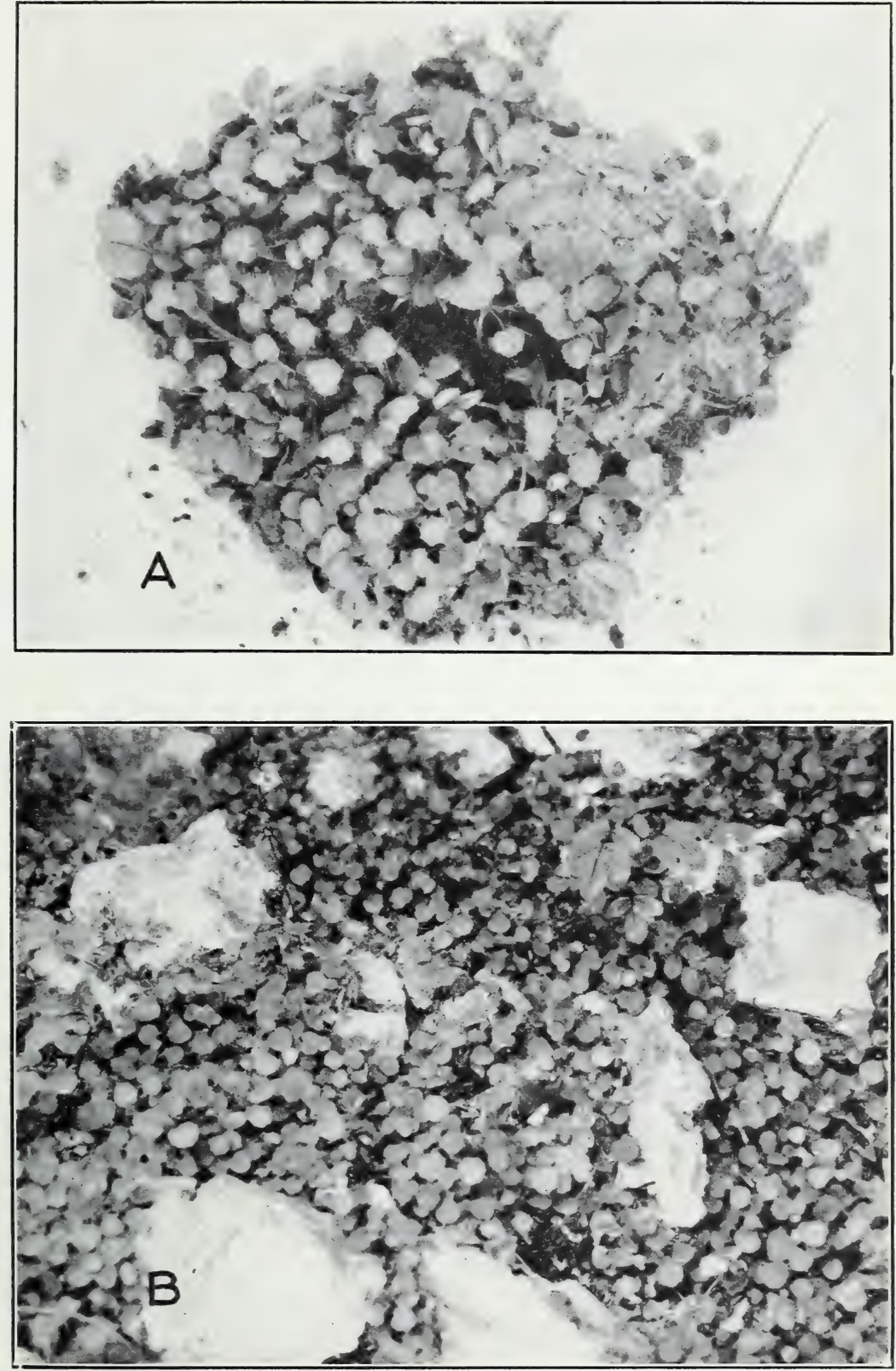

How Barberries Are Spread by ANimals and Birds

A. - Barberry seedlings growing in cow dung in a Connecticut pasture where there were many escaped barberries. No mature barberries were growing near the point where these

seedlings were found. Similar observations have been made several times in W isconsin

B.-Barberry seedlings among limestone fragments under a cliff in Dane County, Wis. The seeds probably were carried by birds from barberry bushes in the vicinity 

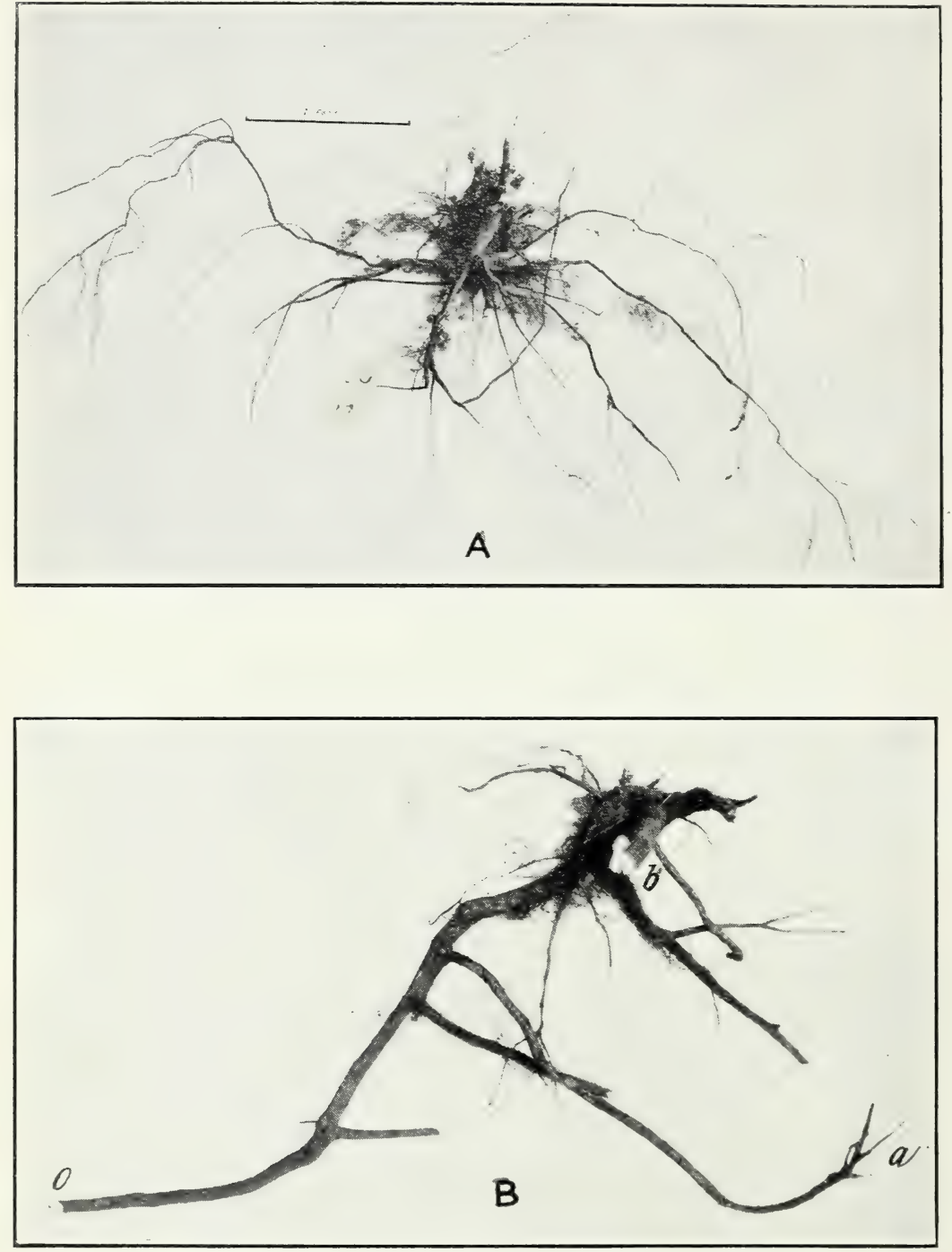

ROOTS AND RHIZOMES OF BARBERRY

A.-Root system of a small escaped barberry bush

B.-Rhizome from which two new shoots $(a$ and $b)$ have developed. This rhizome, also shown in Plate 5 , is smallest near its point of origin $(0)$ and bears fibrous roots near the base of the aerial shoots $(a$ and $b)$ 
ground and may lie from a few inches to a foot or more below it. They may become an inch or two in diameter near the bush and may be 10 to 15 feet long. These large lateral roots branch to some extent and produce numerous fibrous roots. They give the bush its chief mechanical support, but the intake of substances from the soil probably is confined largely to the fibrous roots near the crown. When barberries are dug most of the sprouts which may develop later arise from these long lateral roots. Ther'e is seldom a deep taproot.

As the bush grows, rhizomes are produced from the crown below the surface of the ground. They usually grow laterally a foot or two and only a few inches below the surface, then turn upward and produce aerial shoots (pl. 4, B, and pl. 5). They may develop from lateral roots, howerer, and also may grow downward 2 or 3 feet before turning upward. These rhizomes usually are devoid of roots until the aerial shoots develop, when a mass of fibrous roots forms immediately below the point of emergence. When this has occurred the rhizome may be severed between its origin and this new root development without injuring the new shoot. The rhizomes also may branch either before or subsequently to the emergence of the shoot.

By the methods just described the parent bush increases its size, forming a thick clump of shoots. Such clumps eventually may become a rod or more in diameter. Individual shoots may live 20 or even 30 years, but they eventually die and are replaced by new shoots. This habit makes it difficult or impossible to determine accurately the age of an old barberry bush.

\section{MECHANICAL METHODS OF ERADICATION}

The chief means of eradicating barberry bushes has been by digging. Even with the development of chemical methods which are cheaper, easier, and more effective, there are many bushes that must of necessity be dug because of the presence of other valuable plants or because of consideration of the action of a chemical on the soil. The grub hoe has proved itself the most valuable tool for this work. An axlike blade on one side is of use in cutting down the bush before digging is started where such a course is necessary. The broad, heavy hoe on the other side makes digging fairly easy.

In case the bush is small, one man usually can push it to one side while he loosens the crown with the grub hoe and raises the entire bush from the ground. With larger bushes, or those with spreading tops, it frequently is advantageous to have two men work together. One passes a rope around the bush 2 or 3 feet above the ground and pul's the shoots out of the way of the other, who, with a grub hoe, loosens the dirt around the crown of the bush and cuts the larger supporting roots. After working part way or entirely around the bush in this fashion it usually is easy to insert the blade of the grub hoe under the bush and pry the entire crown out of the ground while the other man pulls on the rope.

These operations must always be followed by the removal of root fragments from the hole and by tracing and removing all the supporting roots which were cut or broken off. If this is not done care- 
fully sprouts are almost sure to develop (pl. $7, \mathrm{~A}$ ), as the supporting roots run out to a considerable distance, often 10 or 12 feet, from the crown. Roots a foot or more under the surface of the ground rarely if ever send up sprouts, but those near the surface sprout readily when cut or disturbed by digging. Most of the supporting roots of the barberry lie within 6 inches or so of the surface of the soil. Some run deeper, however. In digging it is not safe to leave the latter, for they may run out a few feet from the crown at a depth of more than a foot and then rise again close to the surface. It can be seen readily that to dig a bush in the manner described requires considerable work, and yet this is exactly what must be done to prevent sprouting.

The use of a team or a tractor in removing the crown of a bush is often of great assistance. However, when a chain or a rope thrown around a bush at the ground level is drawn tight by a team or a tractor the shoots of the bush usually will bend over and allow the rope to slip off without disturbing the crown. The use of a crowbar in addition to the chain has been found very effective. The chain is looped around the base of the bush and the crowbar forced into the ground within the loop on the side opposite the team. The handle of the crowbar is pulled away from the bush by one man as the team is started by another. The result usually is the removal of the entire crown with some of the supporting roots. This operation must always be followed by a careful digging of the remaining root fragments, as previously described.

Dynamite has been used successfully at times. With a crowbar or an auger a hole is made from one side of the crown to a point about a foot and a half below its center. A quarter or a half stick of dynamite usually is sufficient to raise the bush from the ground. As with the other methods described, dynamiting always must be followed by grubbing to remove the remaining root fragments.

The method actually employed in any particular locality depends upon several factors, such as the number of bushes, their average size, the type of soil, the season, and the means available. Where many fair-sized bushes are to be dug, it is always desirable to obtain the aid of a team or a tractor. A large barberry bush, however, is frequently more than a team can pull without the aid of grubbing or a block and tackle. Even the average tractor frequently is stalled by a well-developed bush. In such cases the work can be done more easily when the ground is soft following prolonged rains. Sometimes the crown can be cut into several sections by cutting vertically through it with the ax end of the grub hoe, and so divided into parts small enough for handling by a stout team or a tractor.

Even with the expedient of cutting up the crown into segments, it sometimes is difficult to pull a bush when the ground is hard and dry. In such circumstances dynamite may be advisable. Dynamite also is of use in locations where traction can not be obtained, as on a steep bank.

In all these methods of eradicating barberries it is desirable to pile and burn the bushes and roots. There are two reasons for this. One is that it does away with any possibility of the bush taking root and growing where it is left. The other is that it destroys any seeds on the bushes. There have been many instances where bushes 
have taken root and continued to grow after being grubbed or pulled out. If they had been piled and burned there would have been no danger from this source. Many seedlings frequently develop where mature bushes have been dug. To reduce this source of new bushes the burning of the tops of the old ones which are bearing fruit is the easiest method.

The number of men that can be used for any particular job most economically will vary considerably. Since chemical means of eradi(ation have been developed most of the barberries that are dug occur singly or in relatively small numbers. For this work usually nothing is gained by employing more than two men. In many of the cases encountered one man alone is able to remove the bush quickly and satisfactorily. Howerer, as it is the policy of the barberry-eradication forces to hare two men trarel together in locating the barberries, and as these men usually eradicate the bushes if possible as soon as they are found. the minimum number usually employed on a particular job is two.

Before the introduction of chemicals escaped barberries were eradicated from several large areas by digging. A number of considerations influenced the size of the crew employed in these cases. When a team or a tractor was used to pull the bushes it was found desirable to have a sufficient number of men grubbing the roots so that the team or the tractor was never far ahead of the grubbers. If this balance was not maintained either the grubbers had to wait occasionally for the team or some of the bushes pulled by the team were missed by the men following behind. The number of men necessary to maintain this ratio was found to vary from about 5 grubbers to each team in situations where the bushes were large and difficult to pull and where the digging was fairly easy to about 10 men to each team in places where the bushes pulled easily.

Still another factor determines what size of crew is most economical. In some areas of escaped barberries most of the bushes are very small and are scattered over an area of considerable size in which trees and other shrubs are growing. In areas of this kind the actual eradication of a bush may be less difficult than finding it. If one man attempts to cover such an area systematically, he usually will spend so much time keeping himself located that he will have relatively little time to find and eradicate the bushes, or else he will wander around destroying such barberries as he notices, but with the certainty that he will miss many.

Where several men are employed in such a situation they can be formed in a line with intervals varying from a few feet to several rods between men and in this formation work across the area. In such formation only the end men are required to attend to their locations in the area. All the others merely keep their places in the line. A crew of 5 or 6 men probably is as small as can operate satisfactorily in this manner, and one of 10 or 12 is more efficient. With large crews it is advantageous to have one man follow behind the line to check up on the work of the others and assist where necessary. In this formation, as has been said, only the end men in the line are responsible for the direction of the march. In crossing the area in one direction the man on one end will follow a predetermined line, while the other end man blazes a new line. 


\section{COST OF DIGGING BARBERRIES}

The cost of digging a barberry bush may vary within wide limits. In many cases small plants growing wild in sand or light loam may be pulled out by hand, and digging may not be necessary. The same is true of bushes 2 or 3 feet high which may have been recently planted. Even good-sized planted bushes often may be thoroughly removed in 15 minutes' work with a grub hoe. It is a common observation that planted bushes, as a rule, do not develop as large and extensive root systems as escaped bushes. This difference probably is due to the somewhat adverse soil conditions surrounding shrubbery in many plantings, as well as to the effects of transplanting. With the larger escaped bushes, and also some of the especially thrifty planted ones, thorough eradication may require an hour of hard work, and in some especially difficult cases, as where the roots of the bush are deep in rocky soil or intertwined with roots of larger trees, a half day or more may be needed. The following data illustrate what may be expected where large areas of escaped barberries are eradicated by digging.

In Rock County, in southern Wisconsin, about 2,000 escaped barberry bushes were found in a 10 -acre field. This field at one time had been used as a nursery, and when that was abandoned cedar trees were set out at about 30 -foot intervals. The trees had reached a good size when the barberries were found. Most of the bushes were growing under the trees and close around the trunks. Here the birds or cattle had dropped the seed and the young plants had found protection while establishing themselves.

At the time of the eradication, in August, 1920, the bushes varied from small plants, a foot or so high, to good-sized, well-established bushes. The weather was hot and the ground very dry, so that digging was difficult. The roots of the cedars also interfered with the work. Six men worked approximately five days, and a team of horses was employed for a full day. The total cost was $\$ 175.91$. The estimated number of bushes of all sizes eradicated was 2,000, which made the average cost of eradicating a bush 8.8 cents.

In 1921 a large number of sprouts developed in this field, and in 1922 four men were sent to the area to complete the eradication. They reported about 1,000 sprouting bushes (pl. 8). The actual cost of eradicating them was $\$ 209.50$, or a cost equal to 10.5 cents on each of the original 2,000 bushes. This was early in September, and again the ground was hard and digging difficult. This brought the total cost per bush up to 19.3 cents. An examination of the property in 1923 showed a large number of sprouts developing.

Another property, concerning which there are fairly accurate data, is in Dane County, Wis. Here the bushes varied from small to very large. About half of the bushes were in rocky soil. They were scattered over a 160-acre farm in the unglaciated section of the county. Digging was done in the latter part of August, 1921, at a total cost of $\$ 244.80$. About 2,000 bushes were dug at an average cost of 12.24 cents each. In 1922 a very large number of sprouts developed (pl. 9, A), and it was estimated that the cost of digging them would exceed the original cost of digging. By 1923, however, chemical methods of eradication were well developed, and the sprouts were treated with salt. 


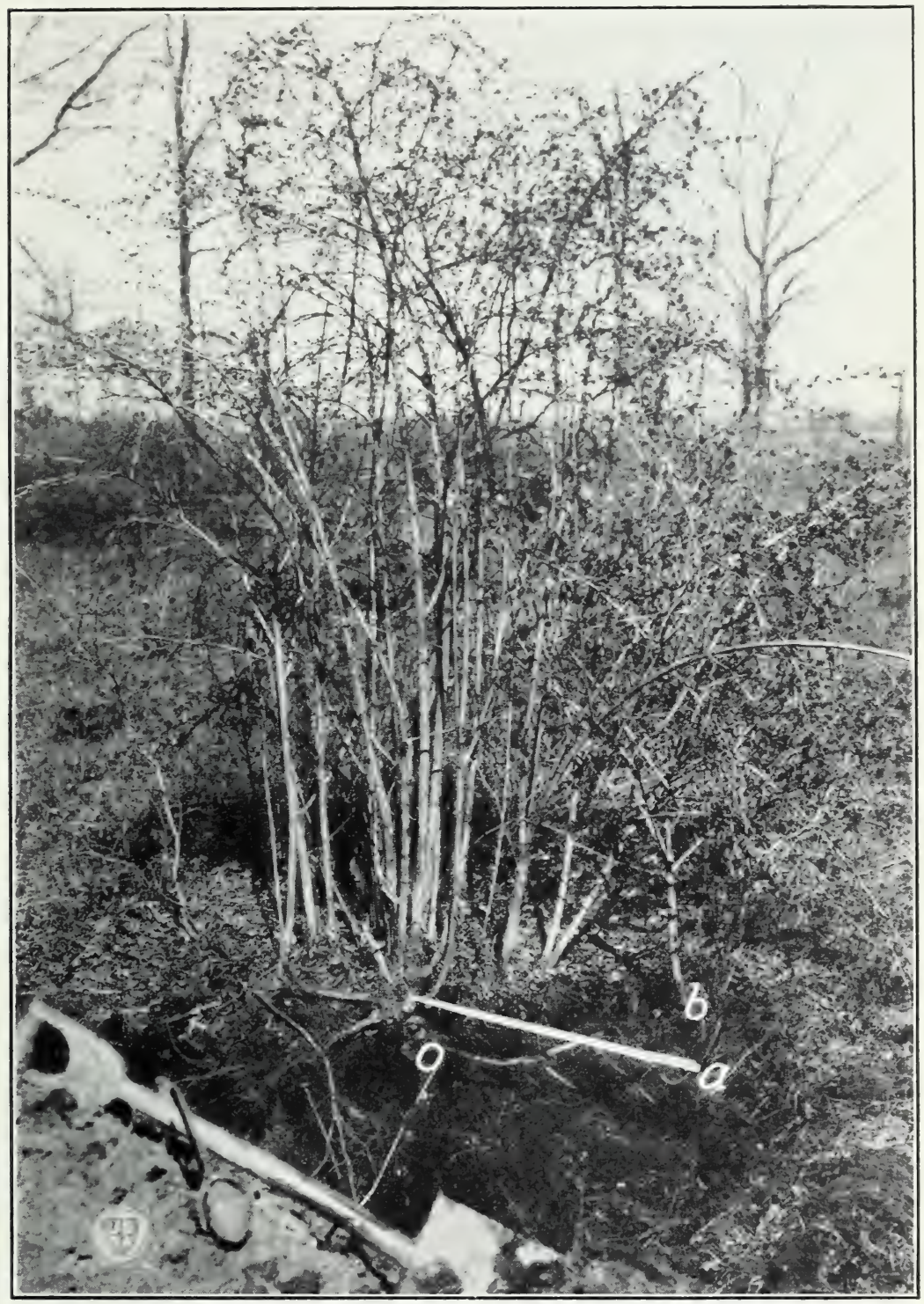

BARBERRY BUSH AND SHOOTS WITH RHIZOME EXPOSED

The shoot $a$ on the right (to which the tape is attached) and the shoot $b$ grew from the rhizome arising at 0 . (Compare with Plate $4, \mathrm{~B}$ ) 

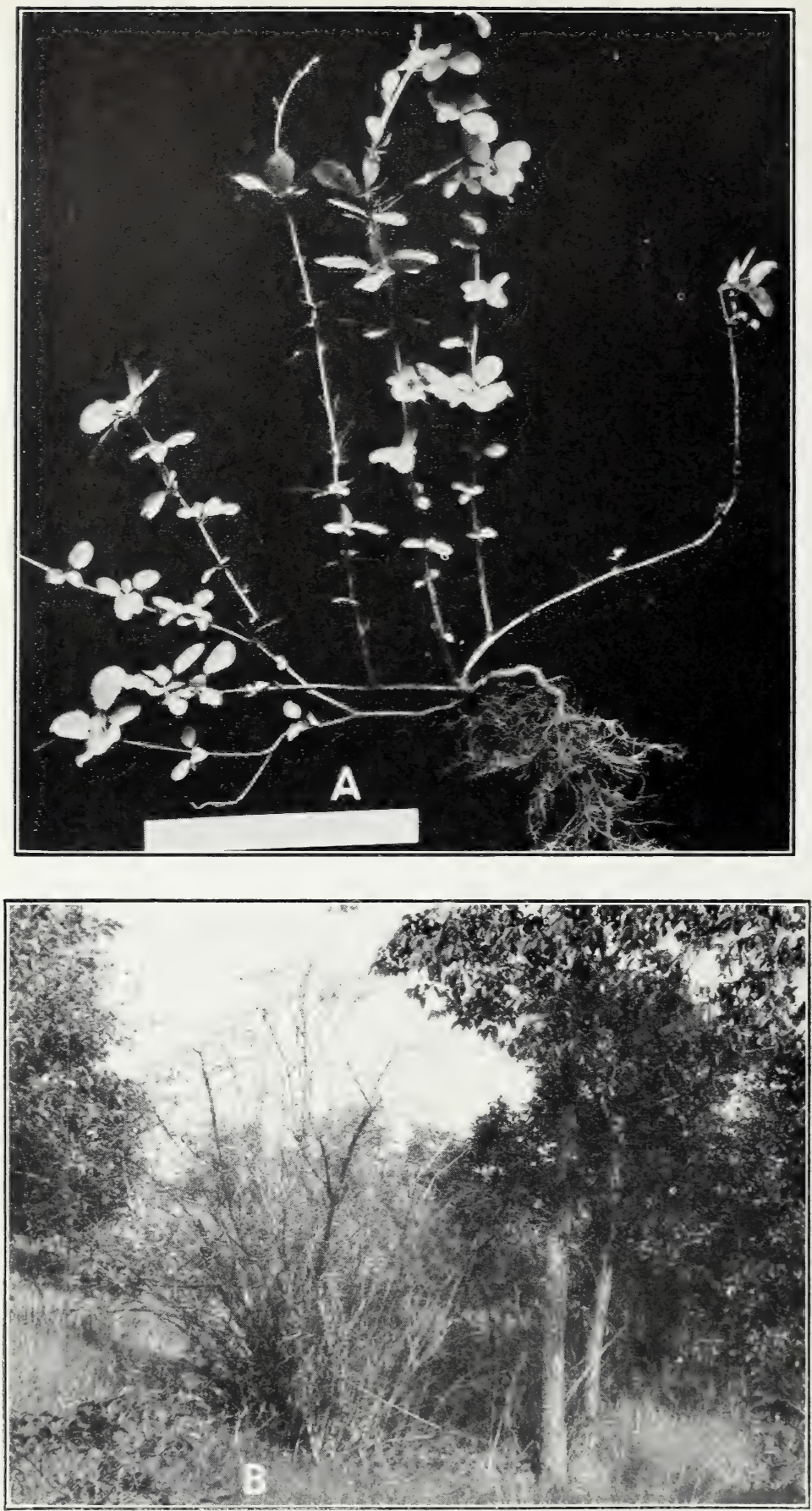

ROOT DEVELOPMENT AND LOCATION OF BARBERRY BUSHES, MAKING ERADICATION DIFFICULT

A.-A young barberry plant, probably 5 years old, typical of plants growing in the A. shade Note the slender shoots and the mass of fibrous roots

B.-Barberry bushes killed with sodium-arsenite solution on a property near Toledo, Ohio. Note that the trees near by were uninjurcd by the arsenic 

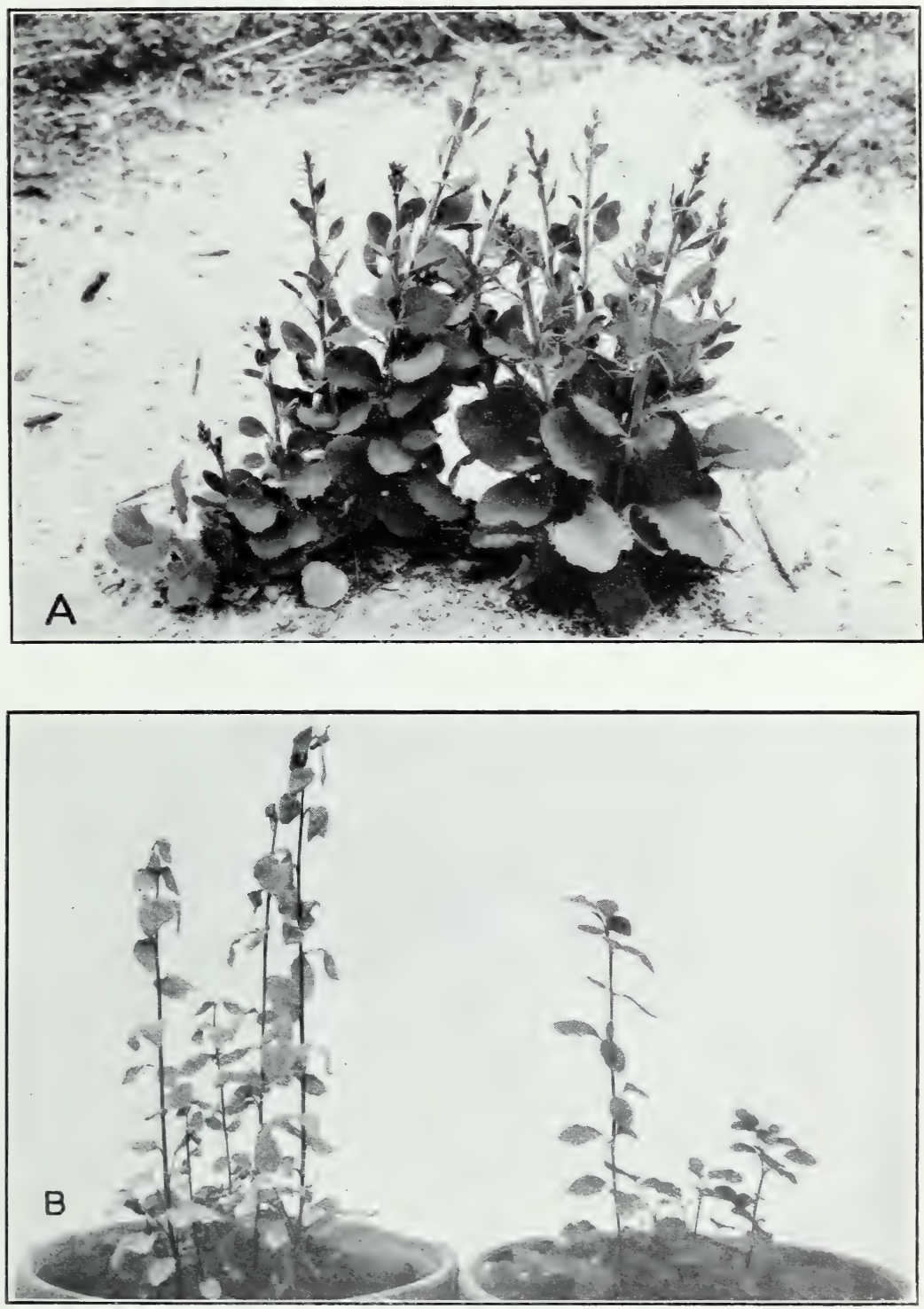

BARBERRY SPROUTS AND SMALL PLANTS

A.-Barberry sprouts found the year following removal of bushes. Complete eradication by digging is easier in sand than in any other type of soil, yet many sprouts have been found in such locations

B.-Type of small barberry plants, in 8-inch pots, used for preliminary tests of chemicals. The plant on the left was treated with 20 grams of calcium chloride 12 days before the photograph was taken. On the right is a control 

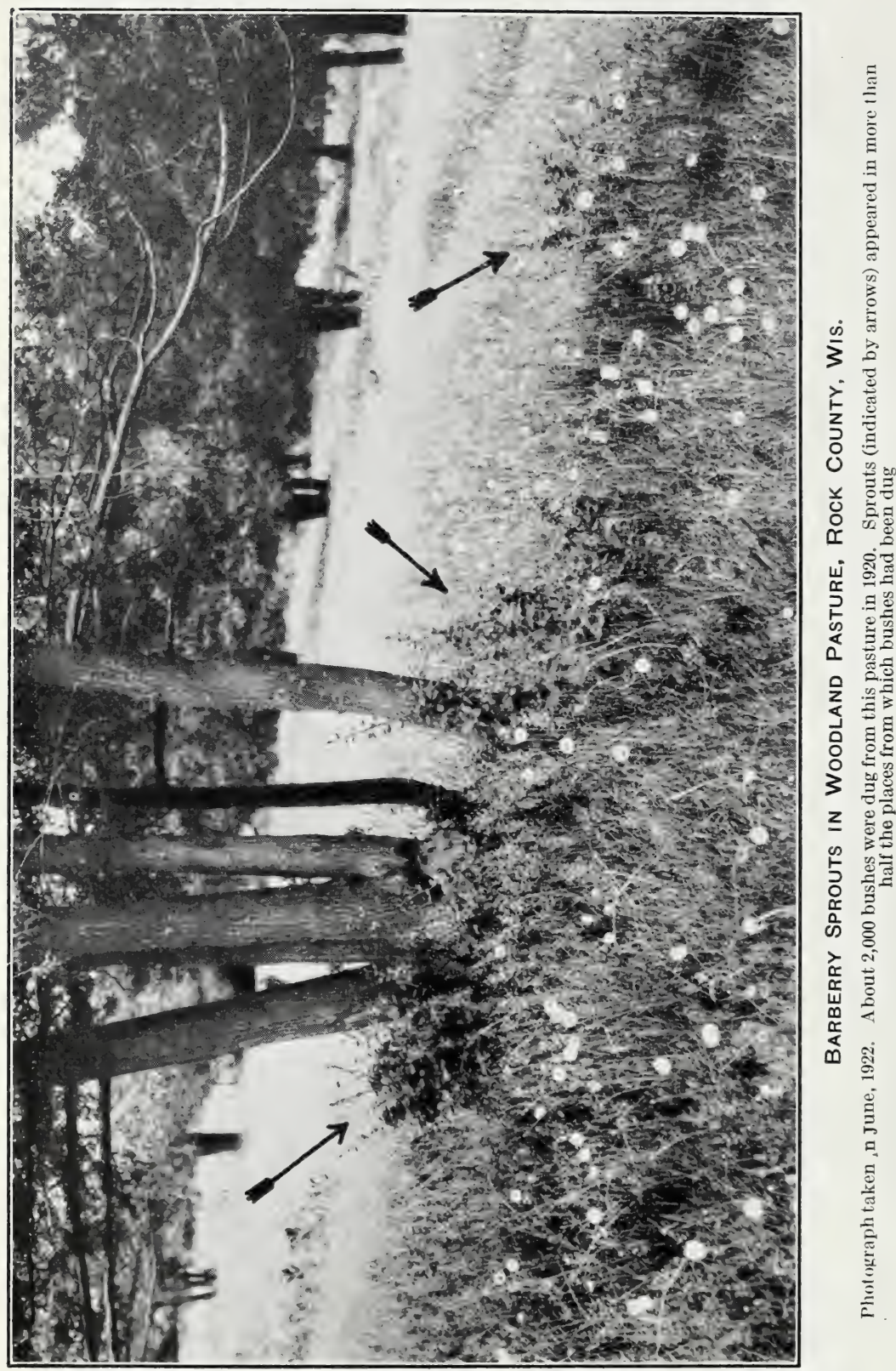

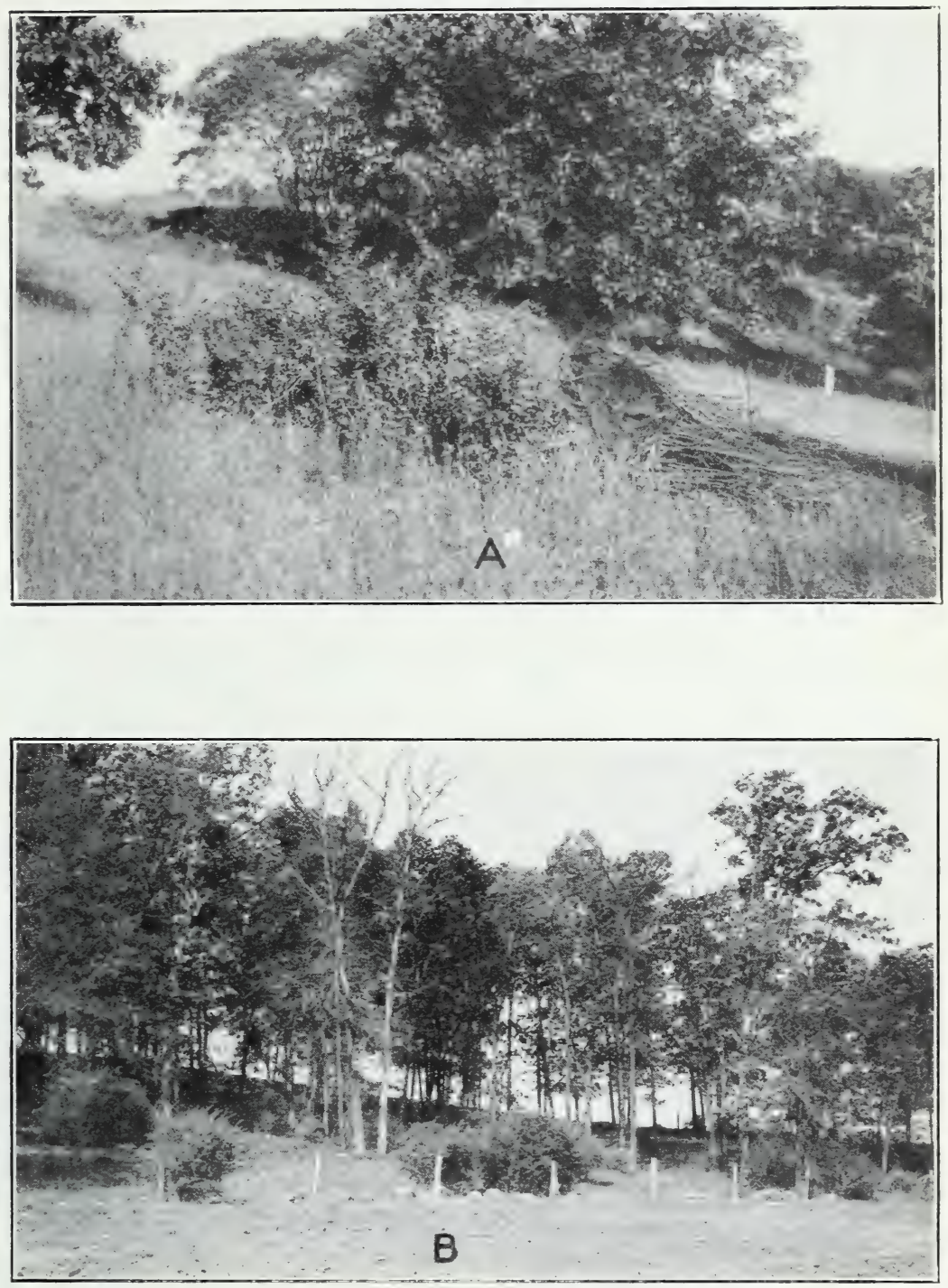

THOROUGHNESS:AND SKILL NECESSARY to Success OF ERADICATION METHODS

A.-Barberry sprouts growing from a hole from which the large bush at the right was remored (Dane County, Wis.). From portions of roots left in the ground a greater number of shoots arose than comprised the original bush

B.-Portion of wood lot near Mfarshall, Dane County, Wis. Some of the escaped barberries used for experimental treatments are here shown 

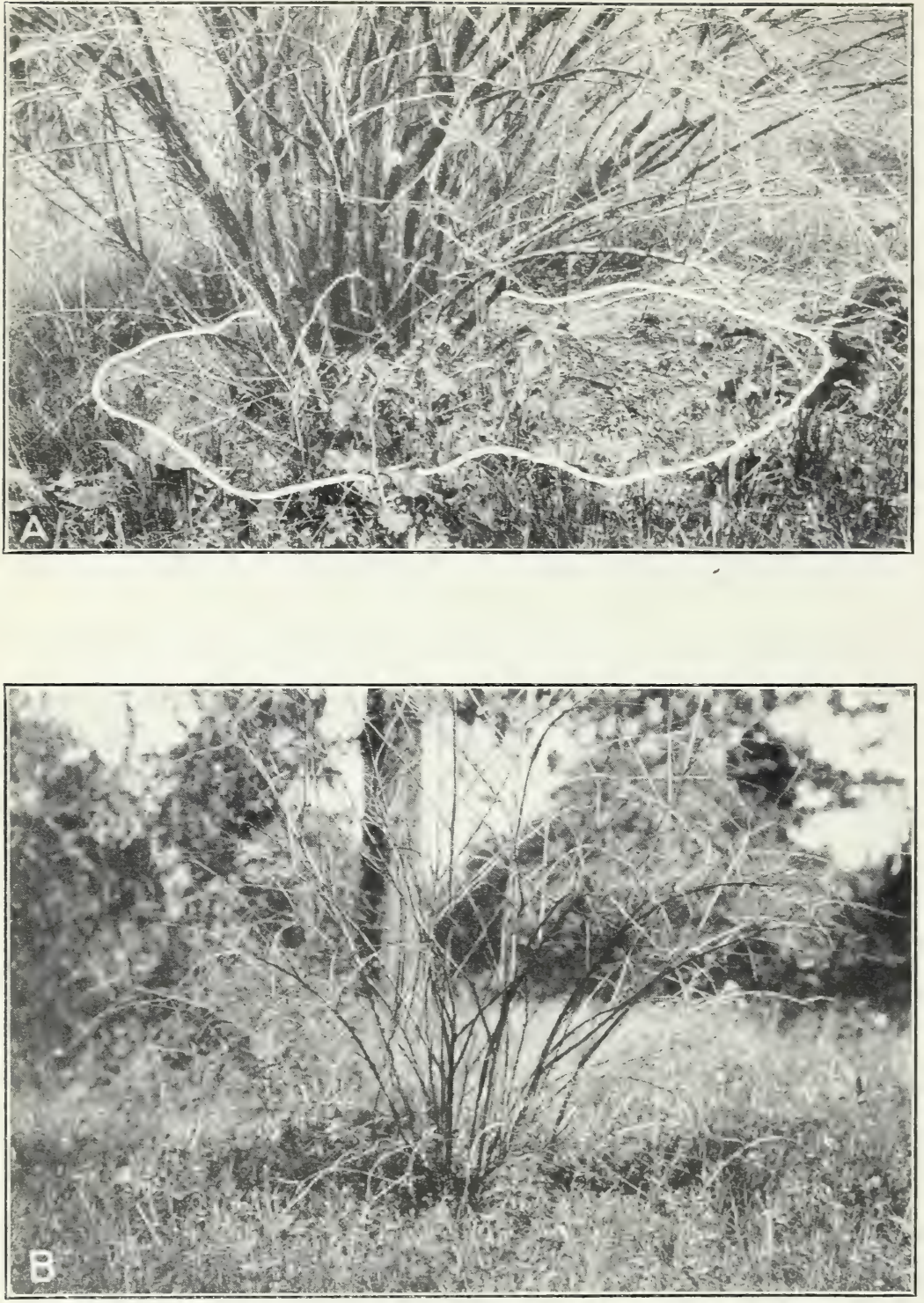

Use of Chemicals as Herbicides PRActiced for Many Years

A.-Base of a barberry bush killed with sodium-arsenite solution. The area of dead grass and

B. - A barberry bush killed with salt in a wood lot near Gurnee, Lake County, IIl. This bush is typical of those treated in this area 
These two cases are typical of all extensive areas of escaped barberries growing in heavy soil or rocky land, where the eradication by digging has been attempted in the 13 States engaged in the work. Very few such cases have come to the attention of the writers where complete eradication has even been approached by one digging. However, in light sandy loam in a thick woodland where the barberries have not reached a very large size or in very sandy situations one digging often has proved very successful. The tollowing is an illustration of such a case.

In Allegan County, Mich., a barberry hedge about 1,800 feet long was found growing in almost pure sand on an abandoned farm. This hedge was dug late in August, 1922. The bushes were cut into sections and teams were employed to pull them out. The roots were then dug by hand, after which the tops and roots were piled at one side and burned. The cost was as follows:

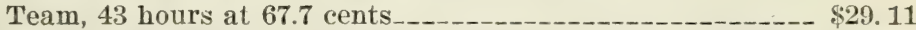

Labor, 294 hours at 43 cents_-_-_-_-_-_-_-_-_-_-_- 126.42

Incidental expenses, including subsistence and transporta-

tion of crew_._.

Total cost -

Estimating one barberry for each foot of hedge, there were 1,800 bushes, and the average eradication cost per bush was 15.4 cents. Less than a dozen sprouts appeared in 1923. A few of the bushes were not burned, and many of these took root and grew.

\section{DESTRUCTION OF SPROUTS}

Any attempt to kill a common barberry bush by occasionally cutting it down to the ground is futile. This procedure has been tried repeatedly with no apparent success. Cases have been observed where bushes that were growing in a lawn were cut down and thereafter the sprouts were kept cut with a lawn mower. They continued to develop for several years, gradually getting so tough that the lawn mower failed to cut them, and they again had to be cut out with an ax. If all sprouts were cut before they reached the surface of the ground, undoubtedly the roots could be starved out. Apparently this never has been attempted; consequently it is problematical how much time the operation would take.

Grazing often has been suggested as a means of destroying sprouts and killing the roots. Grazing by sheep or goats might do this effectively, but the writers have no knowledge of its ever having been successfully tried. Cattle will not destroy sprouts, although they occasionally browse on the tops. Hogs do not root up the sprouts and roots.

Many attempts have been made to kill the roots by cutting down the bushes and piling the tops, together with straw and brush, on the crown and burning them. In a few instances this has been successful, but more often it has failed. Even when such a procedure has been repeated two or three years in succession, sprouts have occurred, and digging or chemicals finally were required.

If it is possible to put barberry-infested land under cultivation, eradication is simple. This shrub will not grow long in a cultivated field, and a year or two of cultivation will see the last of the sprouts. 
But where this method is not practicable only two methods can safely be recommended. One is the actual digging of all the roots. 'This has been described already, and while it is expensive and may need to be repeated several times, it will lead ultimately to complete eradication. The other method is the use of a chemical.

\section{CHEMICAL METHODS OF ERADICATION}

A review of the literature shows that the use of chemicals as herbicides has been practiced for many years and that many different chemicals have been recommended at one time or another. Although a great deal of work has been done with certain chemicals and with their influence upon certain groups of plants, most of it has been of an empirical nature. Very little is known of the action of the chemicals upon the plant or the methods by which killing is effected.

Certain chemicals were reported to be very effective in killing certain plants when applied in a definite manner. Without knowing the laws governing the action of the chemical on the plant, one could only guess what the result of applying any certain chemical to a barberry might be. It was necessary actually to try a chemical to find out what it would do to the barberry. Moreover, it was necessary to apply it by different methods in varying quantities and at different seasons under different soil and climatic conditions.

One of the earlier reports of the use of a chemical in killing weeds is by Jones and Orton ( $(y)$ in Vermont in 1897. They found salt effective in killing the orange hawkreed and mention the fact that this chemical "has long been used in fighting weeds." In 1899 they (8) reported on the use of salt, copper sulphate, potassium sulphide, kerosene, sodium arsenite, and crude carbolic acid, and concluded that the last two were the most effective in keeping down weeds in tennis courts and along walks and drives.

About this same time Dusserre (4) in France reported experiments with copper sulphate, iron sulphate, and sodium nitrate in killing mustard in grain fields. Bolley $(\Omega)$ in North Dakota reported success in contrulling weeds in grain fields with a copper-sulphate spray.

In the next few years many papers reported the effectiveness of different chemicals in controlling weeds in grain fields. Ferrous sulphate and copper sulphate rere used most commonly, but sulphuric acid, phenol, sodium chloride, sodium nitrate and other fertilizers, sodium cyanide and cyanamide, and other chemicals were tried. All these materials were used as sprays or as clusts, and their effectiveness was due to killing the tops of the weeds.

Experiments on the eradication of other plants also were reported from time to time. In 1902 Potts (10) suggested pouring waste sulphuric acid from milk testing about the main roots of briers, blackberries, wild roses, etc. In the same year Valder (1\%) found that a solution of sodium arsenite was rery effective in killing the tops of prickly pear, but sprouts later developed from the roots. $\mathrm{He}$ also injected copper sulphate, sulphuric acid, carbolic acid, potassium oxalate, potassium ferro cyanide, sodium arsenite, caustic potash, iron sulphate, and common salt into the lower portions of the plants 
without much success. Rumbold $(12,13)$ injected various chemicals into chestnut trees in an attempt to kill the chestnut blight. Although the blight was not controlled by the treatments, the effects of the injections on the host were of great interest.

In reviewing the literature it is noticeable that most of the work has been done with substances used as sprays and with the intention of killing the tops of the plants. Very little has been done with poisons applied to the roots. Even with perennials that sprout readily from underground portions, attempts at killing usually are by means of sprays applied to the tops, as it is too costly to treat the soil sufficiently to kill all vegetation. The soil of walks, tennis courts, and similar areas has been treated to kill off a few annuals and prevent the establishment of other plants. A relatively small dose was sufficient. Rudolfs (11) recently has reported experiments in clearing land of brush and stumps by heavy applications of salt or sulphur, and a few other attempts of this nature have been made.

Mention should be made particularly of the recent work of Regan, ${ }^{2}$ of the Office of Blister-Rust Control, Bureau of Plant Industry, United States Department of Agriculture. In the attempt to find an efficient, economical method of killing Ribes plants he experimented with sereral chemicals. He made some tests with barberry plants also, using sodium-arsenite solution, dip oil, fuel oil, sodium-chloride solution, and dry sodium chloride. He found that when the chemical was applied to the base of the plant it was more effective than when applied as a spray to the aboveground portions. He states that "application of the chemicals to the cut-off stumps appears to be most effective in destroying the plants, but application to the base of the plants with the tops on gave practically as good results and inrolved much less labor."

\section{REQUIREMENTS FOR A SATISFACTORY CHEMICAL}

A chemical satisfactory for use in eradicating the common barberry must fulfill the following requirements, listed in the order of their importance:

Effectiveness.-The chemical must be effective in killing barberry bushes under varying soil and weather conditions and at most seasons of the year. It should be 100 per cent effectire under favorable conditions and should approach this even under adverse conditions.

Availability.-The chemical should be readily available; that is, it should be some substance which is in more or less common use, so that the supply will not be limited and the price subject only to the law of supply and demand.

Cost.-The cost of the chemical and of its application per bush should be less than the cost of equally effective digging.

Ease of handling.-The quantity needed for a single bush should not be excessive, nor should the method of application be difficult or require special tools.

Safety.-The substanee should be such that little or no danger will be experienced by those handling it or by persons or animals having access to treated bushes or to the chemical itself. It also

2 REgAN, W. S. FINAL REPORT ON TESTS WITH CHEMICALS FOR DESTROYING BARBERRY pLANTS. Unpublished manuscript. 
should cause a minimum of damage to harmless regetation and to the soil subjected to the treatment.

\section{EXTENT AND LOCATION OF EXPERIMENTS}

The experiments with chemicals reported in the following pages were begun in the fall of 1921 and continued up to the summer of 1925 , a period of more than three and one-half years. All laboratory and greenhouse tests were made at the University of Wisconsin, Madison, Wis. Many chemicals were tried in the greenhouse in winter on small potted barberries. (Pl. 7, B.) This was continued as an easy. quick method of testing in a preliminary way other chemicals that were added to the list from time to time. The potted plants were portions of roots or portions of shoots with some roots taken from large bushes in the field. Most of these cuttings grew readily and produced an abundance of small roots as well as thrifty shoots. They were potted for the most part in 8-inch flower pots in rich loam and were used when the shoots were 12 inches or more in height. Several plants commonly were used for each test, and controls always were kept.

It was calculated that 5 grams of a chemical applied to a barberry plant growing in an 8-inch pot was equivalent to 1 pound applied to a bush not over 12 inches in diameter at the base growing in the field. Approximately 40 cubic centimeters of a solution applied to a barberry growing in an 8-inch pot was considered equiralent to an application of 1 gallon in the field. It is evident that these estimates of the quantity of any chemical applied in the field which would be equivalent to a certain application to a potted barberry are only approximate. The results showed that the action of a chemical applied to a barberry in the field can not be predicted with certainty from tests with the same chemical in the greenhouse. Nevertheless, the method is a convenient one and serves as an indicator of what may be expected in the field.

The field operations were of two kinds: (1) Treating with a series of chemicals a series of individual, marked barberry bushes growing naturally in the field and of as nearly the same size as possible; (2) treating with one chemical all the barberries growing in a certain area.

The individual bushes used for testing the chemicals were in Dane County, Wis., and Lake County, Ill. In Dane County escaped bushes growing on several farms a few miles south of Black Earth were used. This area was rather hilly. Limestone underlaid the soil, and there were frequent outcroppings of this rock on the hillsides. In another location in Dane County barberries were treated on a farm about 1 mile north of Marshall. Here a barberry hedge surrounded a small orchard. These bushes were treated, as trere also many escaped bushes in a near-by pasture.

(Pl. 9, B.)

When no more suitable bushes were available in these two areas bushes were selected on two farms about 2 miles northwest of Gurnee, Lake County, Ill. This area, in which barberries of unknown origin were growing wild on about 50 acres of wooded pasture land, is nearly level and has a rich loam over gravel.

More than 2,600 separate marked bushes of approximately uniform size and character were treated in these three areas. The 
height of a bush can not be taken alone as an indication of its vigor, as this is dependent to a great extent on the amount of light it receives, as well as on soil conditions. Barberries growing in the shade of trees usually are taller though less vigorous than bushes growing in direct sunlight. Browsing or cutting back also may affect the height of a bush. Likewise, the diameter of individual stalks is not a character that can be used, as the stalks seldom attain a diameter of over 2 inches, and new stalks are being produced continually around the periphery of the clump.

The diameter of the clump or bush at the surface of the ground was therefore taken as an index, and a bush with a diameter of 12 inches at the base was arbitrarily selected as an average-sized one. All treatments were made on this basis, and the results are those which may be expected when bushes of this size are treated. For larger or smaller bushes more or less of the chemical would be required to give the same results.

A few chemicals that appeared especially satisfactory from the field tests on marked bushes were tried out on a larger scale. For this purpose fields were selected where numerous barberries were growing wild. Only one chemical was used in a field, and all bushes were treated in the same manner. The quantity applied to an individual bush was determined by the size of the bush, using as a basis the most satisfactory treatment for an average bush as determined by previous tests. In this way there was obtained not only an idea as to the action of the chemical on bushes of various sizes but also an indication of the cost of treating areas of escaped barberries. These tests were made in various localities in Wisconsin, Iowa, Illinois, Michigan, and Ohio.

\section{CHEMICALS USED}

Thirty-seven different chemical substances that were tested are reported in this bulletin. Others were tried either in the greenhouse or in the field or both, but the results are not reported. Trials with some have not yet been completed. Some mixtures obtained from different firms were tested, but the results are not given because the composition is not known to the writers. None of these latter preparations, however, were so satisfactory, from the standpoint of either effectiveness or cost, as the best reported in this bulletin.

The following is a list of the chemical substances in the order in which they will be discussed in this bulletin:

Inorganic salts.-Borax and boric acid, calcium chloride, ferrous sulphate, mercuric chloride, sodium arsenite, sodium chloride, sodium dichromate.

Acids and acid formers.-Kerosene acid sludge (15 per cent sulphuric acid), phenol, picric acid, sulphur (inoculated).

Gas-forming substances.-Calcium carbide, calcium cyanide, carbon bisulphide, paradichlorobenzene, sodium cyanide.

Oils and other organic substances.-Ammonium picrate, benzene, creosote oil (light), metacresol, orthodichlorobenzene and metadichlorobenzene, petroleum fuel oil, furfural (furfaraldehyde), petroleum gas oil, gasoline, kerosene, monochlorobenzene, nitrobenzene, paranitrochlorobenzene, orthonitrotoluene, paratoluenemonosulphonic acid, paratoluenesodiumsulphonate, paratoluenesulphochloride, orthotoluidine, paratoluidine, water-gas drip-oil, and water-gas tar. 


\section{BORAX AND BORIC ACID}

The harmful effects of extremely small quantities of borax $\left(\mathrm{Na}_{2} \mathrm{~B}_{4} \mathrm{O} 7.10 \mathrm{H}_{2} \mathrm{O}\right)$ in fertilizers have been reported by Brown (3) and other investigators. In the fall of 1924 this chemical was tried in the greenhouse on barberries growing in 8-inch pots. To the surface of the soil in one pot was applied 5 grams and to another pot 1 gram of commercial package borax. To the soil in a third pot 50 cubic centimeters of a saturated solution of boric acid $\left(\mathrm{H}_{3} \mathrm{BO}_{3}\right)$ was applied. This solution contained approximately 2 grams of the chemical.

The effects of the chemical were slow in appearing, but within two weeks all the leaves of the plants receiving 5 grams of borax were dead. The plants in the other two pots had many dead leaves, but some leaves were still green. Two months after the treatment plants in all the pots were putting out new leaves, and three months after the treatment they were still growing. These results were not sufficiently satisfactory to warrant field treatments with borax and boric acid.

\section{CALCIUM CHLORIDE}

Calcium chloride has been used to some extent as a herbicide, and its similarity to sodium chloride in chemical composition suggested that it might be a valuable chemical for the purpose in hand. It is available in quantity, and its use as a road dressing to keep down dust and to hold the soil moisture makes it readily available in many sections of the country. A quantity of crushed, sacked calcium chloride therefore was obtained and treatments were made, paralleling in general those with sodium chloride.

In the greenhouse it was found that 20 grams, or about the estimated equivalent of 4 pounds in the field, was sufficient to kill small barberries in 8-inch pots in 12 days. The cost of the chemical was about 1.5 cents a pound, so that it seemed worth while to continue the experiments in the field.

TABLE 1.-Summary of treatments of individual, marked barberry bushes with calcium chloride

\begin{tabular}{|c|c|c|c|c|c|c|c|c|}
\hline $\begin{array}{l}\text { Date of } \\
\text { treat- } \\
\text { ment }\end{array}$ & $\begin{array}{l}\text { Date of } \\
\text { final ob- } \\
\text { serva- } \\
\text { tion }\end{array}$ & $\begin{array}{l}\text { Quan- } \\
\text { tity of } \\
\text { chemi- } \\
\text { cal to } \\
\text { the bush } \\
\text { (pounds) }\end{array}$ & Method of application & $\begin{array}{l}\text { Bushes } \\
\text { cut of or } \\
\text { left stand- } \\
\text { ing }\end{array}$ & $\begin{array}{c}\text { Location of } \\
\text { area }\end{array}$ & $\begin{array}{l}\text { Bushes } \\
\text { treated }\end{array}$ & $\begin{array}{l}\text { Bushes } \\
\text { killed }\end{array}$ & $\begin{array}{c}\text { Per- } \\
\text { centage } \\
\text { killed }\end{array}$ \\
\hline 1922 & 1923 & & & & & & & \\
\hline $\begin{array}{l}\text { Apr. } 27 \\
\text { Do.... }\end{array}$ & $\begin{array}{l}\text { July } 3 \\
\text { do }\end{array}$ & $\begin{array}{l}5 \\
5\end{array}$ & $\begin{array}{l}\text { Circle of } 1 \text {-foot radius.- } \\
\text { - }\end{array}$ & $\begin{array}{l}\text { Cut off....- } \\
\text { Standing.- }\end{array}$ & $\begin{array}{l}\text { Gurnee, III } .- \\
\text {...... do }\end{array}$ & $\begin{array}{l}20 \\
20\end{array}$ & $\begin{array}{l}7 \\
9\end{array}$ & $\begin{array}{l}35 \\
45\end{array}$ \\
\hline Do... & do........... & 10 & doc- & Cut off...- & do................ & 20 & 16 & 80 \\
\hline Do.... & ...do_..... & 10 & ................. & Standing.- & .............. & 20 & 16 & 80 \\
\hline Do.... & ... do...... & 15 & .... do................ & Cut off.... & .... do & 20 & 14 & 70 \\
\hline Do & ... do do..... & 15 & - do do............... & Standing.- & ..... do do........ & 20 & 15 & 75 \\
\hline July 10 & ....do...... & 15 & Piled in base........... & Cut off-... & ..... do do..... & 20 & 20 & 100 \\
\hline Do.... & .... do_..... & 15 & 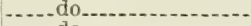 & Standing.- & . & 20 & 20 & 100 \\
\hline Oct. 16 & ....do...... & 15 & ..... do do & Cut off..... & ................. & 20 & 20 & 100 \\
\hline & & & & & & & & \\
\hline & & & & & & 200 & 156 & 78 \\
\hline
\end{tabular}


As shown in Table 1, the first six treatments were made by piling the salt in a ring around the base of the plants. No clinerence could be observed in the effectiveness of this method on the bushes cut down and on those left standing. On comparison with treatments made with sodium chloride on the same day and in the same manner the following clifferences were noted: Of the 40 bushes receiving 5 pounds each of calcium chloride, only 40 per cent were killed, whereas the corresponding sodium-chloride treatment killed 75 per cent of the bushes. With 10 pounds of the chemical to the bush, calcium chloride killed 80 per cent and sodium chloride $971 / 2$ per cent; and with 15 pounds, $721 / 2$ and $971 / 2$ per cent, respectively, wcie killed.

Before the treatment made on July 10, 1922, it had become evident that the treatments were more effective when the chemicals were piled in the base of the plant than when placed in a circle around the base. This method was followed in the remaining treatments, and on account of the poor showing made by calcium chloride in the earlier treatments, a 15-pound application was made. As shown by the table, this failed to kill all of the 80 bushes treated.

Calcium chloride is very hygroscopic. When shipped it is usually packed in tins or in paper-lined sacks to exclude moisture. When the containers are opened moisture is absorbed rapidly by the chemical, and it becomes wet and sticky. In handling, much of the chemical adheres to the clothes and hands and makes the operation very disagreeable. Although this in itself should not condemn a chemical that otherwise may be satisfactory, it should be taken into consideration.

It may be that this hygroscopic character of calcium chloride is accourtable for the poor showing it made in comparison with sodium chloride. It was noticed that when the latter was piled around a barberry bush in the quantities used in this work it usually was several months before it all dissolved, whereas calcium chloride usually dissolved completely in a few days. The action of calcium chloride on vegetation other than the barberry was very similar to that of sodium chloride. Grass and weeds near the treated spot were killed and occasional shrubs were injured. Its sterilizing action on the soil did not continue for so long a period, however.

\section{FERROUS SULPHATE}

Ferrous sulphate $\left(\mathrm{FeSO}_{4} \cdot \tau \mathrm{H}_{2} \mathrm{O}\right)$ has been used for many years as a herbicide, especially for killing young weeds in grain fields and in grass plots. Although it was known to be a mild herbicide, there was a possibility that it might be specific for barberries. It was therefore tried out in the greenhouse. Doses as large as 10 grams dissolved in 1.00 cubic centimeters of water failed to kill small barberries growing in 8-inch pots. On account of this. unsatisfactory showing of ferrous sulphate as compared with some of the other chemicals field tests were not made.

\section{MERCURIC CHIORIDE}

Mercuric chloride $\left(\mathrm{HgCl}_{2}\right)$ also was tried out in the greenhouse, but with unsatisfactory results; consequently no field tests were made. With small barberries in 8 -inch pots, 6 grams of mercuric chloride in 200 cubic centimeters of water failed to produce death. 


\section{SODIUM ARSENITE}

Sodium arsenite is generally considered one of the most effective of the common herbicides. The use of the various forms of arsenic as insecticides also has resulted in an extensive literature dealing with the results produced on plants by various applications of these substances. The insoluble forms are very slightly, if at all, toxic to plants, but the soluble forms are all toxic, and of these sodium arsenite is one of the most toxic. Schulz and Thompson (1/4) performed experiments to determine roughly the most toxic form of arsenic. This proved to be arsenious acid, $\mathrm{H}_{3} \mathrm{AsO}_{3}$. This acid is produced by dissolving white arsenic, $\mathrm{As}_{2} \mathrm{O}_{3}$, in water, but since it is only slightly soluble it is not a satisfactory herbicide for this purpose, and sodium arsenite was selected for study. Sodium arsenite may be in various forms containing more or less sodium to the molecule. Some of the possible forms are $\mathrm{NaAsO}_{2}, \mathrm{Na}_{3} \mathrm{AsO}_{3}$, $\mathrm{Na}_{2} \mathrm{HAsO}_{3}$, and $\mathrm{NaH}_{2} \mathrm{AsO}_{3}$. In solution these probably all dissociate to form arsenious acid and sodium hydroxide. The less sodium there is in the molecule the more arsenious acid may be formed and the more toxic is the solution. For field use, however, the action of the soil solutes on the arsenic must also be considered. In some cases it may be an advantage to have a strongly alkaline solut:on.

The commercial sodium arsenite selected and used in most of the experiments was a product known as "8-pound" material. It is formed from 8 pounds of white arsenic and about 2 pounds of sodium hydroxide with water sufficient to make a gallon. Each gallon weighed about 16 pounds.

In greenhouse tests 4 cubic centimeters of this material in 80 cubic centimeters of water killed barberries in 8-inch pots in eight days. This was so satisfactory that field tests were made. Some of the field tests with "8-pound" sodium-arsenite solution are summar:zed in Table 2.

At the time these tests were begun the writers had only a general idea of the root system of the barberry. As there were long. loots radiating from the crown, it was thought that by placing the chemical in a ring around the barberry, but at a little distance from it, the lateral roots and the entire bush might be killed. In most of the treatments recorded in Table 2, the sodium-arsenite solution was placed in a ring around the bush. An examination of this table will show that where the solution was applied in a circle with a 2 foot radius only 30 per cent of the total number of bushes treated were killed. Where the radius of the circle was only 1 foot about 4.5 per cent of the treated plants were killed, and where the solution was applied to the base of the plant as a drench about 98.5 per cent were killed. This indicated that the barberry was most susceptible to chemicals immediately around the base of the shoots. Later studies of the root system indicated the reason for this, as has already been explained.

The results reported in Table 2 indicate another point. Sodium arsenite was known to be an extremely active plant poison. It was suspected that a small quantity would kill a bush if it could reach the living tissues. It remained to be determined how killing could be done most economically. If a small quantity of the substance. 
applied in a concentrated form would kill a bush, the field transportation costs would be low. Therefore, the chemical was applied in various dilutions.

TABLE 2.-Summary of treatments of individual, marked barberry bushes with sodium arsenite

\begin{tabular}{|c|c|c|c|c|c|c|c|c|c|}
\hline $\begin{array}{l}\text { Date of } \\
\text { treat- } \\
\text { ment }\end{array}$ & $\begin{array}{l}\text { Date of } \\
\text { final ob- } \\
\text { servation }\end{array}$ & $\begin{array}{l}\text { Quan- } \\
\text { tity of } \\
\text { basic } \\
\text { sole- } \\
\text { tion } 1 \\
\text { to the } \\
\text { bush }\end{array}$ & $\begin{array}{l}\text { Dilu- } \\
\text { tion, ba- } \\
\text { sic solu- } \\
\text { tion to } \\
\text { water }\end{array}$ & $\begin{array}{l}\text { Method of appli- } \\
\text { cation }\end{array}$ & $\begin{array}{l}\text { Bushes cut } \\
\text { off or left } \\
\text { standing }\end{array}$ & $\begin{array}{l}\text { Location } \\
\text { of area }\end{array}$ & $\begin{array}{l}\text { Bushes } \\
\text { treated }\end{array}$ & $\begin{array}{l}\text { Bushes } \\
\text { killed }\end{array}$ & $\begin{array}{l}\text { Per- } \\
\text { centage } \\
\text { killed }\end{array}$ \\
\hline $\begin{array}{c}1922 \\
\text { A pr. } 20\end{array}$ & $\begin{array}{c}1923 \\
\text { June } 27\end{array}$ & $\begin{array}{l}\text { Pint } \\
0.2\end{array}$ & None. & $\begin{array}{l}\text { In circle of } 1 \text { - } \\
\text { foot radius. }\end{array}$ & Standing.- & $\begin{array}{l}\text { Marshall, } \\
\text { Wis. }\end{array}$ & 5 & 4 & 80 \\
\hline $\begin{array}{l}\text { Do... } \\
\text { Do... } \\
\text { Do... } \\
\text { Do... } \\
\text { Do... } \\
\text { Do... } \\
\text { Do ... }\end{array}$ & 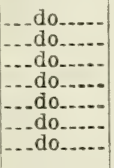 & $\begin{array}{l}.3 \\
.3 \\
.3 \\
.2 \\
.2 \\
.2 \\
.3\end{array}$ & $\begin{array}{l}1 \text { to } 1 \\
1 \text { to } 2 \\
1 \text { to } 4 \\
1 \text { to } 8 \\
1 \text { to } 12 \\
1 \text { to } 16 \\
\text { None. }\end{array}$ & $\begin{array}{c}\text { do dourus } \\
\text { In circle of } 2- \\
\text { do do } \\
\text { do do }\end{array}$ & $\begin{array}{c}\text { [....d do } \\
\ldots \text { do }\end{array}$ & 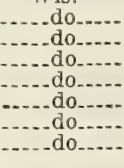 & $\begin{array}{l}5 \\
5 \\
5 \\
5 \\
5 \\
5 \\
5\end{array}$ & $\begin{array}{l}0 \\
2 \\
3 \\
3 \\
3 \\
1 \\
1\end{array}$ & $\begin{array}{r}0 \\
40 \\
60 \\
60 \\
60 \\
20 \\
20\end{array}$ \\
\hline $\begin{array}{r}\text { Do... } \\
\text { Do... } \\
\text { Do... } \\
\text { Do... } \\
\text { Do... } \\
\text { Do... } \\
\text { Do... } \\
\text { May } 20\end{array}$ & 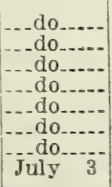 & $\begin{array}{l}.3 \\
.3 \\
.3 \\
.2 \\
.2 \\
.2 \\
.2 \\
.4\end{array}$ & $\begin{array}{l}1 \text { to } 1 \\
1 \text { to } 2 \\
1 \text { to } 4 \\
1 \text { to } 8 \\
1 \text { to } 12 \\
1 \text { to } 16 \\
1 \text { to } 20 \\
1 \text { to } 10\end{array}$ & $\begin{array}{c}\text { foot radius. } \\
\\
\text { do do }\end{array}$ & \begin{tabular}{|c|}
$\ldots$ do do \\
$\ldots$ do
\end{tabular} & 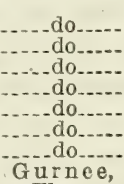 & $\begin{array}{r}5 \\
5 \\
5 \\
5 \\
5 \\
5 \\
5 \\
15\end{array}$ & $\begin{array}{r}0 \\
0 \\
5 \\
2 \\
2 \\
1 \\
1 \\
14\end{array}$ & $\begin{array}{r}0 \\
0 \\
100 \\
40 \\
40 \\
20 \\
20 \\
93\end{array}$ \\
\hline $\begin{array}{l}\text { Apr. } 28 \\
\text { Do } \\
\text { Apr. } 18\end{array}$ & ..don..... & $\begin{array}{l}.4 \\
.4 \\
.4\end{array}$ & $\begin{array}{l}1 \text { to } 20 \\
1 \text { to } 20 \\
1 \text { to } 40\end{array}$ & - do do & $\begin{array}{l}\text { Cut off...... } \\
\text { Standing.-. }\end{array}$ & Marshall, & $\begin{array}{l}20 \\
20 \\
20\end{array}$ & $\begin{array}{l}20 \\
20 \\
20\end{array}$ & $\begin{array}{l}100 \\
100 \\
100\end{array}$ \\
\hline & & & & & & & 150 & 102 & 68 \\
\hline
\end{tabular}

1 A commercial product known as an "8-pound" sodium-arsenite solution was used.

When applied in a circle around the bush it appeared that dilutions of from 1 to 4 to 1 to 12 were the most effective. However, this method was not so effective when applied as a drench, and a 1 to 20 solution was more effective than a 1 to 10 solution in the latter method. The results indicated that the chemical must be applied to the soil immediately around all shoots and that sufficient solution must be used to insure that all roots in that location would be reached. They also indicated that while a concentrated solution killed portions of the plant, it was not absorbed in sufficient quantity to kill all parts of a plant. Therefore, it was concluded that a dilute solution was more effective than a concentrated one. Taking all this into consideration, a drench consisting of 0.4 pint of "8-pound" sodium-arsenite solution in 2 gallons of water was decided upon for further experimentation.

\section{AREA TREATMENTS}

Near Holland, Ohio, about 10 miles west of Toledo, is a large stone quarry. The company operating this owns considerable land adjacent to the present quarry. Most of this land is not cultivated and has grown up to brush and small trees, including many escaped barberry bushes. The soil varies from a sandy loam to gravel underlain at a depth of a few inches to several feet by sandstone. Two soil analyses showed the surface soil to be slightly alkaline $\left(\mathrm{P}_{\mathrm{Y}} 7.5\right)$. 
On August 16 and 17, 1922, 364 mid-sized to very large barberry bushes in this area were treated with a dilute sodium-arsenite solution. The solution was made by mixing 1 gallon of "8-pound" sodium arsenite in a barrel with about 40 gallons of water. The water was hauled to the field in barrels on a light truck and the mixing was done as near the barberries as practicable. The solution was then carried to the bushes in 10-quart pails and poured among the shoots and around the bases of the plants. An effort was made to wet the base of every shoot and also the ground for a distance of about a foot around each shoot. At the time the treatment was made the weather was hot and the ground was very dry, so that the solution was absorbed rapidly. The cost items are as follows:

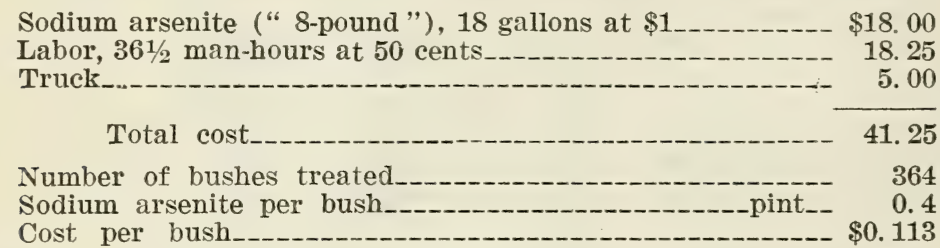

This property was inspected September 26, 1922. The leaves of nearly all the treated bushes were brown and falling, though there were a few green leaves remaining on some. The inner bark and outer layers of wood on the treated bushes were brown instead of the normal yellow color, and there was a slight odor as of decayed wood around the bushes. The grass around the treated bushes was dead to a distance of 2 or 3 feet $(\mathrm{pl} .10, \mathrm{~A})$. It was evident that some bushes had been missed when the treatment was made. That they had not received any arsenic was shown not only by their healthy condition but by the grass and weeds growing near them.

The property was inspected again in the summer of 1923 . By this time nearly all of the treated bushes were dead (pl. 6, B). Two or three had a few green shoots and would survive.

This experiment appears to have been nearly 100 per cent effective, so far as bushes actually treated are concerned. It emphasizes the necessity of taking special precautions in order to avoid missing bushes in an area of escapes, and also of the possible addition to the sodium-arsenite solution of a dye, such, for instance, as phenolphthalein, to color the solution and indicate where it has been placed.

On September 25, 1922, 1 gallon of "8-pound" sodium arsenite was used to treat 12 escaped barberry bushes growing on a property about 12 miles west of Pontiac, Mich. There were about 100 escaped bushes on this property, most of them growing along th's banks of the Huron River in very sandy soil. All but 12 of the bushes were dug, the larger ones being first dynamited. The cost of the dynamite, fuse, and cap totaled about 16 cents a bush. Because of the sandy nature of the soil, digging was fairly easy, and only a few sprouts were found the following year. Of the 12 bushes that were treated with sodium arsenite, 3 were large and the rest of medium size. The arsenic solution was mixed 1 to 40, and about 2 gallons of it was applied to the mid-sized bushes and as much as 7 gallons to the largest. One of the large bushes which received 4 gallons was on the edge of the bank about 3 feet above the water in 
the river. It was possible to pour the solution only in the upper side of this bush, and the ground was first scored slightly to keep it from running off too rapidly.

On September 28, only three days after the application of the sodium arsenite. the State leader of barberry eradication in Michigan wrote that the "large bushes looked sick and the smaller ones looked sicker." In the summer of 1923 they were inspected again, and no signs of life were detected in any of them.

On a farm about 12 miles northwest of Richland Center, Richland County, Wis., about 118 escaped barberry bushes were treated with sodium-arsenite solution on October 14, 1922. Most of these bushes were growing in an open pasture and some of them were unusually large. The soil was a shallow loam over limestone. The roots of most of the bushes penetrated crevices in the limestone, so that digging would have been extremely difficult. Water for the treatment was hauled into the field in a tank wagon, and the solution was mixed at the rate of about 1 gallon of " 8 -pound" material to 50 gallons of water. For mid-sized bushes only 2 gallons of this solution was used, although the largest ones received as much at 14 gallons. It had been raining previous to the date of treatment and the ground was very wet. After the treatment the weather remained cool. The cost was as follows:

Sodium arsenite ("8-pound"), 10 gallons at $\$ 1.25 \ldots \ldots \ldots$

Labor, 21 man-hours at 50 cents

Team and wagon, $5 \frac{1}{4}$ hours at 50 cents_____._._._._. 2.63

Total cost _. 25.63

Number of bushes treated_______- 118

Sodium arsenite per bush_____ 0.68

Cost per bush

Examination of this area in 1923 and again in 1924 showed that most of the mid-sized bushes had been killed but that nearly all of the large bushes as well as some of the mid-sized ones were only partially killed. Some shoots on every bush treated were killed, but occasional shoots survived. So far as known this is the only failure of sodium-arsenite solution, applied as here stated, to kill barberries, and large quantities of this chemical have been used since for this purpose. The explanation is that the arsenic was not absorbed by the plants in sufficient quantity. Whether this was due to the formation of insoluble calcium, iron, or other compounds of arsenic before the plant could absorb it, or to the wetness of the soil at the time of treatment, or to the lateness of the season, is debatable. It appears probable that all three factors were responsible. Because of the lateness of the season, transpiration and therefore absorption of moisture by the plant were very limited. The moisture already in the soil prevented the arsenic solution from rapidly reaching the roots of the plants, and before growth started the following spring much of the sodium arsenite had been rendered insoluble.

\section{SODIUM CHLORIDE}

Common salt (sodium chloride, $\mathrm{NaCl}$ ) has long been used as a herbicide. The salt used in these experiments was a coarse, crushed rock salt and also a finely ground rock salt. Crushed rock salt comes 
in various sizes. That used in the experiments was the size of a pea and smaller. No notable difference was observed in the effectiveness of the different grades of crushed salt, nor was any pronounced difference observed in the rate of solution of the various grades. When piled around a bush and moistened by rain, the salt cakes and does not become completely dissolved for several months. Crushed rock salt is not a chemically pure sodium chloride but contains a number of different salts.

Common salt may be procured very cheaply from the mines or from producers, but usually is purchased as economically from local dealers, who obtain it in carload lots. It usually may be purchased locally from feed stores, ice-cream manufacturers, hide dealers, grocers, and general merchandise stores. It does not require any special containers and may be stored without using any precautions other than to keep it dry.

Granulated sodium chloride was applied to the soil in 8-inch flowerpots in which barberry plants were growing. A number of plants were treated with varying quantities. In a greenhouse test 25 grams of salt was found to be sufficient to kill the plants in 10 days. This was equivalent to 5 pounds of salt applied in the field to each plant of average size. This preliminary greenhouse test was deemed sufficiently satisfactory to warrant extending experimentation to the field.

TABLE 3.-Summary of treatments of individual, marked barberry bushes with sodium chloride

\begin{tabular}{|c|c|c|c|c|c|c|c|c|}
\hline $\begin{array}{c}\text { Date of } \\
\text { treatment }\end{array}$ & $\begin{array}{l}\text { Date of final } \\
\text { observation }\end{array}$ & $\begin{array}{l}\text { Quan- } \\
\text { tity of } \\
\text { chem- } \\
\text { ical } \\
\text { to the } \\
\text { bush }\end{array}$ & $\begin{array}{l}\text { Method of } \\
\text { application }\end{array}$ & $\begin{array}{l}\text { Bushes cut } \\
\text { off or left } \\
\text { standing }\end{array}$ & $\begin{array}{l}\text { Location of } \\
\text { area }\end{array}$ & $\begin{array}{l}\text { Bushes } \\
\text { treated }\end{array}$ & $\begin{array}{l}\text { Bushes } \\
\text { killed }\end{array}$ & $\begin{array}{l}\text { - } \\
\text { Per- } \\
\text { centage } \\
\text { killed }\end{array}$ \\
\hline Apr. 27,1922 & July $\quad 3,1923$ & $\begin{array}{c}\text { Pounds } \\
5.0\end{array}$ & $\begin{array}{l}\text { In circle of } 1 \text { - } \\
\text { foot radius. }\end{array}$ & & $\begin{array}{l}\text { Gurnee, } \\
\text { IIl. }\end{array}$ & 20 & 17 & 85 \\
\hline $\begin{array}{r}\text { Do-........ } \\
\text { Do-...... } \\
\text { Do-....... } \\
\text { Do-...... } \\
\text { Do-...... } \\
\text { July } 10,1922 \\
\text { Do-..... } \\
\text { Oct. } 16,1922 \\
\text { Do- } \\
\text { Oct. } 13,1921\end{array}$ & $\begin{array}{l}\text { _...d do } \\
\ldots \text { do }\end{array}$ & \begin{tabular}{r|}
5.0 \\
10.0 \\
10.0 \\
15.0 \\
15.0 \\
5.0 \\
5.0 \\
5.0 \\
5.0 \\
8.0
\end{tabular} & 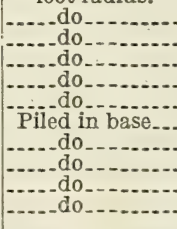 & 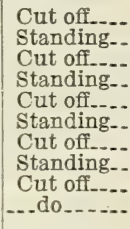 & 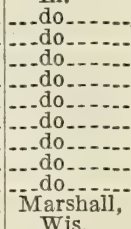 & $\begin{array}{l}20 \\
20 \\
20 \\
20 \\
20 \\
19 \\
20 \\
20 \\
20 \\
25\end{array}$ & $\begin{array}{l}13 \\
19 \\
20 \\
19 \\
20 \\
19 \\
18 \\
20 \\
20 \\
25\end{array}$ & $\begin{array}{r}65 \\
95 \\
100 \\
95 \\
100 \\
100 \\
90 \\
100 \\
100 \\
100\end{array}$ \\
\hline Oct. 31,1921 & July 3,1923 & 8.5 & ......do_. & ...do do & Gurnee, & 47 & 47 & 100 \\
\hline $\begin{array}{l}\text { July } 10,1922 \\
\text { Do- } \\
\text { Oct. } 16,1922 \\
\text { Do- } \\
\text { Oct. } 13,1921\end{array}$ & 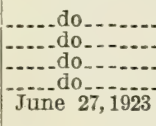 & $\begin{array}{l}10.0 \\
10.0 \\
10.0 \\
10.0 \\
11.1\end{array}$ & & $\begin{array}{l}\text { Standing.- } \\
\text { Cut off-..- } \\
\text { Standing.- } \\
\text { Cut off-..- } \\
\text { Standing.- }\end{array}$ & $\begin{array}{c}\text { do } \\
\text { do do } \\
\text { Marshaill, } \\
\text { Wis }\end{array}$ & $\begin{array}{l}20 \\
20 \\
20 \\
20 \\
18\end{array}$ & $\begin{array}{l}20 \\
20 \\
20 \\
20 \\
18\end{array}$ & $\begin{array}{l}100 \\
100 \\
100 \\
100 \\
100\end{array}$ \\
\hline July 10,1922 & July $\quad 3,1923$ & 15.0 & ......do do & ...do & Gurnee, & 20 & 20 & 100 \\
\hline $\begin{array}{l}\text { Do-- } \\
\text { Oct. } 16,1922 \\
\text { Do- } \\
\text { Oct. } 17,1922 \\
\text { Oct. } 31,1221 \\
\text { Do_..... }\end{array}$ & 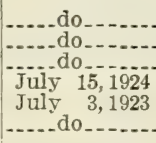 & $\begin{array}{l}15.0 \\
15.0 \\
15.0 \\
16.0 \\
16.2 \\
28.0\end{array}$ & 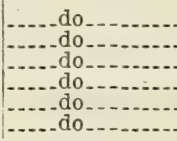 & 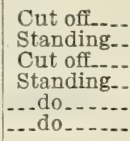 & 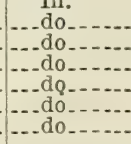 & $\begin{array}{l}20 \\
20 \\
20 \\
50 \\
37 \\
14\end{array}$ & $\begin{array}{l}20 \\
20 \\
20 \\
50 \\
37 \\
14\end{array}$ & $\begin{array}{l}100 \\
100 \\
100 \\
100 \\
100 \\
100\end{array}$ \\
\hline Total & & & & & & 550 & 536 & 97.5 \\
\hline
\end{tabular}


'Table 3 shows that out of 550 marked bushes, treated with dry crushed salt, 536 , or 97.5 per cent, were killed. No sprouts or portions of the bushes designated "killed" were living on the date of final observation, which was from $81 / 2$ to 21 months after treatment. The bushes reported living were partially killed. The only bushes living were among those which received only 5 pounds of salt piled in the base, or to which the salt was applied in a circle 1 foot away from the base. In the latter case, portions of the bush within the circle were not killed, and new sprouts developed from these live parts. No sprouts developed from the lateral roots outside of the circle of salt.

It was apparent that applying the salt to the base of the plant (pl. 11, A) was more effective than applying it in a circle remote from the base; also that 5 pounds of salt applied to the base was not always sufficient to kill the bushes of the size treated. It further appeared that there was little or no difference in the effectiveness of the treatment when applied either to cut or standing bushes (pl. 10, B).

\section{AREA TREATMENTS}

In view of the satisfactory results of these tests, salt was applied to large numbers of bushes growing wild in widely separated areas.

Barberries were growing as escapes from cultivation on the bluffs along the Mississippi River, about 1 mile west of McGregor, Iowa. They occurred on land unsuitable for tillage because of its steepness and numerous limestone outcrops. It was chiefly pasture land, with here and there a few trees, but the barberries constituted the principal shrubby growth. The shrubs were mostly large sprouts from wild bushes that had been cut down and ineffectively dug about two years before the date of treatment. They ranged in size from small individuals of one or two shoots to large clumps 4 or 5 feet in diameter, the average being about 8 inches in diameter at the base.

Approximately 500 bushes were treated with 5,700 pounds of crushed rock salt on October 21, 1922. The salt was hauled to the field in a wagon and distributed to the plants in 10-quart pails. It was heaped in piles about the bases of all stalks, the quantity applied to each bush depending upon its size. The following statement summarizes costs :

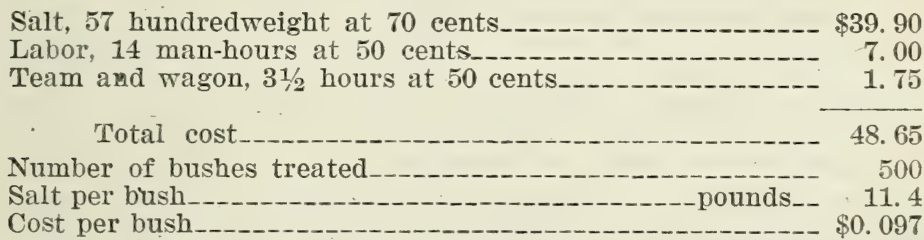

The results of this treatment at McGregor were very satisfactory. The field was inspected in June, 1923, and again later in the summer. The treatment was about 99.5 per cent effective. Several bushes were found alive, but there were indications that they had not been treated. The grass and weeds for a few inches around treated plants were killed and served as an index as to whether or not treatment had been applied. The missed bushes indicated the necessity of using great care to avoid overlooking any plants. The results also indicated that 
even with a chemical 100 per cent effective it would be necessary to reinspect properties where treatments had been made.

Barberry bushes were found in a woodland pasture on a farm 4 miles south of Decorah, Iowa, on gently rolling land with a rich, deep soil. Most of the bushes were in the shade of trees, which caused the shoots to be long and spindling; there were fer shoots to the bush. Along the edge of the wood lot, in a clearing in which the bushes had been cut down three years previous to the date of treatment, sprouts had formed in dense clumps approximately 1 foot in diameter.

Salt was purchased in Decorah, hauled to the wood lot by a farmer, and applied October 6, 1922, in the same manner as at McGregor. The costs were as follows:

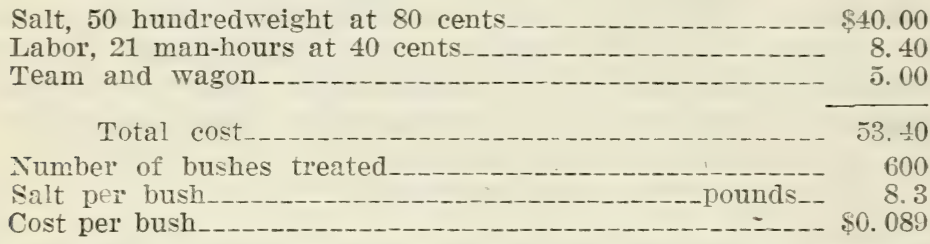

When this area $\pi$ as inspected in the summer of 1923 only 5 liring bushes mere found. so that the treatment of these 600 bushes $\pi$ as orer 99 per cent effective. A considerable number of seedlings that had not been treated were found in the mood lot. This seedling problem will be discussed later in this bulletin.

On a farm near Marshall, Wis., barberries were growing in a level wood lot, among a thick underbrush composed chiefly of prickly ash, rose, hazel, and currant. The soil was rich, deep, black loam. Some of the bushes had been cut down and sprouts had developed, but most of them had not been disturbed preriously. They rere mostly of small size, averaging about 6 inches in diameter at the base. Salt was purchased in bulk at Madison. Wis., and sacked and shipped to Marshall, where it was hauled to the field, distributed in pails, and applied to the indiridual bushes in the manner previously described. The cost was as follows:

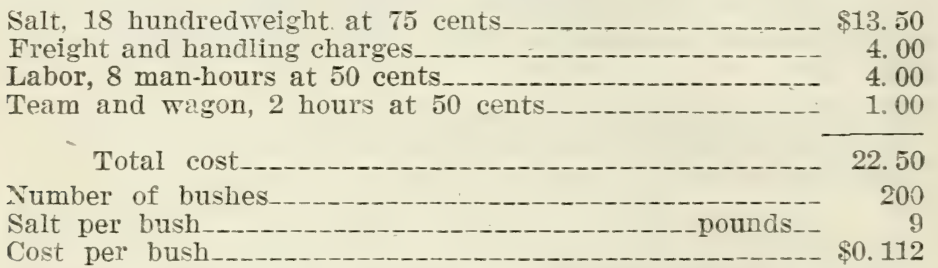

An inspection of this property in the summer of 1923 and again in 1924 disclosed no living bushes showing signs of having been treated with salt. Howerer, there were numerous small plants and seedlings. most of which, no doubt, had been hidden by tall grass and shrubs at the time the salt was applied, and so had been missed. There were indications that salt was nearly 100 рег cent effective when applied in the quantity and manner specified.

On another farm adjoining the one just described, barberries were growing in an open, level, seeded pasture. The bushes had 
been cut down at least three times in different years, the last time being in the spring of 1922. (Pl. 12, A.) This had stimulated the production of many sprouts from both the crown and the injured lateral roots, resulting in thick clumps of considerable diameter and in scattered sprouts. Salt was applied October 28, 1922, in the manner heretofore described. (Pl. 11, B.) The costs were as follows:

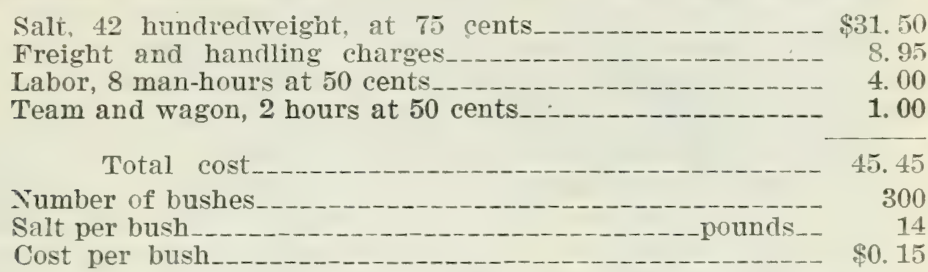

In August, 1923, this property was inspected. Nearly all of the barberries were dead; only two were found living where the grass around them was killed, indicating that salt had been applied. Thus, again, more than 99 per cent of the bushes were killed with salt. Several living sprouts were found showing no dead grass around them. (Pl. 13, A.) Some of these were only 6 inches from dead, treated plants, and when they were dug both living and dead sprouts were traced to the same root. These living sprouts had not developed subsequently to the treatment, but were there at the time and were overlooked. Howerer, as they were but a few inches from a treated sprout, and as the two were attached to the same root, it might have been supposed that killing one would kill the other also, but this was not the case. For purposes of treatment, a barberry bush can not be considered a unit, but each separate shoot must be regarded as a separate entity. In other treatments and in observations on treatments made by many barberry eradicators this fact has been emphasized. Unless every shoot of a barberry clump receires some of the chemical, complete killing can not be expected.

In an area near Huntley, Ill., barberries were growing in a rellgrazed, sodded, level, open wood lot of deep, rich soil where there was little underorowth nther than barberries. The bushes were very uniform in size, being about 2 feet in diameter at the base. In the fall of 1921 the owner had set fire to the accumulation of leaves about their bases, in an attempt to kill them, with the result that most of the old shoots were dead; but there was an abundance of new, vigorous shoots arising from each crown. The bushes were treated October 31, 1922. 'The manner of application did not differ from the preceding except that a slightly smaller quantity of salt was used in proportion to the size of the bushes. The costs were as follows:

Salt, 40 hundredweight, at $971 / 2$ cents.

Labor, 10 man-hours at 50 cents

$\$ 39.00$

Team and wagon, 2 hours at 50 cents

Total cost

Number of bushes

Cost per bush $\$ 0.22 \check{2}$

An inspection of this area in June and again in September, 1923, disclosed that only 3 of the 200 treated bushes were not completely killed. This showed the treatment to be 98.5 per cent effective. Not- 
ing that the average bush was about 2 feet in diameter at the base and that only 20 pounds of salt had been used on each, it was found that less than 7 pounds was used on each square foot of crown area. This was a smaller dose than had been decided on as a result of marked-bush treatments, and therefore some failures might have been expected.

Barberries were planted at Galena, Ill., about 1844, and from these plantings seeds were carried and bushes became established on many of the surrounding farms. On one of the farms there were about 300 bushes, distributed in a pasture on a steep, rocky hillside. A few cedars and hardwood trees also were growing here. During the early part of the summer of 1922 these bushes were cut down and an effort was made to dig them. However, the roots were so firmly and deeply embedded in the limestone outcroppings that the digging was unsuccessful from the standpoint of eradication (pl. $13, \mathrm{~B})$. Within a short time a large number of sprouts had arisen from the broken ends of roots left in the ground, and it was concluded that salt should be applied in an effort to eradicate them. This was done October 24 and 25, 1922. At this time most of the sprouts had attained a height of 6 to 12 inches. In view of the fact that most of the crowns of the original bushes had been removed, the sprouts were very much scattered, and it was necessary to apply much more salt to insure killing than would have been required had the old bushes been leit undisturbed. In the application of the chemical an attempt was made to heap a small quantity around each sprout. The costs were as follows:

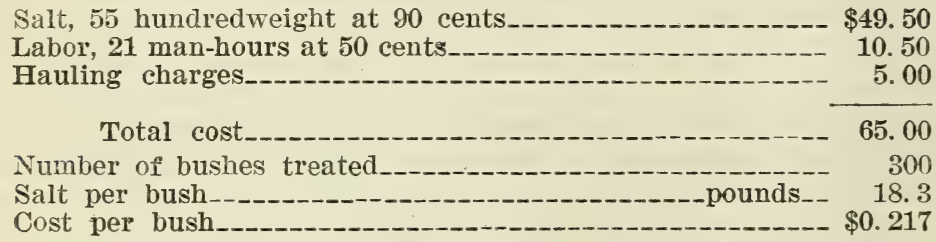

When this area was inspected in June, 1923, many new sprouts were found coming from cut roots that had not sprouted prior to the time of treatment and therefore had not been treated. No living sprouts were found in the treated areas. In this area, as can be seen from Plate 12, B, much salt was applied near cedar trees, some of which were either partially or entirely killed. This was true of some trees that were more than 10 feet from any of the salt.

\section{SODIUM DICHROMATE}

The chromates have not been much used as herbicides, although they are known to be extremely toxic to plants. Rumbold (12) found them to be the most toxic of a considerable number of chemicals injected into chestnut trees. This she found particularly true of potassium dichromate, which, according to her tests, proved to be more toxic than potassium chromate. From this it seemed possible that a dichromate might be an effective poison for barberries. Sodium dichromate $\left(\mathrm{Na}_{2} \mathrm{Cr}_{2} \mathrm{O} 7.2 \mathrm{H}_{2} \mathrm{O}\right)$, which is cheaper than the potassium salt, therefore was selected for trial in the greenhouse.

In greenhouse tests it was found that 5.2 grams, or the estimated equivalent of about 1 pound in the field for an average bush, would 

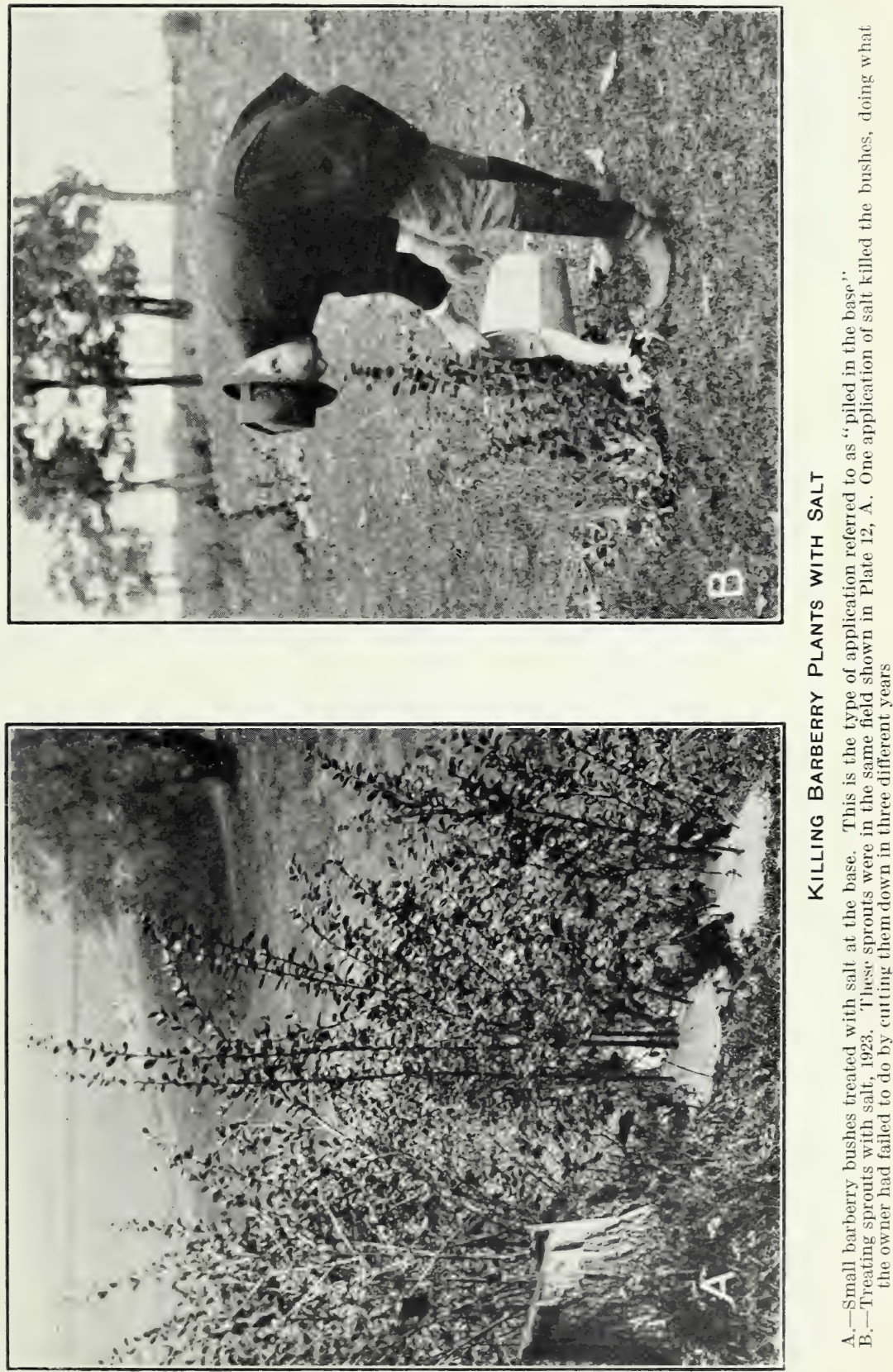

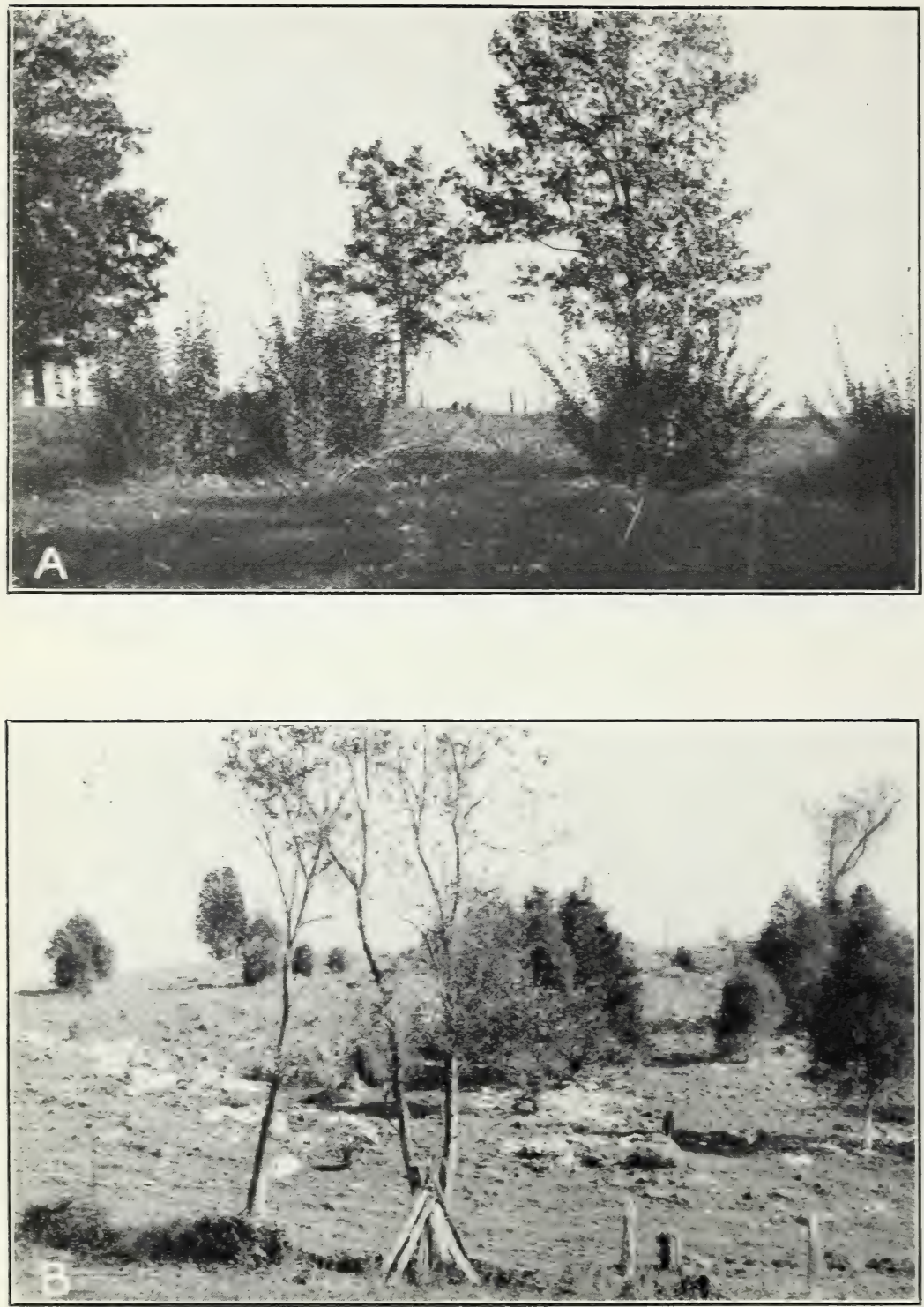

\section{DIGGING COMPARED WITH CHEMICAL TREATMENT}

1.-Barberry sprouts of about three rears' growth near Marshall, Dane County, Wis. (1921). These bushes had been cut down twice. They were cut down a third time in the spring of 1922

B.-Portion of a hillside pasture near Galena. Ill. Here many sprouts were treated with salt, evident as white patches on the ground. The outcropping limestone and the trees and stumps made effective digging almost impossible 

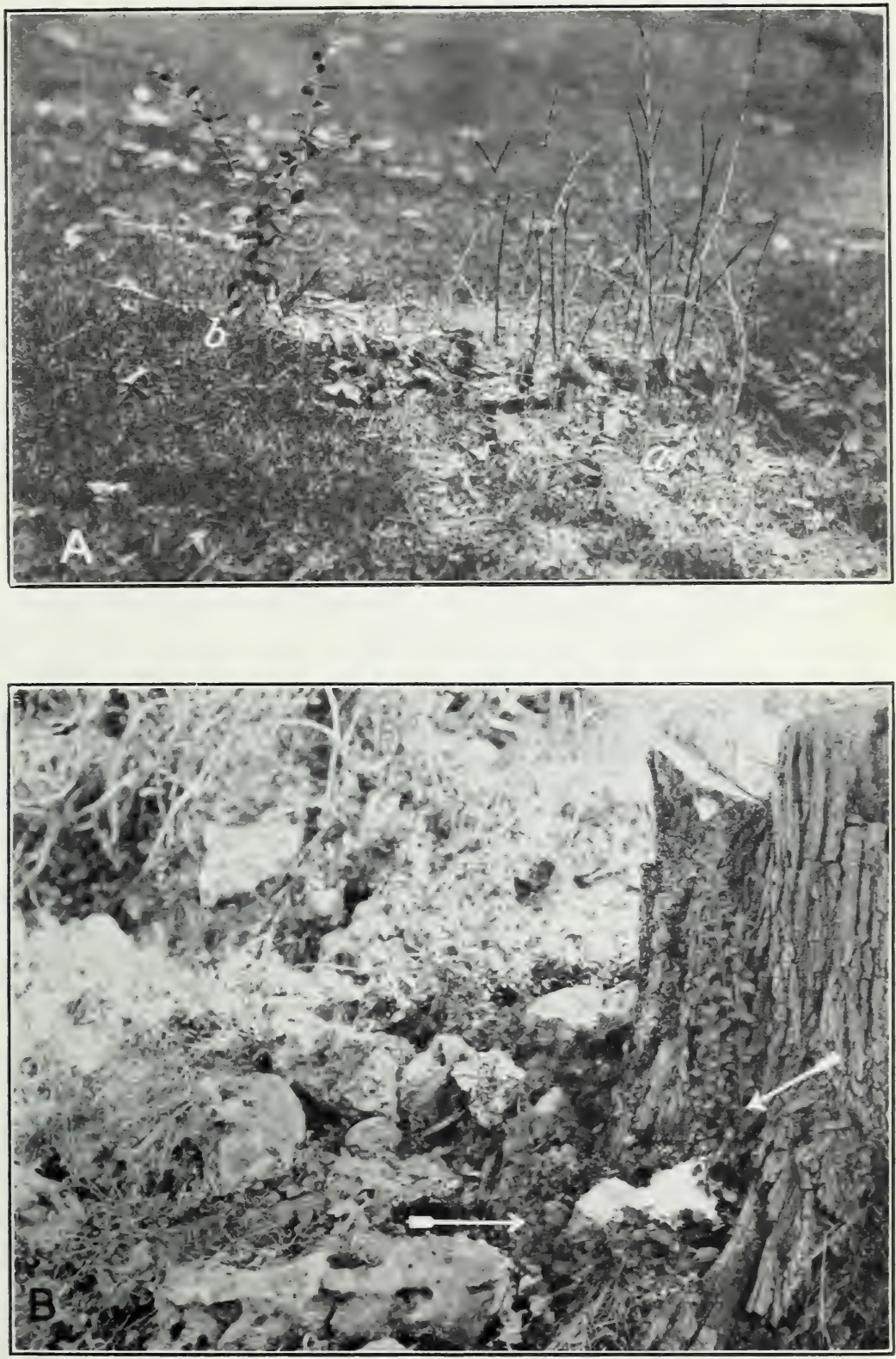

\section{BARBERRY SPROUTS KILLED BY SALT}

A. - The barberry sprouts on the right (a) were killed as a result of an application of salt. The sprout on the left $(b)$ was living, and the condition of the grass showed that no salt had been applied to it

B.-Barberry sprouts growing in a rocky soil near a large stump at Galena, III. Digging in such a location is extremely difficult, but the small application of salt shown in the picture killed all the roots 

kill small barberries growing in 8-inch pots in eight days when sprinkled on the surface of the soil. As this chemical could be purchased for 7 to 8 cents a pound, the results seemed to warrant extending the experiments to the field. Table 4 contains the field results.

TABLE 4.-Summary of treatments of individual, marked barberry bushes with sodium dichromate

\begin{tabular}{|c|c|c|c|c|c|c|c|c|c|}
\hline$\underset{\text { treatment }}{\text { Date of }}$ & $\begin{array}{l}\text { Date of final } \\
\text { observation }\end{array}$ & 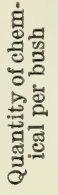 & $\begin{array}{l}\text { Condition of } \\
\text { chemical }\end{array}$ & $\begin{array}{l}\text { Method of } \\
\text { application }\end{array}$ & $\begin{array}{l}\text { Bushes } \\
\text { cut off } \\
\text { or left } \\
\text { standing }\end{array}$ & $\begin{array}{l}\text { Location } \\
\text { of area }\end{array}$ & 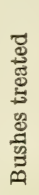 & 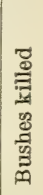 & 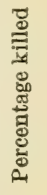 \\
\hline Apr. 18,1922 & June 27,1923 & $\begin{array}{l}\text { Lbs. } \\
1.0\end{array}$ & Dry crystals . & $\begin{array}{l}6 \text { inches deep in } \\
\text { circle of } 1 \text {-foot } \\
\text { radius. }\end{array}$ & Cut off-.. & $\begin{array}{c}\text { Marshall, } \\
\text { Wis. }\end{array}$ & 20 & 6 & 30 \\
\hline $\begin{array}{l}\text { Do. } \\
\text { Apr. } 20,1922\end{array}$ & ..... do - . . . & 1. 0 & -.... do & do do & Standing- & ...do do .... & 20 & 12 & 60 \\
\hline Apr. 20,1922 & - & 1.0 & ........ $00_{-}$ & $\begin{array}{l}2 \text { inches deep in } \\
\text { circle of } 1 \text {-foot } \\
\text { radius. }\end{array}$ & -_. do__. & ...do_..... & 5 & 1 & 20 \\
\hline Do_..... & _......do_.. & 1.0 & ......do do & $\begin{array}{l}2 \text { inches deep in } \\
\text { circle of } 2 \text {-foot } \\
\text { radius. }\end{array}$ & $\ldots$ do _.... & ... do ..... & 5 & 2 & 40 \\
\hline May 20,1922 & July 3,1923 & 1.5 & ..... do & $\begin{array}{l}\text { Scattered on sur- } \\
\text { i a e among }\end{array}$ & ...do do..... & $\begin{array}{l}\text { Gurnee, } \\
\text { III. }\end{array}$ & 10 & 8 & 80 \\
\hline May 5,1923 & Aug. 15,1924 & .2 & $\begin{array}{l}\text { Dissolved in } \\
1 \text { gallon of }\end{array}$ & Drench............ & Cut off.-. & ...do...... & 10 & 0 & 0 \\
\hline Do $\ldots . .$. & - do do & .2 & water. & -..... d d $0_{2}$ & Standing. & ... do_. & 10 & 0 & 0 \\
\hline Oct. 17,1923 & July 15,1924 & .4 & .... do do..... & ..... do ... & Cut aff-.- & ... do & 8 & 4 & 50 \\
\hline May 5,1923 & Aug. 15,1924 & $\begin{array}{l}.4 \\
.4\end{array}$ & Dissolved in & - & $\begin{array}{l}\text { Standing- } \\
\text { Cut off...- }\end{array}$ & -_do do...... & $\begin{array}{r}8 \\
10\end{array}$ & $\begin{array}{l}8 \\
0\end{array}$ & $\begin{array}{r}100 \\
0\end{array}$ \\
\hline Do & ......do do & .4 & $\begin{array}{l}2 \text { gallons of } \\
\text { water. }\end{array}$ & & Standing. & ... do . .... & 10 & 0 & 0 \\
\hline Aug. 10, 1923 & $\ldots \mathrm{do} o_{-}$ & .5 & $\begin{array}{l}\text { Dissolved in } \\
1 \text { gallon of } \\
\text { water. }\end{array}$ & .....do & Cut off... & ...do do...... & 8 & 7 & 88 \\
\hline $\begin{array}{c}\text { Do. } \\
\text { Sept.10,1923 }\end{array}$ & .....do_._..... & .5 & .... do do...... & .... do & Standing- & ... do do..... & 8 & 5 & 62 \\
\hline $\begin{array}{l}\text { Sept.10, } 1923 \\
\text { Do_. }\end{array}$ & do do & .5 & do do & ..... do do & $\begin{array}{l}\text { Cut off-- - } \\
\text { Standing- }\end{array}$ & 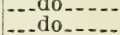 & $\begin{array}{l}10 \\
10\end{array}$ & $\begin{array}{l}10 \\
10\end{array}$ & $\begin{array}{l}100 \\
100\end{array}$ \\
\hline Oct. 17,1922 & July 15,1924 & .8 & $\begin{array}{l}\text { Dissolved in } \\
2 \text { gallons of } \\
\text { water. }\end{array}$ & do & Cut off--- & do do & 8 & 7 & 88 \\
\hline $\begin{array}{l}\text { Do- } \\
\text { July } 3,1923\end{array}$ & ....do_....... & .8 & ....do_. & _. _do do & Standing- & ...do . & 10 & 10 & 100 \\
\hline July 3,1923 & Aug. 15,1924 & 1.0 & $\begin{array}{l}\text { Dissolved in } \\
1 \text { gallon of } \\
\text { water. }\end{array}$ & ......do & Cut off.-. & & 10 & 10 & 100 \\
\hline $\begin{array}{l}\text { Do. } \\
\text { Sept. 10, } 1923\end{array}$ & -...-do_....... & 1.0 & ..... do ....... & _.... do do & Standing- & ...do..... & 10 & 10 & 100 \\
\hline $\begin{array}{l}\text { Sept. 10, } 1923 \\
\text { Do }\end{array}$ & -ado do & $\begin{array}{l}1.0 \\
1.0\end{array}$ & -....dodo do & - & $\begin{array}{l}\text { Cut off--. } \\
\text { Standing- }\end{array}$ & - & $\begin{array}{l}10 \\
10\end{array}$ & $\begin{array}{l}10 \\
10\end{array}$ & $\begin{array}{l}100 \\
100\end{array}$ \\
\hline Total. & & & & & & & 210 & 130 & 62 \\
\hline
\end{tabular}

The first conclusion reached from the experiments reported in Table 4 was that dry sodium dichromate applied in a ring around the base of a barberry bush was relatively ineffective. The second conclusion was that the application of dry crystals of the chemical directly to the ground in and around the base of the shoots was not satisfactory. However, this is open to question, as bushes of but one series were so treated. The decision was somewhat influenced by the results obtained with sodium aisenite, as reported elsewhere in this bulletin, and hence attention was turned to the use of sodium dichromate in solution. Doses from 0.2 to 1 pound of the chemical dissolved in 1 or 2 gallons of water were tried. The results show that all bushes which received a drench of 1 pound dissolved in 1 gallon 
of water were killed. However, it should be noted that all of these treatments were applied in July and September, and that half a pound in 1 gallon was equally effective in September, whereas 0.4 of a pound in 2 gallons applied in May did not kill any bushes. It may be that the barberry is more susceptible to sodium dichromate late in summer or that the amount of soil moisture at time of treatment is the controlling factor.

By the time these results were obtained, other chemicals (sodium (hloride, kerosene, and sodium arsenite) had proved so satisfactory that the experiment was discontinued. It is believed, however, that sodium dichromate as a herbicide deserves further study. It is easy and safe to handle and is relatively cheap when bought in bulk. It was quoted to the writers at 7 to 8 cents a pound. Transportation costs would be low.

Relatively small quantities of sodium dichromate seem to be sufficient to cause death in plants. Its extreme toxicity to trees when injected into the trunk also suggests that it may be of value in landclearing operations to replace sodium arsenite, the extremely poisonous nature of which makes its use inadvisable.

\section{KEROSENE ACID SLUDGE (SULPHURIC ACID)}

Kerosene acid sludge is a heavy, dark-colored, oily liquid containing a considerable quantity of sulphuric acid. It is a by-product from the refining of kerosene and may be obtained from refineries. The price quoted was 7 cents a gallon; however. as it must be shipped in glass carboys or other acid-proof containers, the trans. portation costs are considerable.

In the greenhouse 40 cubic centimeters of kerosene acid sludge, applied to the soil surface in 8-inch pots containing small barberries, killed the plants in three days. This dose was the estimated equivalent of about 0.9 of a gallon to a mid-sized bush in the field. Table 5 gives the results of the field treatments.

TABLE 5.-Summary of treatments of individual, marked barberry bushes uith kerosene acid sludge (sulphuric acid)

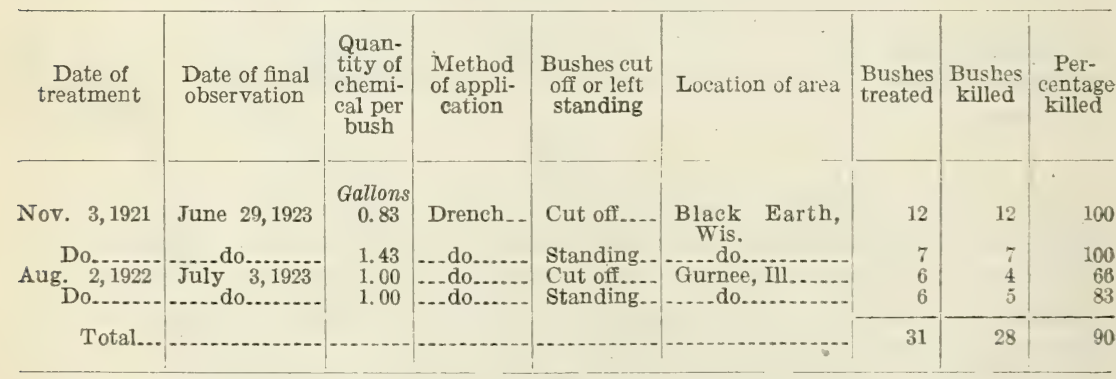

As may be seen, 90 per cent of the 31 bushes treated were killed. Of the three that survived the old crowns were entirely killed. but sprouts arose from the large lateral roots just outside of the area to which the chemical was applied. Kerosene acid sludge is extremely corrosive, destroying any organic material that it touches. It is possible that its killing power is due chiefly to this property and that 
little or none of the material is absorbed by the plant. In this case its action might well be compared to burning the plant, which in the case of barberries is very ineffective. The difficulty and danger connected with handling a strong acid, however, were the principal reasons for discarding this chemical.

\section{PHENOL}

Pure phenol or carbolic acid $\left(\mathrm{C}_{6} \mathrm{H}_{5} \mathrm{OH}\right)$ is a white, crystalline substance. It is used extensively in solution as a disinfectant, but has not been generally used as a herbicide. Jones and Orton (8) experimented with it for this purpose in 1899 , and others have since used it to a limited extent. United States Pharmacopoia phenol was quoted at 14 cents a pound in 950-pound drums, while crude phenol (15 per cent grade) was quoted at 35 cents a gallon in wooden barrels. The crude phenol contains some cresols and other impurities.

In the greenhouse, 3 grams of chemically pure phenol applied to the surface of the soil in 8-inch pots containing small barberries caused the death of the plants in 14 days. The results of field experiments are shown in Table 6.

TABLE 6.-Summary of treatments of individual, marked barberry bushes with phenol

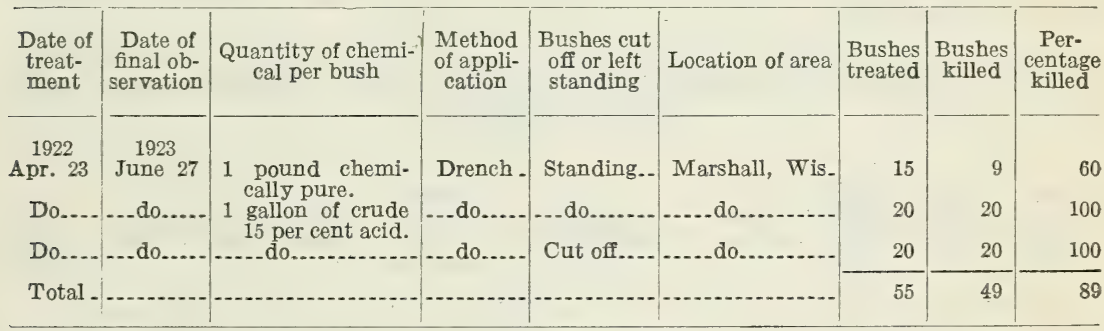

It is evident from an examination of Table 6 that sufficient experimentation was not done with phenol to warrant any definite conclusions. One gallon of the crude acid produced 100 per cent fatality, but at 35 cents a gallon at the shipping point the cost would be prohibitive. Probably a smaller quantity would have given equally satisfactory results. The principal reasons for discontinuing the experiments were (1) the favorable results which were being obtained with other chemicals and (2) the difficulties of handling carbolic acid in large quantities. The danger to the clothes as well as to the persons of those handling it is considerable and must be taken into aceount.

\section{PICRIC ACID}

Picric acid (trinitrophenol, $\mathrm{C}_{6} \mathrm{H}_{2}\left(\mathrm{NO}_{2}\right)_{3} \mathrm{OH}$ ) is poisonous to animals and also is an explosive. As large quantities were available at the end of the war, the.possibilities of its value as a herbicide were worth investigating. Experiments in the greenhouse, however, resulted unsatisfactorily, and field tests were not made. In the greenhouse 200 cubic centimeters of a saturated solution applied to the soil in an 8-inch pot of small barberries failed to kill the plants. 
The picric acid was quoted in large quantities at 20 to 25 cents a pound. At this rate a field application as strong as that which failed in the greenhouse would cost about 15 cents for the material alone. Hence, a stronger and fatal dose would be prohibitive in cost.

\section{SULPHUR (INOCULATED)}

Tests were made with a commercial preparation of inoculated sulphur containing bacteria intended to hasten the oxidation and solution of the sulphur when applied to soils in whieh such bacteria might be deficient. The sulphur was in the form of a powder and, when applied to the soil, went into solution slowly, making the soil very acid. Just what the action on the plant may be is not known. It may be merely the toxic effects of an acid soil, or it may be a more direct action of the sulphur.

No greenhouse tests were made with this material. The most effective method of application in the field would seem to be to work the sulphur into the soil around the plants to be treated. It was decided that such a method would be too expensive to consider. Instead, a quantity of the sulphur was mixed with moist earth and the mixture was applied to the surface of the soil near the base of the bush. It was then stamped, to work it down through the grass and into contact with the soil. Table 7 gives the results of the sulphur treatments.

TABLE 7.-Summary of treatments of individual, marked barberry bushes with inoculated sulphur

\begin{tabular}{|c|c|c|c|c|c|c|c|c|c|}
\hline $\begin{array}{l}\text { Date } \\
\text { of } \\
\text { treat- } \\
\text { ment }\end{array}$ & $\begin{array}{l}\text { Date of } \\
\text { final } \\
\text { observa- } \\
\text { tion }\end{array}$ & $\begin{array}{l}\text { Quan- } \\
\text { tity of } \\
\text { chemi- } \\
\text { cal per } \\
\text { bush }\end{array}$ & $\begin{array}{l}\text { Dilution } \\
\text { with soil }\end{array}$ & $\begin{array}{l}\text { Method of } \\
\text { application }\end{array}$ & $\begin{array}{l}\text { Bushes } \\
\text { cut off } \\
\text { or left } \\
\text { standing }\end{array}$ & $\begin{array}{c}\text { Location } \\
\text { of area }\end{array}$ & $\begin{array}{l}\text { Bushes } \\
\text { treated. }\end{array}$ & $\begin{array}{l}\text { Bushes } \\
\text { killed }\end{array}$ & $\begin{array}{l}\text { Per- } \\
\text { cent- } \\
\text { age } \\
\text { killed }\end{array}$ \\
\hline $\mathrm{July}_{3}^{1923}$ & $\stackrel{\text { May }}{1925}^{192}$ & Pounds & 1 to 4 & Around crown on & Cut off... & Gur & 5 & 5 & 100 \\
\hline Do... & $\ldots$ do $\ldots . .$. & 1.0 & 1 to 4 & surface & Standing. & IIl. & 5 & 5 & 100 \\
\hline Sept. 10 & ...................... & 1. 0 & 1 to 4 & ........do... & Cut off... & do & 5 & & 100 \\
\hline Do... & ...do...... & 1.0 & 1 to 4 & do. & Standing & ...do....... & 5 & 4 & 80 \\
\hline June 8 & ...do...... & 1.4 & 1.4 to 8 & -. do _ & Cut off -.- & ....do...... & 5 & 3 & 60 \\
\hline Do... & ...do...... & 1.4 & 1.4 to 8 & -_do & Standing. & ... do do...... & 5 & 5 & 100 \\
\hline & ... do & 20 & 1 to 4 & -. do & Cut off-.- & ...do..... & 5 & 5 & 100 \\
\hline & . do & 2.0 & 1 to 4 & do & Standing. & do do....... & 5 & 0 & \\
\hline Total. & & & & & & & 40 & 32 & 80 \\
\hline
\end{tabular}

One thing is not shown in the table, however; that is the extreme slowness with which the sulphur acted. The following notes taken from the writers' field book illustrate this:

July 3, 1923. Treated fire standing bushes with sulphur, 1 pound to 4 pounds of earth.

August 10, 1923. No apparent injury to three bushes. Two bushes show a slight yellowing of some leaves.

September 10,1923 . No noticeable injury.

September 20,1923 . No noticeable injury.

July 14, 1924. New growth which is dying, on all plants. All the leaves on some stems are dead and on others there is partial injury to some leaves.

August 15, 1924. Two plants dead; others look very sick.

May 22, 1925. Bushes all dead. 
When the bushes were cut down before being treated, the stumps sprouted in nearly every case. The sprouts grew well for several months before there was noticeable injury, and not until the second year was it evident that many of them would not survive.

\section{CALCIUM CARBIDE}

Calcium carbide $\left(\mathrm{CaC}_{2}\right)$, when moistened, forms acetylene gas $\left(\mathrm{C}_{2} \mathrm{H}_{2}\right)$, which frequently is used for illuminating purposes and for welding or cutting metal. This gas has been reported to be very toxic to plants.

On October 31, 1921, 36 mid-sized barberries growing in the field at Gurnee, Ill., were treated with calcium carbide at the rate of about $23 / 4$ pounds to the bush. Several holes about 10 inches deep were made with a crowbar around the base of each bush, and the carbide was inserted; then the holes were filled with earth and tamped. Twenty-one of the bushes were left standing and 15 were cut down before treating. None were dead at the time of the final observation, 21 months later.

On April 28, 1922, 40 bushes in the same locality were treated in the same manner but with a dose of only $2 \frac{1}{2}$ pounds to the bush. Half of these bushes were cut down and the other half left standing. Thirteen months later 2 of the 20 that had been cut down were dead, but all the others were living and apparently uninjured.

Evidently acetylene gas is not very toxic to common barberries or else the method of application used was not such as to permit the gas to reach the living tissues of the plants. No further experiments were made with this substance.

\section{CALCIUM CYANIDE}

The commercial calcium cyanide used was obtained from a manufacturer and was said to contain about 45 per cent of calcium cyanide $\left(\mathrm{Ca}(\mathrm{CN})_{2}\right)$, 30 per cent of sodium chloride, 12 per cent of lime, and a small proportion of graphite and other inert ingredients. This chemical has been reported as a very effective herbicide when sprinkled on the surface of moist ground and covered with paper, straw, or similar materials, in order to retain the hydrocyanic gas evolved. As such a procedure was scarcely feasible with large numbers of barberry bushes, the cyanide was placed in holes about 6 inches deep and close about the crown of the bush. (Table 8.)

TABLE 8.-Summary of treatments of individual, marked barberry bushes with calcium cyanide

\begin{tabular}{|c|c|c|c|c|c|c|c|c|}
\hline $\begin{array}{l}\text { Date of } \\
\text { treat- } \\
\text { ment }\end{array}$ & $\begin{array}{c}\text { Date of } \\
\text { final } \\
\text { observa- } \\
\text { tion }\end{array}$ & $\begin{array}{c}\text { Quan- } \\
\text { tity of } \\
\text { chemi- } \\
\text { cal per } \\
\text { bush }\end{array}$ & Method of application & $\begin{array}{l}\text { Bushes } \\
\text { cut off } \\
\text { or left } \\
\text { standing }\end{array}$ & $\begin{array}{l}\text { Location } \\
\text { of area }\end{array}$ & $\begin{array}{l}\text { Bushes } \\
\text { treated }\end{array}$ & $\begin{array}{c}\text { Bushes } \\
\text { killed }\end{array}$ & $\begin{array}{l}\text { Per- } \\
\text { cent- } \\
\text { age } \\
\text { killed }\end{array}$ \\
\hline 1923 & 1924 & Pounds & - & & & & & \\
\hline Aug. 10 & July 14 & 0.25 & In holes about crown... & Standing.- & Gurnee, IIl.- & 5 & 1 & 20 \\
\hline Do & ... do do..... & .25 & -.... do do & Cut off-..-. & ...... do do........ & 5 & 0 & 80 \\
\hline $\begin{array}{l}\text { Sept. } 10 \\
\text { Do.... }\end{array}$ & ...do do...... & $\begin{array}{l}.75 \\
.75\end{array}$ & - & $\begin{array}{l}\text { Standing.- } \\
\text { Cut off.-.- }\end{array}$ & (.....do do........... & $\begin{array}{l}5 \\
5\end{array}$ & $\begin{array}{l}4 \\
0\end{array}$ & $\begin{array}{r}80 \\
0\end{array}$ \\
\hline Total_ & & & & & & 20 & 5 & 25 \\
\hline
\end{tabular}


It is evident that this method of application is inefficient. The quantity of the material used for a bush unquestionably was sufficient to cause the death of the bush, if the hydrocyanic-acid gas had been liberated and allowed to act on the roots. Death did not result in every case. This deficiency may have been due to some peculiarity of the soil or of root conditions of the particular bushes that prevented the gas from reaching all the roots, or to the failure of hydrocyanic-acid gas to remain free in the soil.

\section{CARBON BISULPHIDE}

Carbon bisulphide $\left(\mathrm{CS}_{2}\right)$ at ordinary temperatures is a heavy liquid which vaporizes readily. The vapor is heavier than air and readily penetrates soil that is not too wet. It has been used to some extent as a herbicide, as for instance by Wilcox (18), but it has had a greater use as an insecticide. Hinds (6) states that it kills insects by dissolving fats, coagulating proteins, and preventing the assimilation of oxygen.

In the greenhouse 2.6 grams of carbon bisulphide applied to the surface of the soil in 8-inch pots of small barberries caused the death of the plants in eight days. This was considered equivalent to a dose of about one-half pound to the bush in the field. As the material could be purchased for about 6.5 cents a pound, it was tried in the field. In Table 9 the results of the field tests are given.

TABLE 9.-Summary of treatments of individual, marked barberry bushes with carbon bisulphide

\begin{tabular}{|c|c|c|c|c|c|c|c|c|}
\hline $\begin{array}{l}\text { Date of } \\
\text { treat- } \\
\text { ment }\end{array}$ & $\begin{array}{l}\text { Date of } \\
\text { final ob- } \\
\text { servation }\end{array}$ & $\begin{array}{l}\text { Quan- } \\
\text { tity of } \\
\text { chemi- } \\
\text { cal per } \\
\text { bush }\end{array}$ & Method of application & $\begin{array}{l}\text { Bushes cut } \\
\text { off or left } \\
\text { standing }\end{array}$ & $\begin{array}{l}\text { Location of } \\
\text { area }\end{array}$ & $\begin{array}{l}\text { Bushes } \\
\text { treated }\end{array}$ & $\begin{array}{c}\text { Bushes } \\
\text { killed }\end{array}$ & $\begin{array}{l}\text { Per- } \\
\text { centage } \\
\text { killed }\end{array}$ \\
\hline $\operatorname{May}_{9}^{1922}$ & $\begin{array}{c}\text { July } \\
\text { Jug } \\
\text { ge }\end{array}$ & $\begin{array}{r}\text { Pints } \\
1.00\end{array}$ & $\begin{array}{l}\text { Poured in four holes, } 8 \\
\text { inches deep, around } \\
\text { crown. }\end{array}$ & Standing.. & Gurnee, Ill. & 20 & 17 & 85 \\
\hline $\begin{array}{l}\text { Do.... } \\
\text { Do... }\end{array}$ & ...do..... & 1.00 & do & Cut off..... & ......do...... & 20 & 15 & \\
\hline Do.... & (...do do.... & $\begin{array}{l}2.00 \\
2.00\end{array}$ & -...-do do & $\begin{array}{l}\text { Standing.. } \\
\text { Cut off.... }\end{array}$ & $\ldots . . .-d$ & 20 & $\begin{array}{l}10 \\
13\end{array}$ & $\begin{array}{l}80 \\
65\end{array}$ \\
\hline July 10 & $\ldots$ do & 1.00 & In circle of 1 -foot radius & Standing.. & ................ & 20 & 18. & 90 \\
\hline May 9 & ...do.... & 1.00 & Drench in and around & ...do_.... & ............. & 5 & 4 & 80 \\
\hline $\begin{array}{l}\text { July } 10 \\
\text { Oct. } 16\end{array}$ & $\mid \begin{array}{l}\ldots \text { do..... } \\
\ldots . . \text { do } \ldots . . .\end{array}$ & $\begin{array}{l}1.00 \\
1.75\end{array}$ & do & $\begin{array}{l}\text { Cut off.... } \\
\text { Standing.. }\end{array}$ & ...do do & $\begin{array}{l}20 \\
90\end{array}$ & $\begin{array}{l}20 \\
77\end{array}$ & $\begin{array}{r}100 \\
86\end{array}$ \\
\hline Total. & & & & & & 215 & 180 & 84 \\
\hline
\end{tabular}

It appears from these results that 1 pint is as efficient in kiliing barberries as 2 pints, also that carbon bisulphide is equally effective when poured on the surface of the soil and when applied in holes around the crown. Though a large percentage of the bushes treated were killed, in only one case were all the bushes of a treatment killed. These differences no doubt were due to the type and physical "ondit on of the soil around individual bushes, as well as to variations of the root system. In light, dry soil carbon bisulphide diffnses rapidly, but in heavy, wet soil the diffusion is slow. A satis- 
\actory chemical for eradicating barberries must be effective in various types of soil and under various weather conditions. It did not appear worth while to make a more critical study of the factors favoring the action of carbon bisulphide.

One other fact should be mentioned. Of all the chemicals tried in the wood lot nea: Gurnee, Ill., carbon bisulphide did the most damage to the trees near the treatments. One large cherry tree and two oaks were killed. These trees had trunks from 6 to 10 inches in diameter and were 8 to 10 feet from the treated barberry plants.

\section{PARADICHLOROBENZENE}

Paradichlorobenzene $\left(\mathrm{C}_{6} \mathrm{H}_{4} \mathrm{Cl}_{2}\right)$ is a white crystalline substance. It is used to a cons:derable extent as a substitute for naphthalene and other moth repellents. It also has been successfully used for ixilling peach-tree borers. Blakeslee (1) and others have reported that, when it is used to kill borers in the crown of the tree, injury or death of the tree is likely to result when a large dose is used. As the dosage for killing borers is 1 ounce or less to the tree, it seemed probable that this substance in larger quantities might be an efficient herbicide. Guyton and Stear (5) suggest designating paradichlorobenzene as PDB.

In the greenhouse in experiments with barberries in 8-inch pots a dose of 5.2 grams per pot caused discoloration and dropping of the leaves, but the roots apparently were healthy one month after the treatment. An application of 1.25 grams dissolved in 20 cubic centimeters of kerosene and applied to a plant killed the tops of the plant, but two months after the application the roots were still healthy in appearance.

In the field, treatments were made on two different dates at Marshall, Wis. On December 10,1921, 10 barberries were treated with one-fourth of a pound each. 'Half of the bushes were cut down and the others were left standing. The chemical was placed in a trench 5 inches deep and close to the crowns of the bushes. No injury to the plants was noted the following year, and on July $2 \overline{7}, 1923$, they apparently were healthy.

The second treatment was made on April 20, 1922, when 18 bushes were treated with 1 pound each. Here also half had been previously cut down. The chemical was placed in a trench 3 inches deep close to the crown and covered with earth. No apparent injury resulted to any of these bushes.

\section{SODIUM CYANIDE}

Sodium cyanide $(\mathrm{NaCN})$ in the form of crystals was applied to the soil in 8-inch pots of barberries. Death of the plants was caused in eight days by 5.2 grams sprinkled on the surface of the soil. Although this was a very satisfactory showing, the cost of the chemical was such that no field tests were made. Calcium cyanide was tried in the field, however.

\section{AMMONIUM PICRATE}

Ammonium picrate $\left(\mathrm{C}_{6} \mathrm{H}_{2}\left(\mathrm{NO}_{2}\right)_{3} \mathrm{ONH}_{4}\right)$ in crystal form was applied to potted barberries growing in the greenhouse. Applications of 5.2 grams to the surface of the soil in an 8-inch pot failed to 
injure appreciably the barberries growing in the pot. This was considered equivalent to an application of 1 pound to a barberry bush growing in the field. As this quantity failed to kill the plants and as much larger applications would be prohibitive in cost, no further experiments were made with this chemical.

\section{BENZENE}

Benzene $\left(\mathrm{C}_{6} \mathrm{H}_{6}\right)$ was applied to the surface of the soil in 8-inch pots in which small barberries were growing. An application of 7 cubic centimeters injured the plants materially, but the results were very slow in appearing and the plants eventually recovered. This was the equivalent of about 1.4 pounds applied to a bush in the field. At a cost of 30 cents a pound a larger application than this would be prohibitive in price, and for this reason no further experiments were performed with this substance.

\section{CREOSOTE OIL (LIGHT)}

Creosote oil is a coal-tar product and is used as a wood preservative. The material obtained was a light oil that penetrated the soil readily. It was quoted at 15 cents per gallon.

In the greenhouse, 42 cubic centimeters applied to the soil in 8-inch pots in which barberries were growing killed the plants in 18 days.

One treatment was made in the field at Marshall, Wis. Fourteen barberry bushes were treated with 1 gallon each, applied as a drench to the base of the shoots, which were left standing. The treatment was made on May 1, 1922; and on June 27, 1923, 11 plants or 79 per cent were dead. The action of the chemical was very rapid, and the bushes that survived were severely injured. Although the results were fairly good, they did not equal those obtained from some of the other chemicals. As this material is not so readily available nor so cheap as some others, no further tests were made.

\section{METACRESOL}

Metacresol $\left(\mathrm{C}_{6} \mathrm{H}_{4} \mathrm{CH}_{3} \mathrm{OH}\right)$ is a light liquid that can be purchased in quantity at about 15 cents a pound. In greenhouse experiments 8 cubic centimeters caused the death of barberries in 8-inch pots in seven days. This was a very satisfactory showing except that the cost was high. No field experiments were made with this chemical, although the results of the greenhouse tests would seem to warrant further trials.

\section{DICHLOROBENZENE (MIXED)}

The dichlorobenzene $\left(\mathrm{C}_{6} \mathrm{H}_{4} \mathrm{Cl}_{2}\right)$ was a mixture of the ortho and meta forms. It is a light liquid which can be purchased in quantity for about 10 cents a pound. In the greenhouse 12 cubic centimeters caused the death of the plants in 12 days. Although this result was fairly satisfactory, no field tests were made with this substance. Though many of the less common organic compounds may be efficient herbicides, the difficulty of procuring them in large quantity and at short notice is so great that unless they show very exceptional herbicidal qualities it is scarcely worth while to consider them from a practical viewpoint. 
PETROLEUM FUEL OIL

Petroleum fuel oil is a heavy oil obtained by the fractional distillation of petroleum. It was quoted at $\tau$ cents a gallon and probably could be procured on short notice in most parts of the country at a very satisfactory price.

No greenhouse tests were made with this substance, but the results. of the field tests are given in Table 10.

TABLE 10.-Summary of treatments of individual, marked barberry bushes with petroleum fuel oil

\begin{tabular}{|c|c|c|c|c|c|c|c|c|}
\hline $\begin{array}{l}\text { Date of } \\
\text { treatment }\end{array}$ & $\begin{array}{l}\text { Date of final } \\
\text { observation }\end{array}$ & $\begin{array}{l}\text { Quan- } \\
\text { tity of } \\
\text { chemi- } \\
\text { cal per } \\
\text { bush }\end{array}$ & $\begin{array}{l}\text { Method } \\
\text { of appli- } \\
\text { cation }\end{array}$ & $\begin{array}{l}\text { Bushes cut } \\
\text { off or left } \\
\text { standing }\end{array}$ & Location of area & $\begin{array}{l}\text { Bushes } \\
\text { treated }\end{array}$ & $\begin{array}{l}\text { Bushes } \\
\text { killed }\end{array}$ & $\begin{array}{l}\text { Per- } \\
\text { centage } \\
\text { killed }\end{array}$ \\
\hline 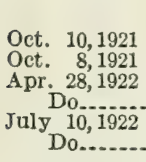 & 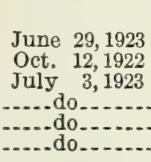 & $\begin{array}{r}\text { Gallons } \\
1.0 \\
1.0 \\
1.0 \\
1.0 \\
1.0 \\
1.0\end{array}$ & 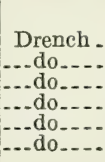 & $\begin{array}{l}\text { Standing.. } \\
\text { Cut off.... } \\
\text { Standing.. } \\
\text { Cut off...- } \\
\text { Standing.- } \\
\text { Cut off...- }\end{array}$ & $\begin{array}{l}\text { Black Earth, Wis. } \\
\text { Gurnee, ili........ } \\
\\
\end{array}$ & $\begin{array}{l}10 \\
10 \\
25 \\
25 \\
20 \\
20\end{array}$ & $\begin{array}{r}6 \\
8 \\
15 \\
22 \\
15 \\
17\end{array}$ & $\begin{array}{l}60 \\
80 \\
60 \\
88 \\
75 \\
85\end{array}$ \\
\hline Total. & & & & & & 110 & 83 & 75 \\
\hline
\end{tabular}

An examination of Table 10 shows that there were but slight differences in the results of treatments in April, July, and October. None of the treatments were very satisfactory, a fact apparently due to the failure of the oil to penetrate the soil any great distance. It spread over the soil but penetrated to a depth of only 3 to 4 inches. Two years after the treatments the soil was still black and caked with the oil. Those portions of the barberry plants actually reached by the oil were killed in most instances, but sprouts developed around the border of the area treated, and a few of the shoots which were actually reached by the oil were not killed. As with the other petroleum oils studied, the action of this oil was very slow.

\section{FURFURAL (FURFURALDEHYDE)}

Furfural $\left((\mathrm{CH})_{3} \mathrm{OCCOH}\right)$ is a thin, brown liquid with a not unpleasant, sweetish odor. It is made from oat hulls, corn husks, and other material. At present the supply is somewhat limited, and it sells for about 35 cents a gallon. With the development of nses for it, large quantities could easily be manufactured and the cost considerably reduced.

In the greenhouse furfural appeared to be a very effective weed killer, as $21 / 2$ cubic centimeters applied to the soil in 8 -inch pots containing small barberries killed five out of six within two weeks after the application. Applications of large quantities killed all plants treated.

Field trials were made on three dates in the summer of 1924, and, as shown in Table 11, the results were very satisfactory. Applications of 1 quart or more per bush were 100 per cent effective. 
TABLE 11.-Summary of treatments of individual, marked barberry bushes with furfural

\begin{tabular}{|c|c|c|c|c|c|c|c|c|}
\hline $\begin{array}{l}\text { Date of } \\
\text { treat- } \\
\text { ment }\end{array}$ & $\begin{array}{c}\text { Date of } \\
\text { final } \\
\text { observa- } \\
\text { tion }\end{array}$ & $\begin{array}{l}\text { Quantity } \\
\text { of chemi- } \\
\text { cal per } \\
\text { bush }\end{array}$ & $\begin{array}{l}\text { Method of } \\
\text { application }\end{array}$ & $\begin{array}{l}\text { Bushes cut off or } \\
\text { left standing }\end{array}$ & Location of area & $\begin{array}{l}\text { Bushes } \\
\text { treated }\end{array}$ & $\begin{array}{l}\text { Bushes } \\
\text { killed }\end{array}$ & $\begin{array}{l}\text { Per- } \\
\text { centage } \\
\text { killed }\end{array}$ \\
\hline $\mathrm{July}_{15}^{1924}$ & 1925 & Pints & & & & & & \\
\hline $\begin{array}{l}\text { July } 15 \\
\text { Aug. } 15\end{array}$ & $\begin{array}{l}\text { May } 22 \\
\ldots . . \text { do...... }\end{array}$ & $\begin{array}{l}1 \\
1\end{array}$ & Drench. & ..... do..... & Gurnee, 11 & $\begin{array}{l}5 \\
5\end{array}$ & $\begin{array}{l}4 \\
4\end{array}$ & $\begin{array}{l}80 \\
80\end{array}$ \\
\hline Oct. 17 & ...do...... & 1 & .....do... & $\ldots . . .$. do & .............. & 5 & 5 & 100 \\
\hline July 15 & . do... & 1 & .....do do... & Standing.- & ........... & 5 & 3 & 60 \\
\hline Aug. 15 & . & 1 & $\ldots . . . \mathrm{do}_{2}$ & ......do..... & ................ & 5 & 4 & 80 \\
\hline Oct. 17 & . do... & 1 & ......do.. & ......do.... & ......do... & 5 & 4 & 80 \\
\hline July 15 & do & 2 & ...... do... & Cut off..... & ....... do & 5 & 5 & 100 \\
\hline Aug. 15 & . do.. & 2 & .....do.. & .....do.... & ..... do... & 5 & 5 & 100 \\
\hline Oct. 17 & . do... & 2 & ....... do... & $\ldots$ do............. & ........ do & 5 & 5 & 100 \\
\hline Julv 15 & do. & 2 & ...... do.. & Standing.- & .....do... & 5 & 5 & 100 \\
\hline Aug. 15 & do. & 2 & ..... do & ................. & .......do_... & 5 & 5 & 100 \\
\hline Oct. 17 & do. & 2 & ...... do. & ..... do .... & ..... do... & 5 & 5 & 100 \\
\hline July 15 & do & 4 & ...... do... & Cut off...... & ...... do do........ & 5 & 5 & 100 \\
\hline Aug. 15 & do. & 4 & ......do.. & .....do.... & ..... do... & 5 & 5 & 100 \\
\hline Oct. 17 & -do & 4 & ...... do... & ............... & ................. & 5 & 5 & 100 \\
\hline July 15 & do. & 4 & ......do.. & Standing. & ..... do... & 5 & 5 & 100 \\
\hline Aug. 15 & -do. & 4 & ......do.. & ...... do & & 5 & 5 & 100 \\
\hline Oct. 17 & do.. & 4 & -.... do.. & ..... do & do............ & 5 & 5 & 100 \\
\hline Total & & & & & & 90 & 84 & 83 \\
\hline
\end{tabular}

It is probable that an application of 2 quarts per bush would be a safe application to recommend for general use, aithough more trials should be made before any general recommendation is made.

Furfural is only very slightly soluble in water, and it is probable that the failure of 1 pint per bush to produce death in every case is due, to the poor distribution of the chemical in the soil. In all the experiments large quantities of dilute solutions have been more effective than small quantities of concentrated chemicals. If furfural could be diluted with some cheap liquid, thus increasing its volume without a corresponding increase in cost, it might be a very satisfactory herbicide, even at its present cost.

\section{PETROLEUM GAS OIL}

Petroleum gas oil is a distillation product of petroleum and is used in the manufacture of gas. It is a light oil with a kerosenelike odor, but is considerably heavier than kerosene. It was quoted at 7 cents a gallon; delivery charges would have to be added, however, thus considerably increasing the cost in the field.

No greenhouse tests were made with this material. The results of the field tests are shown in Table 12.

Table 12 shows that out of 153 bushes treated only 4 lired, and 3 of these were treated by applying the oil in a circle around the crown rather than as a drench directly around the base of the stalks of the plants. As none of the chemicals studied produced satisfactory results when applied in a circle around the bush, these two treatments need not be considered. It then appears that but 1 bush out of 113 survived, or that over 99 per cent mere killed. This places petroleum gas oil among the rery best chemicals studied, from the standpoint of effectiveness. It also ranks high from the standpoint of cost, but when availability is considered, this reduces its ranking. However, in a few localities it is readily available and should be given consideration. 
TABLE 12.-Summary of treatments of individual, marked barberry bushes with petroleum gas oil

\begin{tabular}{|c|c|c|c|c|c|c|c|c|}
\hline $\begin{array}{l}\text { Date of treat- } \\
\text { ment }\end{array}$ & $\begin{array}{l}\text { Date of final } \\
\text { observation }\end{array}$ & $\begin{array}{l}\text { Quan- } \\
\text { tity of } \\
\text { chemi- } \\
\text { cal per } \\
\text { bush }\end{array}$ & $\begin{array}{l}\text { Method of ap- } \\
\text { plication }\end{array}$ & $\begin{array}{l}\text { Bushes } \\
\text { cut off or } \\
\text { left stand- } \\
\text { ing }\end{array}$ & $\begin{array}{l}\text { Location of } \\
\text { area }\end{array}$ & $\begin{array}{l}\text { Bushes } \\
\text { treated }\end{array}$ & $\begin{array}{l}\text { Bushes } \\
\text { killed }\end{array}$ & $\begin{array}{l}\text { Per- } \\
\text { centage } \\
\text { killed }\end{array}$ \\
\hline A pr. 28,1922 & July $\quad 3,1923$ & $\begin{array}{c}\text { Gallons } \\
1.0\end{array}$ & In circle of 1- & Standing- & Gurnee, Ill. & 20 & 18 & 90 \\
\hline $\begin{array}{l}\mathrm{Do} \\
\text { Oct. } 8,1921\end{array}$ & June 29,1923 & $\begin{array}{l}1.0 \\
1.0\end{array}$ & Drench & $\begin{array}{l}\text { Cut off...- } \\
\text { Standing. }\end{array}$ & Black Earth, & $\begin{array}{l}20 \\
10\end{array}$ & $\begin{array}{l}19 \\
10\end{array}$ & $\begin{array}{r}95 \\
100\end{array}$ \\
\hline $\begin{array}{l}\text { Do } \\
\text { Oct. } 31,1921 \\
\text { July } 10,1922\end{array}$ & Juily 3,1923 & $\begin{array}{r}.5 \\
1.4 \\
1.0\end{array}$ & \begin{tabular}{l}
.... do do \\
\hdashline
\end{tabular} & $\begin{array}{l}\text { Cut off...- } \\
\text { Standing. }\end{array}$ & $\begin{array}{l}\text { Wis. } \\
\text { Gurnee, ili.: } \\
\end{array}$ & $\begin{array}{l}20 \\
36 \\
20\end{array}$ & $\begin{array}{l}20 \\
36 \\
20\end{array}$ & $\begin{array}{l}100 \\
100 \\
100\end{array}$ \\
\hline Oct. 16,1922 & -...-do & $\begin{array}{l}1.0 \\
1.0\end{array}$ & -...do do & $\begin{array}{l}\text { Cut off.-. } \\
\text { Standing. }\end{array}$ & 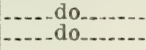 & $\begin{array}{r}20 \\
7\end{array}$ & $\begin{array}{r}19 \\
7\end{array}$ & $\begin{array}{r}95 \\
100\end{array}$ \\
\hline Total . & & & & & & 153 & 149 & 97 \\
\hline
\end{tabular}

\section{GASOLINE}

Gasoline tried on potted barberries killed the plants in two weeks when 21 cubic centimeters was applied to the surface of the soil. The action was slow, but death finally resulted. Twenty-one cubic centimeters applied to an 8-inch pot is the equivalent of about 0.5 gallon in the field. At about 11 cents a gallon the price was very satisfactory, and it was thought worth while to make further tests. The results of field tests, given in Table 13, justify this decision.

TABLE 13.-Summary of treatments of individual, marked barberry bushes with gasoline

\begin{tabular}{|c|c|c|c|c|c|c|c|c|}
\hline $\begin{array}{c}\text { Date of } \\
\text { treatment }\end{array}$ & $\begin{array}{l}\text { Date of final } \\
\text { observation }\end{array}$ & $\begin{array}{l}\text { Quantity } \\
\text { of chem- } \\
\text { ical per } \\
\text { bush }\end{array}$ & $\begin{array}{l}\text { Method of } \\
\text { application }\end{array}$ & $\begin{array}{l}\text { Bushes } \\
\text { cut off } \\
\text { or left } \\
\text { standing }\end{array}$ & $\begin{array}{c}\text { Location of } \\
\text { area }\end{array}$ & $\begin{array}{l}\text { Bushes } \\
\text { treated }\end{array}$ & $\begin{array}{l}\text { Bushes } \\
\text { killed }\end{array}$ & $\begin{array}{l}\text { Per- } \\
\text { centage } \\
\text { killed }\end{array}$ \\
\hline 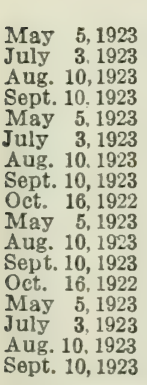 & 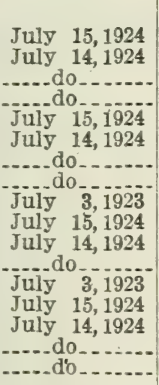 & $\begin{array}{r}\text { Gallons } \\
0.5 \\
.5 \\
.5 \\
.5 \\
.5 \\
.5 \\
.5 \\
.5 \\
1.0 \\
1.0 \\
1.0 \\
1.0 \\
1.0 \\
1.0 \\
1.0 \\
1.0 \\
1.0\end{array}$ & \begin{tabular}{|l} 
Drench \\
$\ldots$ do \\
- do \\
$\ldots$ do
\end{tabular} & 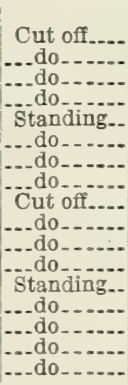 & \begin{tabular}{|c|} 
\\
Gurnee, Ill... \\
\\
\hdashline \\
\\
\hdashline
\end{tabular} & $\begin{array}{r}10 \\
7 \\
10 \\
5 \\
8 \\
7 \\
10 \\
5 \\
20 \\
10 \\
10 \\
5 \\
20 \\
10 \\
10 \\
10 \\
5\end{array}$ & $\begin{array}{r}8 \\
7 \\
3 \\
5 \\
8 \\
4 \\
10 \\
5 \\
20 \\
10 \\
10 \\
5 \\
20 \\
10 \\
7 \\
10 \\
5\end{array}$ & $\begin{array}{r}80 \\
100 \\
30 \\
100 \\
100 \\
57 \\
100 \\
100 \\
100 \\
100 \\
100 \\
100 \\
100 \\
100 \\
70 \\
100 \\
100\end{array}$ \\
\hline Tota & & & & & & 162 & 147 & 91 \\
\hline
\end{tabular}

In the study of other chemicals it had been determined that an application was most effective in killing a barberry bush when applied as a drench to the ground among and around the bases of all shoots of the plant. This method was, therefore, followed with gasoline. The unknown point was the quantity necessary to kill a bush of given size and whether this would be equally effective at 
all seasons of the year. An examination of the results given in Table 13 shows that when only one-half gallon of gasoline was used per bush about 19 per cent of the bushes were not entirely killed. Even with an application of 1 gallon per bush 3 per cent lived.

Merely from the standpoint of effectiveness gasoline was very satisfactory. No doubt a slightly larger application would be 100 . per cent effective, but considering cost, even an application of 1 gallon per bush was too expensive. Other chemicals were much cheaper and were equally as available as well as more effective.

\section{KEROSENE}

Kerosene was tried on potted barberries growing in the greenhouse. Doses as large as 42 cubic centimeters applied to the surface of the soil in 8-inch pots failed to cause appreciable injury to the barberries growing therein. This dose was estimated to be the equivalent of about 1 gallon applied to a bush in the field. This result was surprising, because kerosene has been much used as a herbicide and is known to be very injurious to many plants.

Had it not been for the fact that J. W. Baringer, associate pathologist in the Bureau of Plant Industry, United States Department of Agriculture, in charge of the barberry-eradication campaign in Ohio, reported an instance where barberries which he had treated with kerosene were dead the following year, experiments with either kerosene or gasoline might not have been continued. A number of field treatments were made, with the results noted in Table 14.

TABLE 14.-Summary of treatments of individual, marked barberry bushes with kerosene

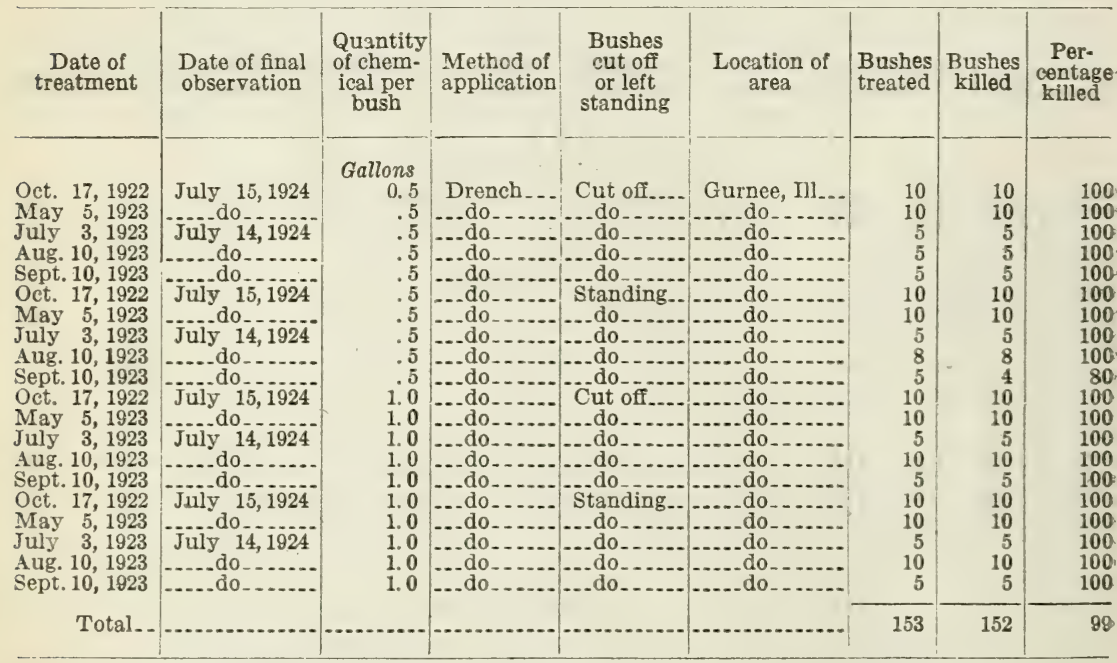

An examination of Table 14 shows that out of 153 bushes treated only 1 lived. This bush was treated in September with one-half gallon of kerosene. These treatments averaged over 99 per cent effective, making the best showing of all the more extensive ones. Even salt, which is perhaps the most satisfactory chemical for kill- 
sng barberries, did not make so good an average record. The reason for this is evident. The field treatments with kerosene were not begun until late in the fall of 1922 . By that time the character of the root system of the barberry and the most effective point of application of chemicals had been determined. A rather definite idea as to the quantity of chemical necessary to kill barberries also had ibeen acquired.

One feature in connection with the use of kerosene for killing barberries which is not shown in Table 14 is the speed of the action of the chemical. In the greenhouse the experiments ran for about one month, at the end of which time there was no apparent injury to the plants, yet kerosene is one of the most effective chemicals known for killing barberries. In the field, kerosene is equally slow in its action. For instance, of the 20 bushes treated on May $\breve{5}$ only 1 showed more than slight injury on July 3, but by October all of these bushes were dead.

The bushes treated July 3, 1923, were examined on August 10, at which time one of the five receiving 1 gallon was recorded as dead. The other four and the five receiving only one-half gallon showed from slight to no injury. On September 20, of the fire receiving 1 gallon each, three were recorded as dead and two had still a few green leaves. The notes on the bushes receiving one-half gallon are as follows: "One small bush looks dead. The other four have dropped most of their leaves but retain a few green ones. One of them shows new growth from some buds." However, on July 14, 1924 , all 10 of these bushes were dead.

Another interesting feature was observed in several instances. 'The rata for the treatments made October 17, 1922, will illustrate it. On that date 10 standing bushes were treated with one-half gallon of kerosene each. On May 4, 1923, they were examined and the following notes were made: "Three plants without leaves. The others : 11 have from a few to many leaves. They are not as far advanced as untreated bushes." By July 3 all this new growth had died, and later examination showed that all the bushes were dead.

These instances show that kerosene is very slow in its action on barberries. In some ways this is a serious disadvantage and makes this chemical less desirable to use for eradication purposes than a rapidly acting chemical such as salt. It also is evident that brief greenhouse tests can not be taken as an absolute criterion of the action of any chemical in the field. Greenhouse tests undoubtedly are of value at times as indicators, but too much reliance should not be placed on them.

The results with kerosene were so satisfactory and results obtained by Baringer in Ohio corroborated them so well, that in the spring of 1924 the use of this chemical for eradicating barberries was recommended. A circular (16) published by the United States Department of Agriculture gives in detail the method of using this substance. As a result, several thousand barberry bushes have been treated with kerosene with uniformly satisfactory results.

It is interesting to compare the four petroleum oils studied-gasoline, gas o:l, kerosene, and fuel oil. All were very slow in their action. Gasoline was perhaps a little more rapid than the others, but it was slightly less effective than either kerosene or gas oil. The 
fuel oil was the least effective of all, probably because of its failure to penetrate the soil readily.

Considering all the oils studied, it was found that in general the lighter, more penetrating oils were more effective than the heavier ones. For this reason gasoline might have been expected to be the most effective of the four petroleum oils studied. Why it was not is not known.

\section{MONOCHLOROBENZENE}

Monochlorobenzene $\left(\mathrm{C}_{6} \mathrm{H}_{5} \mathrm{Cl}\right)$ also is a light liquid and is obtainable in quantity for about 12 cents a pound. Eight cubic centimeters sufficed to kill barberries in 8-inch pots in 22 days. No field tests were made.

\section{NITROBENZENE}

Nitrobenzene $\left(\mathrm{C}_{6} \mathrm{H}_{5} \mathrm{NO}_{2}\right)$, a light liquid, was quoted at 11.5 cents a pound in 1,000-pound lots. When applied to the soil of 8-inch pots in which barberries were growing, 5.2 cubic centimeters caused their death in 20 days. This was a slightly better showing than was made by any of the other benzol compounds, with the exception of phenol and orthotoluidine. No field tests were made.

\section{PARANITROCHLOROBENZENE}

Paranitrochlorobenzene $\left(\mathrm{C}_{6} \mathrm{H}_{4} \mathrm{NO}_{2} \mathrm{Cl}\right)$ is a liquid at ordinary temperature. When 5.2 cubic centimeters of it were applied to the soil around barberries growing in 8-inch pots death of the plants resulted in about six weeks. As the action was so slow and the chemical somewhat expensive, no field tests were made.

\section{ORTHONITROTOLUENE}

Orthonitrotoluene $\left(\mathrm{C}_{6} \mathrm{H}_{4} \mathrm{CH}_{3} \mathrm{NO}_{2}\right)$ is an oily liquid. Five cubic centimeters applied to the soil in 8-inch pots in which barberries were growing caused the death of the plants in about seven weeks. As larger doses would be too expensive no further tests were made with this chemical.

\section{PARATOLUENEMONOSULPHONIC ACID}

Paratoluenemonosulphonic acid $\left(\mathrm{C}_{6} \mathrm{H}_{4} \mathrm{CH}_{3} \mathrm{HSO}_{3} .4 \mathrm{H}_{2} \mathrm{O}\right)$ is a crystalline substance. It was quoted at 30 cents a pound in 1,000-pound lots. A treatment of 5.2 grams applied to barberries in 8 -inch pots failed to kill the plants. Some of the lower leares died, however. No field tests were made.

\section{PARATOLUENESODIUMSULPHONATE}

Paratoluenesodiumsulphonate $\left(\mathrm{C}_{6} \mathrm{H}_{4} \mathrm{CH}_{3} \mathrm{SO}_{3} \mathrm{Na}\right)$ is a crystalline substance quoted at about 10 cents a pound in 1,000-pound lots. Then applied to barberries in 8 -inch pots 10 grams failed to kill the plants, though there was slight injury. No field tests were made. 


\section{PARATOLUENESULPHOCHLORIDE}

When paratoluenesulphochloride $\left(\mathrm{C}_{6} \mathrm{H}_{4} \mathrm{CH}_{3} \mathrm{SO}_{2} \mathrm{Cl}\right)$ was applied to the soil in 8-inch pots in which barberries were growing, 5.2 grams per pot failed to cause the death of the barberries, though a slight injury to a few leaves resulted. No field tests were made.

\section{ORTHOTOLUIDINE}

Orthotoluidine $\left(\mathrm{C}_{6} \mathrm{H}_{4} \mathrm{CH}_{3} \mathrm{NH}_{2}\right)$ is a light. oily liquid. It was quoted at 15 cents a pound in 2,000-pound lots.

In greenhouse tests 2 cubic centimeters caused barberries growing in 8-inch pots to die after three days. This was the best showing made by any of the chemicals tried in the greenhouse. An application of 2 cubic centimeters to an 8-inch pot was considered the equivalent of 0.4 of a pint applied to a mid-sized bush in the field. However, in the field tests with this chemical the minimum dosage given a barberry was 1 pint.

Table 15 gives the results of the field tests with orthotoluidine.

TABLE 15.-Summary of treatments of individual, marked barberry bushes with orthotoluidine

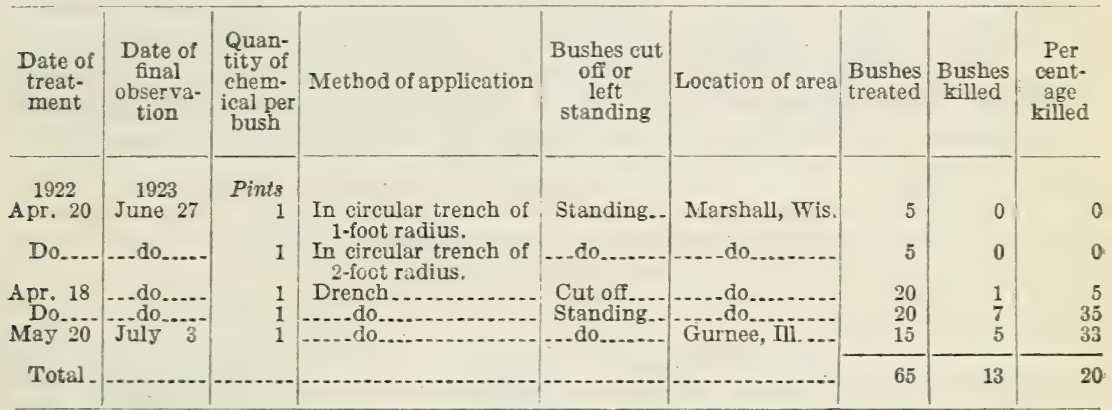

As was found to be the case with other chemicals tested, the most satisfactory method of application was as a drench immediately around the base of the shoots. Even with this method of application, howerer, the results were far from satisfactory. With sodium arsenite and sodium dichromate it was found necessary to use a fairly large volume of solution-that is, from 1 to 2 gallons per bush-to obtain uniformly successful treatments. Had it been possible to dilute the orthotoluidine in some way without additional expense the results might hare been more successful. Since the chemical is insoluble in water, the cost of diluting it, no doubt, would have been considerable.

The results with orthotoluidine also demonstrate the dangers of drawing too definite conclusions from the results of greenhouse tests with herbicides. This chemical was among the most effective in the greenhouse, whereas in the field it was very ineffective. On the other hand, kerosene did not appear at all satisfactory when tried on potted plants, but it is one of the two or three most satisfactory in the field. 


\section{PARATOLUIDINE}

Paratoluidine $\left(\mathrm{C}_{6} \mathrm{H}_{4} \mathrm{CH}_{3} \mathrm{NH}_{2}\right)$ is a white crystalline substance. Applied to the soil in 8-inch pots in which barberries were growing, 5.2 grams failed to cause the death of the plants in 30 days, though most of the leaves died. The action was much slower than that of orthotoluidine. Therefore, field tests were not made with this substance.

\section{WATER-GAS DRIP OIL}

Water-gas drip oil is a substance of rarying composition and consistency, which condenses in gas mains and is caught in "drip pots" whence it is removed. In most cases no use is made of the drip oil, and it is disposed of in the least offensive way. It can be purchased from gas companies at about the cost of handling.

The water-gas drip oil used in these experiments was a thin watery liquid, almost black in color, with a strong, somewhat unpleasant, and very persistent odor. Some companies refer to thick liquids as drip oil. The substance used is said to consist of benzol, toluol, xylol, and higher homologues of the benzene series, napthalene, tarry residues, water, very small quantities of ammonium chloride, sulphur, and unsaturated hydrocarbons of the ethylene and acetylene series.

Quantities of this drip oil were obtained from several local gas companies at a cost, including the barrels, of about 10 cents a gallon.

In the greenhouse an application of 80 cubic centimeters of watergas drip oil to a barberry growing in an 8-inch pot killed the plant in 21 days. Field tests also were made, the results of which are given in Table 16.

TABLE 16.-Summary of treatments of individual, markcd barberry bushes uith water-gas drip oil

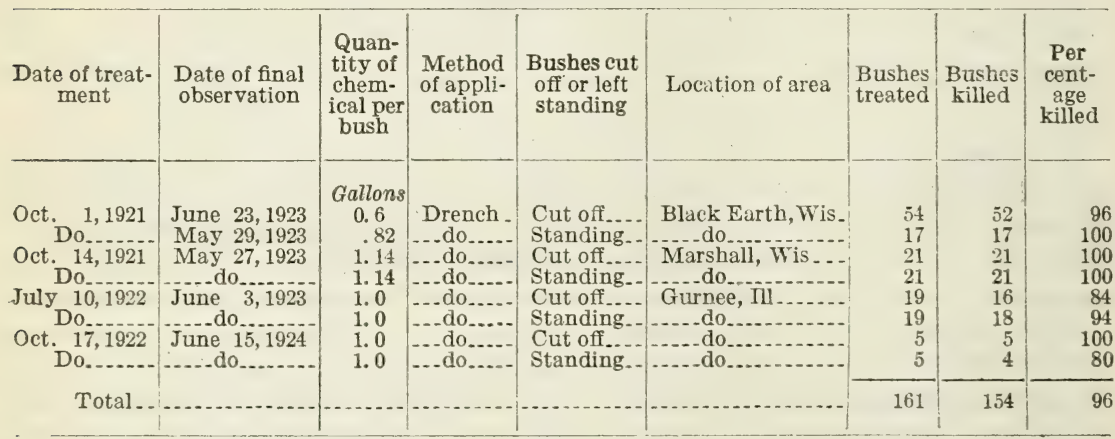

Though treatments were made only in July and October and the quantities used were not varied greatly, the results were very promising. From these limited tests it would seem that, considering merely cost and effectiveness, drip oil would rank well toward the top of all the chemicals tried on barberries in the field. There are several disadvantages, however, in its use for barberry eradication in an extensive way. First, it is of unknown and varying constitution. Drip oils obtained from different gas plants would vary to some extent, and the action of a specific one on barberries could be 
determined only by trial. Second, it is difficult to obtain locally in quantity and at short notice. To obtain a sufficient quantity to treat several hundreds or perhaps thousands of barberries would necessitate waiting until enough accumulated in the mains. Third, the odor of drip oil is very persistent and will remain for many months about the spot to which the oil is applied.

\section{WATER-GAS TAR}

Water-gas tar is a heavy residue in the manufacture of water gas. It was obtained locally at 5 cents a gallon. No greenhouse tests were made, but there were a number of field trials.

An application of 0.8 gallon of water-gas tar was made to each of 12 standing barberry bushes on October 1, 1921. In July, 1923, only 3 of these bushes were dead. An application of 0.7 of a gallon was made to each of 18 barberries on the same date. These bushes previously had been cut down. All were alive in July, 1923.

Water-gas tar is a black, viscid, ill-smelling liquid that is very disagreeable to handle. It scarcely penetrates the ground but cakes and remains on the surface. The shoots and roots of the barberries that were touched by the chemical were killed, but the lateral roots were healthy outside the area to which the tar was applied, and many sprouts arose from them. It would seem that these roots are capable of sprouting to some extent even if undisturbed when the crown of the bush is killed, unless the killing agent is a chemical which penetrates the roots.

The results of these tests with water-gas tar do not justify any further experiments with this substance.

\section{SUMMARY OF CHEMICALS STUDIED}

In the foregoing pages the results obtained by treating barberry plants with each of 37 different chemicals are reported. It is possible that some of the other chemicals might be satisfactory if the best method of application was determined by more extensive study. This is illustrated by experiments with kerosene, which proved ineffective in the greenhouse trials yet were very satisfactory in the field. This is further shown in experiments with a concentrated sodium-arsenite solution and crystals of sodium dichromate which were ineffective, while dilute solutions of both proved effective killing agents. Time was a very important item, as hundreds of thousands of dollars were being spent annually in barberry eradication, much of which was being wasted by ineffective methods. A delay of a year in reaching a practical solution of the problem of successful eradication would have resulted in a very considerable loss. Therefore, efforts were concentrated on those chemicals which gave the most promise in the earlier studies.

Although the results are fragmentary and incomplete, they throw some light on what may be expected of different types of chemicals when used to kill barberries or other plants. The character and distribution of the roots in the soil are all important in the case of plants that sprout readily from the crown and roots and therefore are not easily killed by sprays or by other methods that merely kill the tops. To kill such plants with a chemical, it is necessary to apply 
the latter so that it will reach the fine roots of the plant and be readily absorbed by them. It is essential, therefore, to know where these roots are located. As has been said, the barberry, while having a large spreading root system, also produces an abundance of fine feeding roots immediately around the base of the shoots. It was found that if a chemical was applied so as to reach these roots the death of the plant was likely to occur. It also was found that, while all the shoots of a bush might be connected by stolons, they were independent to the extent that in order to insure the death of all of them each must receive a portion of the chemical.

\section{TABLE 17.-Comparison of the 10 best chemicals used for killing barberries}

[Words set in italic indicate a favorable result or condition]

\begin{tabular}{|c|c|c|c|c|c|c|c|}
\hline Chemical & $\begin{array}{l}\text { Quantity } \\
\text { producing } \\
\text { results given }\end{array}$ & $\begin{array}{l}\text { Per- } \\
\text { cent- } \\
\text { age of } \\
\text { bushes } \\
\text { killed }\end{array}$ & $\begin{array}{l}\text { Approximate } \\
\text { cost of dose } \\
\text { per bush }\end{array}$ & $\begin{array}{l}\text { Avail- } \\
\text { ability }\end{array}$ & $\begin{array}{l}\text { Ease of } \\
\text { handling }\end{array}$ & Safety & Remarks \\
\hline $\begin{array}{l}\text { Sodium chlo- } \\
\text { ride. } \\
\text { Kerosene...... }\end{array}$ & $\begin{array}{l}10 \text { pounds } \\
\text { dry. } \\
1 \text { gallon..... }\end{array}$ & $\begin{array}{l}100 \\
100\end{array}$ & $\begin{array}{l}10 \text { cents de- } \\
\text { livered. } \\
13 \text { cents de- }\end{array}$ & Excellent. & $\begin{array}{l}\text { Satisfactory. } \\
\text { do............ }\end{array}$ & $\begin{array}{l}\text { Excellent. } \\
\text {....do..... }\end{array}$ & Action slow. \\
\hline $\begin{array}{l}\text { Sodium arse- } \\
\text { nite. } \\
\text { Sodium di- } \\
\text { chromate. }\end{array}$ & $\begin{array}{l}0.4 \text { pint in } \\
\text { solution. } \\
1 \text { pound in } \\
\text { solution. }\end{array}$ & 100 & 8 cents $f .0 . b$. & $\begin{array}{l}\text { Fair.. } \\
\text {...do.. }\end{array}$ & ......................... & $\begin{array}{l}\text { Very pois- } \\
\text { onous. } \\
\text { Excellent.... }\end{array}$ & Not suffi- \\
\hline $\begin{array}{l}\text { Calcium chlo- } \\
\text { ride. }\end{array}$ & $\begin{array}{l}15 \text { pounds } \\
\text { dry. }\end{array}$ & 90 & 24 cents f.o.b & ...do... & Disagreeable & ....do... & ed. \\
\hline $\begin{array}{l}\text { Furfural....... } \\
\text { Gasoline...... }\end{array}$ & 1 quart........ & $\begin{array}{r}100 \\
97\end{array}$ & $\begin{array}{l}9 \text { cents } f .0 . b- \\
23 \text { cents de- }\end{array}$ & $\begin{array}{l}\text { Poor..... } \\
\text { Excellent.. }\end{array}$ & Satisfactory.- & Fire hazard. & $\begin{array}{l}\text { Do. } \\
\text { Action slow. }\end{array}$ \\
\hline $\begin{array}{l}\text { Petroleum- } \\
\text { gas oil. }\end{array}$ & ...... do......... & 96 & 7 cents $f .0 . b$. & Fair... & ......do......... & Excellent.... & \\
\hline $\begin{array}{l}\text { Phenol, } 15 \text { per } \\
\text { cent crude. }\end{array}$ & ......do... & 100 & 35 cents f.o.b. & ...do....... & $\begin{array}{c}\text { Di s agree- } \\
\text { able. }\end{array}$ & Corrosive... & Not suffi- \\
\hline $\begin{array}{l}\text { W a t e r-g as } \\
\text { drip oil. }\end{array}$ & ................... & 90 & 10 cents f.o.b. & Poor..... & $\begin{array}{l}\text { Very dis- } \\
\text { agreeable. }\end{array}$ & Excellent.... & \\
\hline
\end{tabular}

On the basis of effectiveness in killing common barberries, a few generalizations may be made from the studies of the chemicals here reported.

1. Sufficient chemical or solution must be applied so that the fibrous roots around the base of every shoot will receive a lethal dose.

2. Gas-forming substances generally fail to give uniformly satisfactory results, probably because of irregularities in the permeability of the soil around a bush.

3. Heavy oils and tarry substances fail to produce general killing, probably because of their failure to penetrate the soil to a sufficient extent or the failure of the roots to absorb them.

4. Light oils, on the other hand, are fairly satisfactory.

5. Inorganic salts are very satisfactory when applied in sufficient quantity to reach all the fibrous roots around the base of the shoots.

Five criteria of a satisfactory chemical for barberry eradication were established. In the order of their importance these are: Effectiveness, cost, availability, ease of handling, and safety. In Table 17 the 10 best chemicals are compared on this basis. When a chemical was satisfactory in any particular, in making up the table that item was put in italics. 
It is evident that sodium chloride and kerosene are the most generally satisfactory in this group. Salt is somewhat cheaper than kerosene, and as its action is much more rapid it is the first choice. Kerosene is second. Sodium dichromate would appear to be third; however, it took so long to determine the most effective method of using this substance that sufficient field trials were not made. Therefore, sodium-arsenite solution is placed third in the list. The writers are in doubt as to the order in which the remaining chemicals should be placed.

\section{GENERAL SUMMARY}

The common barberry (Berberis vulgaris L.) is an introduced ornamental shrub occurring extensively throughout a large part of the eastern and north-central United States. The bush grows readily from seed; having escaped from cultivation, it becomes restablished in pasture lands, in open wood lots, and along fence rows.

The seeds are distributed chiefly by birds and by browsing cattle.

The bush develops a crown which gives off horizontal rhizomes, numerous large, mostly horizontal roots, and a mass of fine fibrous roots. Small fragments of either the horizontal roots or rhizomes may grow and produce sprouts.

In the course of the barberry-eradication campaign it was discovered that the results of grubbing were not altogether satisfactory, that many sprouts appeared from dug bushes, necessitating inspection a second and third time, and that there were large areas of escaped bushes in situations where digging was difficult and where reinspection was expensive. As a result of these developments, a study of methods of destroying the barberry was initiated.

The following mechanical methods have been employed in eradicating barberry bushes: Grubbing, burning, cutting off at ground line, and grazing.

These methods have included the use of the grub hoe, of teams and tractors, and of dynamite. The method selected depends upon the number of bushes to be destroyed, the size of the bushes, the type of soil, the season, and the means available. In any case it is essential that all roots be removed from the soil.

All grubbed bushes should be burned, in order to prevent the possibility of their taking root and growing again where they were left, and also to destroy any seeds on the bushes.

The cost of grubbing barberries varies widely.

The barberry can not be eradicated by occasionally cutting it down to the ground.

Grazing by animals apparently does not prevent the growth of the barberry. The plants can not be destroyed by cutting them down and burning the tops, with or without straw, on the crown.

A satisfactory chemical for use in eradicating the common barberry must be (1) effective, (2) readily available, (3) cheaper than equally effective grubbing, (4) easy to handle, and (5) of little or no danger to those handling it, to persons or animals having access to it, and to useful vegetation or to soil.

The experiments with chemicals included trials on small potted barberries in the greenhouse and field treatments. The latter were 
of two kinds: (1) Treatment of individual, marked barberry bushes with different chemicals; and (2) treatment of all the barberries growing in a certain area with one chemical.

Experiments with 37 different chemicals are reported. These included (1) inorganic salts, (2) acids and acid formers, (3) gasforming substances, and (4) oils and other organic substances.

In the use of solutions the best results followed the application of the chemical as a drench about the base of the plant, whereas with dry substances, such as salt, best results were obtained by piling it in the base. Although all the shoots of an individual bush may be connected by stolons, each must receive a portion of the chemical in order to insure the death of all. Gas-forming substances and heavy oils failed to give uniformly satisfactory results.

All factors considered, common salt (sodium chloride) proved to be the most satisfactory chemical for killing the common barberry. Kerosene and sodium arsenite in solution rank second and third, respectively.

Sodium arsenite, although very effective, is extremely poisonous to livestock. Because of this danger it is not recommended for general use. 


\section{LITERATURE CITED}

(1) Blakeslee, E. B.

1919. USE OF TOXIC GASES AS A POSSIBLE MEANS OF CONTROL OF THE PEACH-TREe bORER. U. S. Dept. Agr. Bul. 796, 23 pp., illus.

(2) Bolley, H. L.

1900. investigations on weeds. N. Dak. Agr. Exp. Sta. Rpt. 1889, pp. $25-28$.

(3) Brown, B. E.

1922. EFFECT OF BORAX IN FERTILIZER ON THE GROWTH AND YIELD OF ротатоes. U. S. Dept. Agr. Bul. 998, 8 pp., illus.

(4) Dusserre, C.

1899. DESTRUCTION DES MAUVAISES HERBES PAR LES SUBSTANCES CHIMIQUES. Chron. Agr. Canton Vaud, ann. 12, pp. 265-268.

(5) Guyton, T. L., and Stear, J. R.

1924. PDB (PARADICHLOROBENZENE) AND OTHER CONTROLS FOR THE PEACHTREe BORER. Pa. Dept. Agr. Gen. Bul. 383, 10 pp., illus.

(6) Hinds, W. E.

1917. CARbon disulphid as an insecticide. U. S. Dept. Agr. Farmers' Bul. 799, $21 \mathrm{pp}$.

(7) Jones, L. R., and Orton, W. A.

1897. ORANGE HAWKWEED OR "PAINT-BRUSh." Vt. Agr. Exp. Sta. Bul. $56,16 \mathrm{pp}$.

1899. killing weeds with chemicals. Vt. Agr. Exp. Sta. Rpt. 1898-99, pp. 182-188.

(9) LIND, J.

1915. BERBERISBUSKEN OG BERBERISLOVEN. Tidsskr. Planteavl., Bd. 22 , pp. $729-780$.

(10) Potтs, H. W.

1902. A BRIER AND BLACKBERRY BUSH eRAdiCATOR. Jour. Dept. Agr. Victoria, vol. 1, p. 27.

(11) RUDOLFs, W.

1920. EXPERIMENTS ON THE VALUE OF COMMON ROCK SALT AND SULPHUR FOR KILliNG LIVE stUmps. Soil Sci., vol. 9, pp. 181-189, illus.

(12) Rumbold, C.

1920. THe injection of Chemicals into chestnut trees. Amer. Jour. Bot., vol. 7, pp. 1-20, illus.

(13) 1920. EFFECT ON CHESTNUTS OF SUBSTANCES INJECTED INTO THEIR TRUNKs. Amer. Jour. Bot., vol. 7, pp. 45-56, illus.

(14) Schulz, E. R., and Thомpson, N. F.

1925. SOME EFFECTS OF SODIUM ARSENITE WHEN USED TO KILL THE COMMON barberRy. U. S. Dept. Agr. Bul. 1316, 19 pp., illus.

(15) Tномpson, N. F.

1923. Kill the common barberRy with chemicals. U. S. Dept. Agr. Circ. 268, 4 pp., illus.

(16) 1924. CHEMiCal ERAdication OF the COMMON BARBERRY. U. S. Dept. Agr. Circ. 332, 4 pp.

(17) VALDER, G.

1902. the eradication of PRICkly pears. Agr. Gaz. N. S. Wales, vol. 13 , pp. 59-62, illus.

(18) Wilcox, E. V.

1909. CARBon Bisulphid for killing weeds. Hawaii Agr. Exp. Sta. Press Bul. 25, 4 pp. 


\title{
ORGANIZATION OF THE UNITED STATES DEPARTMENT OF AGRICULTURE
}

November 23, 1926

\begin{abstract}
Secretary of Agriculture
Assistant Secretary__-_._._._. R. W. Dunlap.

Director of Scientific Work__._._._. Woods.

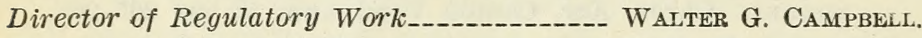

Director of Extension Work.............. C. W. WARBURTON.

Director of Information_..........-. NELSON ANTRIM CRAWFORD.

Director of Personnel and Business $A d$ ministration

Solicitor

W. W. STOCKBerger.

Weather

R. W. WILliams.

Bureau of Agricultural Economics

Charles F. Marvin, Chief.

Bureau of Animal Industry

Lloyd S. TENNy, Acting Chiet.

Bureau of Plant Industry John R. Mohler, Chief.

Forest Service William A. Taylor, Chief.

Bureau of Chemistry W. B. Greetey, Chief.

Bureau of Soils C. A. Browne, Chief.

Bureau of Entomology MrLton Whitney, Chief.

Bureau of Biological Survey L. O. How ARD, Chief. Bureau of Public Roads. E. W. Nelson, Chief.

Bureau of Home Economics Thomas H. MacDonald, Chief.

Bureau of Dairy Industry Louise Stanley, Chief.

Office of Experiment Stations C. W. Larson, Chief.

Office of Cooperative Extension Work E. W. Allen, Chief. Library C. B. Sмiтh, Chief.

Federal Horticultural Board Claribel R. Barnett, Librarian. Insecticide and Fungicide Board C. L. MaRLATt, Chairman. -- J. K. HaYwood, Chairman. Packers and Stockyards Administration ... JоHN T. CAINE III, in Charge. Grain Futures Administration J. W. T. Duver, in Charge.
\end{abstract}

This bulletin is a contribution from

Bureau of Plant Industry WILliam A. TAYLor, Chief.

Office of Cereal Crops and Diseases_-- CARLETON R. BALL, Senior Agrono. mist, in Charge. 
